\title{
WestVirginiaUniversity
}

THE RESEARCH REPOSITORY @ WVU

Graduate Theses, Dissertations, and Problem Reports

2002

\section{Explaining Viking expansion}

Darrin M. Cox

West Virginia University

Follow this and additional works at: https://researchrepository.wvu.edu/etd

\section{Recommended Citation}

Cox, Darrin M., "Explaining Viking expansion" (2002). Graduate Theses, Dissertations, and Problem Reports. 819.

https://researchrepository.wvu.edu/etd/819

This Thesis is protected by copyright and/or related rights. It has been brought to you by the The Research Repository @WVU with permission from the rights-holder(s). You are free to use this Thesis in any way that is permitted by the copyright and related rights legislation that applies to your use. For other uses you must obtain permission from the rights-holder(s) directly, unless additional rights are indicated by a Creative Commons license in the record and/ or on the work itself. This Thesis has been accepted for inclusion in WVU Graduate Theses, Dissertations, and Problem Reports collection by an authorized administrator of The Research Repository @ WVU. For more information, please contact researchrepository@mail.wvu.edu. 


\title{
Explaining Viking Expansion
}

\author{
Darrin M. Cox
}

\author{
Thesis submitted to the \\ College of Arts and Sciences \\ at West Virginia University \\ in partial fulfillment of the requirements \\ for the degree of
}

\author{
Master of Arts \\ in \\ Medieval History
}

Stephen McCluskey, Ph.D., Chair Patrick Conner, Ph.D.

Matthew Vester, Ph.D.

Department of History

\section{Morgantown, West Virginia 2002}

Keywords: Viking, expansion Copyright 2002 Darrin M. Cox 


\title{
Abstract \\ Explaining Viking Expansion
}

\author{
Darrin M. Cox
}

Current scholarship regarding Scandinavia has neglected to give all but a cursory glance at the factors involved in Viking expansion. This thesis studies and explains employment opportunities, political motives, and societal norms as separate, individual motives that perpetuated Scandinavian migration, conquest, and adventure from the eighth through the eleventh centuries AD. Afterwards, these investigations are used to describe the various and sometimes conflicting forces of expansion that led to the formation of the Danelaw in England circa AD 870. Over time, the eventual adoption of Christianity and feudal relationships within Scandinavia would bring expansion as well as the Viking Age to a close. 
This thesis is dedicated:

to my lovely wife, Karen, whose love, support, and attempts at gravy kept me focused on the task at hand,

to my friends, who provided much needed distractions from it, and to my parents, whose patience and understanding finally paid off. 


\section{Acknowledgements:}

I would initially like to thank the Interlibrary Loan Department in the West Virginia University Libraries for their invaluable assistance in tracking down the numerous sources used in the completion of this project. The National Geophysical data Center, NOAA Satellites and Data, provided the coastal outlines for the maps. Ginger Bernholt provided additional Geographic Information Systems (GIS) input for the location of cities and coastal outlines. I would also like to thank my committee members, Dr. Stephen McCluskey, Dr. Matt Vester, and Dr. Patrick Conner, for their guidance throughout not only this thesis, but also throughout my years here at WVU. In addition, thanks to the members of Vestgard, a Viking re-enactment group from Morgantown, West Virginia, for acting as a sounding board for many of the ideas expressed within. Lastly, many thanks go to my wife Karen and my family for their continued love and support. 


\section{Table of Contents}

Introduction 1

Chapter One: Employment Opportunity 19

Section One: Trade 19

Economic Community Before AD 800

Mercantile Tactics 42

The Continuation of Trade After the Onset of Violence 51

Section Two: Mercenary Employment 64

Scandinavian Employers $\quad 65$

Christian Employers of Medieval Europe $\quad 69$

The Byzantine Empire $\quad 73$

$\begin{array}{ll}\text { Chapter Two: Politics and Society } & 77\end{array}$

Section One: Political Agendas 77

Conquest $\quad 79$

Forcible Insertion $\quad 87$

Financing Internal Conflict $\quad 90$

Consolidation of Power 98

Section Two: Societal Influences 101

Religion 102

Outlawry and Necessity 104

Polygamy and Inheritance 108

Norms and Expectations 112

$\begin{array}{ll}\text { Chapter Three: Analysis of Expansion } & 116\end{array}$

$\begin{array}{ll}\text { Chapter Four: Waning of Viking Expansion } & 128\end{array}$

$\begin{array}{ll}\text { Bibliography } & 136\end{array}$ 


\section{List of Maps}

Major Ports of the Baltic Sea 29

Major Ports of the North Sea 36

Russian Princedoms 45 


\section{$\underline{\text { Introduction }}$}

Modern conventions of history dictate that the Viking Age began with the infamous raid of the Lisdisfarne monastery in AD 793 as reported in the Anglo-Saxon Chronicle. This event signaled the starting point of a time when "heathen" men from the north, who over time became collectively known as "Vikings," suddenly spilled into the world, launching a three hundred year barrage of devastation on the towns, countryside, and religious centers of medieval Europe. This age lasted until AD 1066, when Harald Godwinson defeated Norwegian King Harald Hardrada at the Battle of Stamford Bridge. Viking influence, whether for good or evil, spread from their homelands in Scandinavia, across the North Atlantic, through the Carolingian Empire, down the rivers of modern day Russia, and into the Byzantine Empire.

The image of the Viking has changed considerably over the years however. Due largely to the acknowledgement of recent scholarship that Scandinavians were the first Europeans to set foot on the North American continent, Viking studies have become increasingly popular in America. These investigations are revealing that Scandinavians were also traders, politicians, farmers, and adventurers instead of just the savage, bloodthirsty thieves reported in contemporary Christian documents. However, while these studies have managed to reverse a good deal of the negative press levied against the 
Vikings by writers of the time, surprisingly little work has been done to document why Scandinavians were pushing out beyond their boundaries to such a great extent and why it happened so rapidly. Unfortunately, when researchers do give explanations, they are brief and mentioned only in passing.

This work is an attempt to identify and combine as many of the relative factors of Viking expansion as possible together into one cohesive work so as to appreciate better the transformations taking place within Scandinavia and their repercussions on communities with which the Norse interacted. Expansion, then, is a term that needs clarification. More specifically, what constitutes expansion for a culture? In this work, expansion means any sustained Scandinavian contact, whether political, martial, economic, or cultural, that results from an influential or physical presence and leaves a lasting effect on the culture contacted. By maintaining this perspective, that a culture's history is intimately bound with its political, martial, and economic history, this work will attempt to provide a more thorough explanation regarding the many factors which influenced Viking expansion c. AD 700-1100. In doing so, this investigation incorporates literary, archaeological, and paleoclimatological evidence to generate new theories regarding northern European history. In addition, older theories are appraised and revised so that they might encompass the entire Scandinavian world. Before proceeding further, however, a sample of the treatment of Viking expansion in other works reveals that a comprehensive examination that expands the previously mentioned brief explanations is essential. 
As the following examples reveal, the reason mentioned most frequently as the impetus behind Norse enterprise was a population explosion that occurred in the mid to late eighth century. According to Ole Jorgen Benedictow,

"...Toponymic and archaeological studies have shown that the populations of the Nordic countries must have grown quite briskly in the Viking period, and that growth on a related scale continued throughout most of the High Middle Ages until it subsided...in the closing decades of the $13^{\text {th }}$ century."1

Knut Helle also agrees with these findings. ${ }^{2}$ In addition to this, Bjorn Ambrosiani feels that although surplus population was involved in conquest, it couldn't have been the sole cause for such an encompassing and enduring phenomenon. ${ }^{3}$ Unfortunately, his speculation ends there.

Calling the Viking expansion a "fierce convulsion," that went through all of the northern lands, F. Donald Logan recognizes that, "the word 'cause' must be stricken from the historian's vocabulary and replaced by the more convenient 'factor,"' due to the myriad of influences that were at work. ${ }^{4}$ However, in describing these factors Logan emphasizes the part played by a population increase and the resulting land shortage. To him, an agrarian, male-dominated society in which polygamy was accepted as the norm for the aristocratic class facilitated a dramatic increase in population. Logan also cites an optimal climate, which opened up new lands for settlement and grazing, as well as new farming techniques, which would have enabled more food to be produced in order to

\footnotetext{
${ }^{1}$ Ole Jorgen Benedictow, "The Demography of the Viking Age and the High Middle Ages in the Nordic Countries," Scandinavian Journal of History 21, no. 3 (1996): 180-181.

${ }^{2}$ Knut Helle, "History of the Early Viking Age in Norway," Ireland and Scandinavia in the Early Viking Age (Blackrock: Four Courts Press, 1998), 246-247.

${ }^{3}$ Bjorn Ambrosiani, "Ireland and Scandinavia in the Early Viking Age: an Archaeological Response," Ireland and Scandinavia in the Early Viking Age (Blackrock: Four Courts Press, 1998), 406.

${ }^{4}$ F. Donald Logan, The Vikings in History (New York: Routledge, 1992), 24-26.
} 
keep this growing population healthy, as minor contributing characteristics to this population increase.

The effect of climate on Viking society has been healthily debated over the years. H. H. Lamb was the first to propose the existence of a Medieval Warm Period (MWP). ${ }^{5}$ Measurements taken from the Greenland Ice Core Project (GRIP) have determined that temperatures during the MWP, which lasted from the eighth through the thirteenth centuries, were significantly warmer than in previous years. ${ }^{6}$ It is during this time that Scandinavian society flourished. By melting glacial ice, this warming trend opened up new avenues for travel on land and sea and freed more land for agricultural use. These findings have generally been accepted and the debate has moved on to whether paleoclimatological evidence gathered from glacial boreholes, tree ring analyses, and the fluctuation in elevation of mountain snowlines supports either a regional or global phenomenon. ${ }^{7}$ At least northern, medieval Europe had warmed up during this period. ${ }^{8}$ Despite the fact that the ability to exploit undeveloped land at home and the potential increase in agricultural resources would support internal expansion and impede external expansion until these means were exhausted, Logan feels that existing trade routes provided knowledge of foreign places and acted as a safety valve for excess

\footnotetext{
${ }^{5}$ H. H. Lamb, "The Early Medieval Warm Epoch and its Sequel," Paleogeography. Paleoclimatology. Paleoecology. 1, no. 13 (1965): 13-37.

${ }^{6}$ D. Dahl-Jensen, et al., "Past Temperatures Directly from the Greenland Ice Sheet," Science 282, no. 5387 (1998): 268-71.

${ }^{7}$ For more information see Ray Bradley, "1000 years of Climate Change," Science 288, no. 5470 (2000): 1353-5 and Wallace S. Broecker, "Was the Medieval Warm Period Global," Science 291, no. 5508 (2001): 1497-9.

${ }^{8}$ Fluctuations in climate would eventually have a hand in halting and nearly erasing Viking expansion across the North Atlantic. As temperatures cooled in successive years, glacial ice reformed and wiped out the Scandinavian settlers in Greenland and the North American continent. For more information regarding this reversal of climactic fortune see, Jean M. Grove, The Little Ice Age (New York: Methuen, 1988)
} 
population. ${ }^{9}$ In light of this, he maintains that trade should not be exaggerated as a motivating factor for migration because of the paucity of evidence regarding the participation of other Scandinavian cultures besides the Swedes. This notion is flawed and will be disproved shortly herein. Although Logan realizes that there are many factors involved in expansion, he implies that all of them have something in common. Each one is merely an extension of population increase as the incentive for outward expansion.

Researchers use this tactic quite often. They use population pressure as the major subject heading under which their other now supplemental material is related within the confines of an increasing populace. For instance, Haraldur Olafsson cites Norway's rugged terrain of steep coasts and mountains as being unable to absorb the growing populace. ${ }^{10}$ However, many of the subsidiary factors mentioned by Viking historians could easily have existed without population pressure as the force behind them. If a blossoming population were removed from the equation, climate, trade, and lack of land would still provide suitable explanations to the expansion phenomenon.

In Viking Expansion Westward, Magnus Magnusson cites wealth as a motivating force before returning to a Malthusian model. He states, "The Danes had been hungrily eyeing the wealth behind its (the Frankish Empire's) defended borders. ... When the Frankish Empire started breaking up ... the Danes struck." ${ }^{11}$ As is the case in many accounts, Magnusson implies that the wealth sought by Scandinavians was most commonly that which was gained from raid. It also supports an 'us versus them' attitude

\footnotetext{
${ }^{9}$ Logan, The Vikings in History, 26.

${ }^{10}$ Haraldur Olafsson, "Sagas of Western Expansion," in Vikings: The North Atlantic Saga (Washington: Smithsonian Institution Press, 2000), 143.

${ }^{11}$ Magnus Magnusson, Viking Expansion Westward (New York: H. Z. Walck, 1973), 21.
} 
in raiding that assumes a unity from the Vikings that just did not exist due to the plethora of independent participants in raiding activities.

Magnusson does make a very important distinction about these raids, though. He notes that the Vikings had realized the opportunity existing in the disputes of others, specifically those in England and Carolingia. ${ }^{12}$ This briefly mentioned notion is of great importance in the work that follows. While the Vikings were by no means innocent of conducting state sponsored raids that financed Scandinavian power politics at home and abroad, it can and will be shown that they were just as eager to attack each other as well as to hire themselves out as mercenaries to fight in their neighbors' causes. The distinction between the types of raid conducted is important because it allows us to distinguish the separate motives behind each of them. One is an act of conquest. Another masks internal political ambitions designed to consolidate power and create unity. The last is more along the lines of "summer employment" rather than simple thievery. All three of these led to the settlement of Vikings abroad. It is once again insufficient to simply cite, as Magnusson does, the desire to acquire wealth by means of raid as a motivation for expansion because not only does it fail to take into account the intention behind the raids, but it also marks all Viking activity as simple thievery. By doing this it ignores that many raids were conducted for other reasons such as conquest and colonization.

When Magnusson returns to the Malthusian model, as most Viking historians do, he too imposes its dominance over another important element in Viking expansion. Using the Icelandic sagas as his source, he states that political pressure from Harald FineHair's ruthless subjugation of Norway (c. AD 880) intensified the expansion caused by a

\footnotetext{
${ }^{12}$ Magnusson, Viking Expansion Westward, 29.
} 
population explosion and resultant land shortage. ${ }^{13}$ This unification process needs to be studied independently because even if the population were remaining constant many would still have been forced to flee from Harald's 'join or die' tactics. In addition, although Magnusson relates this in a strictly Norwegian sense, similar instances were occurring throughout Scandinavia. Denmark and Sweden were also suffering from internal strife which affected the greater scheme of expansion.

Lastly in this review of traditional theories of Viking expansion, David M. Wilson states that a desire for land, which grew from an increase in the number of younger sons with no chance of obtaining the family's holdings, forced people to venture abroad. ${ }^{14}$ Primogeniture and the resulting hunger for land thereby supports the theory that a population increase was the force enabling expansion. More importantly though, Wilson contradicts Logan by stating that a craving for wealth acquired through trade accompanied this need for land. He asserts that, "A cause and consequence of the newly found riches of the Scandinavian people was the settlement of new territory on the basis of a new economy...designed to produce goods for trade." 15 The duality of these events is very significant. While it would be foolish to say that one did not affect the other, it is a tenet of this work that scholars have often undervalued trade-accumulated wealth as a motive for expansion. In addition, an increase in long distance trade was more likely caused by a void in the blossoming trade market than it was by an increasing population. Let us not forget, however, that the concept of land hunger in and of itself is an

\footnotetext{
${ }^{13}$ Magnusson, Viking Expansion Westward 86.

${ }_{15}^{14}$ David M. Wilson, The Vikings and Their Origins (New York: Thames and Hudson, Inc., 1989), 115.

${ }^{15}$ Wilson, The Vikings and Their Origins, 62-63.
} 
abstraction in need of proper explanation. The reasons why men might desire land of their own are as diverse and varied as the men themselves are. ${ }^{16}$

There are those who put little stock in the population explosion theory, however. Myhre feels that it is not possible to show undue pressure on Scandinavian society during either the eighth or ninth century because of the lack of identifiable archaeological evidence. ${ }^{17}$ He does, however, concede that the warmer climate would produce more crops and therefore generate a healthier populace. Peter Sawyer agrees. He states that,

"In Denmark and Sweden there is no hint of population pressure; in those parts of Scandinavia there was abundant unexploited land available for later internal colonization. In western Norway, however, there were few reserves of land..."18

He supports this by citing the presence of Norwegians in the south and west long before other Scandinavians.

In reality, a combination of these viewpoints is probably correct when determining the importance of population to expansion. Geographical restraints provide a stronger physical barrier to internal expansion in Norway than in Denmark and Sweden, but secondary, less tangible factors related to population growth which were occurring throughout all of Scandinavia cannot be ignored in these regions. Polygamy, although dependent on the number of available females for impregnation, combined with the needs of an agrarian society could produce an increase in the number of inhabitants in Scandinavian lands. A warmer climate could allow more land to be available for crops,

\footnotetext{
${ }^{16}$ It is apparent from the sagas that a large number of "common" men in Scandinavia owned their own land, unlike their Carolingian counterparts who held them as tenants of another. This ownership is reflected in the use of the term udal rights. Udal rights have the equivalency of ancestral lands in that they were passed down from generation to generation within a family, but that they were held privately and not owned by a royal or ecclesiastical source from which the lands could be effectively leased.

${ }^{17}$ Myhre, "The Archaeology of the Early Viking Age in Norway," 16-18.

${ }^{18}$ Peter Sawyer, "Scandinavia in the Viking Age," in Vikings: The North Atlantic Saga (Washington: Smithsonian Institution Press, 2000), 29.
} 
more crop rotations to be made, a greater variety of food to be grown, and a healthier diet to be maintained. Better tools and techniques for agricultural practices could produce more food and require less work. As a result of these factors population should increase. An increasing population would create more sons and the confusion inherent in dividing one's legacy, which will be more thoroughly discussed later, would force them to seek lands elsewhere. It is therefore likely that while population did have some effect in Denmark and Sweden, that effect is marked to a much greater degree in Norway.

A second factor of expansion that is frequently cited is the longship. It is easy to see by the sheer volume of references to it in academic and popular literature that one of the most memorable Viking achievements was the development of the longship. The strength and flexibility of its long keel and buoyancy of its broad sides gave the longship the unique ability to withstand the rough waters of the open sea while still being able to cut a shallow enough draught so that it could be maneuvered into shallow river systems. No work on Vikings would be complete without mentioning these technological marvels and how they enabled the Vikings to accomplish so much. Researchers such as A.W. Brogger and Haakon Shetelig have shown that Scandinavians were using boats to harvest the sea for hundreds of years before the Viking Age began and that they were an integral part of Scandinavian culture. ${ }^{19}$ Arne Emil Christensen notes, however, that it is not until the development of the sail sometime in the late seventh century that these ships were used in the capacity that we are familiar with today, namely, for long distance trading and raiding. $^{20}$

\footnotetext{
${ }^{19}$ Anton W. Brogger and Haakon Shetelig, The Viking Ships: Their Ancestry and Evolution (Oslo: Dreyers, 1951).

${ }^{20}$ Arne Emil Christensen, "Ships and Navigation," in Vikings: The North Atlantic Saga (Washington: Smithsonian Institution Press, 2000), 87.
} 
Although the development of the sail and keel did permit these actions to take place, their creation was but a response for the need to travel greater distances with a larger load of either armed men or valuable wares. The Viking ship, then, was a means which enabled expansion to take place and was of itself not a motivation behind expansion. As Lynn White, Jr. states,

"A new device merely opens a door; it does not compel one to enter. The acceptance or rejection of an invention, or the extent to which its implications are realized if it is accepted, depends quite as much upon the condition of a society, and upon the imagination of its leaders, as upon the nature of the technological item itself." 21

Bjorn Myhre's assertion that the development of the Viking ship was a cause for expansion is therefore not tenable in this perspective. ${ }^{22}$ Since Scandinavians employed sails from the late seventh century on, other factors must have arisen by the late ninth century which are more directly related to the reasons why there was a sudden expansion of the Norse world. By no means am I implying that longships were of little importance to this process; that would be like suggesting that wheels are superfluous to riding a bike. Indeed, they are indispensable to it. However, the reason why a child goes to the store is not because the bike has wheels. Since the longship was an instrument of expansion and not a direct motive for it, it has no further place within this discussion.

While there is no doubt that population pressure and the development of the longship are important to Scandinavian expansion, this thesis will maintain that they are principally the result of a prosperous society and, while influential, they are listed too frequently as the major motives for expansion. Researchers do mention other factors, but

\footnotetext{
${ }^{21}$ Lynn White, Jr., Medieval Technology and Social Change (New York: Oxford University Press, 1976), 28.

${ }_{22}$ Bjorn Myhre, "The Archaeology of the Early Viking Age in Norway," in Ireland and Scandinavia in the Early Viking Age (Dublin, Ireland: Four Courts Press, 1998), 18.
} 
neither with the abundance nor the vitality of the former two. For one, population pressure is at best very difficult to prove and many do not agree that it was influential at all. In addition, many of the factors listed as subsidiaries of a population explosion could have affected expansion even in the absence of a population increase. Most importantly, however, neither of these explanations provides a deeper understanding of the reasons why Scandinavians poured into the rest of the world. Although broad social pressures and technological advancements may have affected the Norse during the Viking Age, we must look closely at individuals in order to determine why they chose to leave their homelands in certain ways.

In order to understand fully not only Viking society, but its repercussions on medieval Europe, we must more vigorously investigate what caused the Vikings to spread out so eagerly and rapidly into their surrounding territories. Understanding the factors involved in Viking expansion is critical to understanding the changes that were occurring in the medieval world. Therefore, by bringing the phenomenon of expansion to the forefront of scholarly works instead of relegating it to a footnote, we can better comprehend the transformation of the medieval world. Indeed, there was much more to Viking expansion than just a growing population armed with a technological advancement. Political motives such as the tactics used during the consolidation of power, social motives like outlawry, and economic motives such as raid wealth, trade wealth, and mercenary work, not only lured Scandinavians abroad, but also opened up new opportunities for them in foreign countries. Supplementing this was a society struggling to cope with the change from the turmoil of an aristocratic war band structure, which resembled the Gaulic configuration that Tacitus had earlier labeled a comitatus, to 
a more unified power configuration resembling the feudalism which was emerging in much of medieval Europe.

Whether this oversight is due to the opinion that a trustworthy written record from the Norse perspective does not exist or to an unwillingness to include Scandinavians in the overall economic, political, and social assembly that was medieval Europe is irrelevant to the discussion at this time. Recently, some scholars are attempting a Scandinavian revision that more thoroughly incorporates northern activity into the affairs of the rest of Western Europe. In recent years, Richard Hodges ${ }^{23}$ and Helen Clarke ${ }^{24}$ have been particularly active in redefining what the Vikings and the rest of northern Europe were capable of on the social and economic frontier. Timothy Reuter has shown that Viking military and political organization was not that different from their Carolingian counterpart. ${ }^{25}$ The current work grows out of this revisionist trend and attempts to encourage further study regarding the inclusion of Scandinavia in western medieval history.

It is pertinent at this time, however, to defend briefly the Icelandic sagas as a viable source for historical dialogue. It is the view of Robert Kellogg that the writers of the sagas took 'painstaking' effort to ensure that the transmission of knowledge was accurate. ${ }^{26}$ One way that the saga writers tried to authenticate their stories was by pointing to the continued existence of physical objects, such as in the Saga of the People of Eyri when they mention the Thor stone in the judgment circle. Another instance is in

\footnotetext{
${ }^{23}$ Richard Hodges, Dark Age Economics: The Origins of Towns and Trade AD 600-1000 (New York: St. Martin's Press, 1982).

${ }^{24}$ Helen Clarke, Towns in the Viking Age (New York: St. Martin's Press, 1991).

${ }^{25}$ Timothy Reuter, "Plunder and Tribute in the Carolingian Empire," Transactions of the Royal Historical Society, $5^{\text {th }}$ series, 35 (1985): 75-94.

${ }^{26}$ Robert Kellogg, The Sagas of Icelanders, ed. Ornolfur Thorsson (New York: Viking Penguin, 2000), xxvii.
} 
Grettir's Saga when they link an event which occurred in the past to a place in their present by the discovery of Grettir's lost spear. While it is arguable whether these are accurate means to validate a tale, especially one that deals with monsters, the fact that the authors include them at all shows that they were concerned about credibility. Kellogg states that another tactic of substantiation is the writer's description of how customs had changed over time as occurs in the Saga of Gunnlaug Serpent-tongue. In addition to this,

"Many of those great events can be confirmed by archaeology and the testimony of historical writings in other languages. By and large they must have happened more or less as they are said to happen in the fictional worlds of the sagas." 27

Anderson agrees with Kellogg, but for other reasons. It is a commonly held belief that the sagas evolved from an oral tradition of skaldic poems. Anderson asserts that, "The poems of the skalds are looked upon as fossils capable of great resistance to change, owing to the rigid principles of composition to which the skald had to adhere." ${ }^{28}$ Due to this, the sagas would reflect the accuracy of the original poem. Now, that is not to say that the skalds were above moralizing or judging the characters and their actions in the sagas. Nor would that prevent them from criticizing their forebears or exaggerating their lord's involvement in an event in an attempt to gain more favor from him. These stories only have the authority of the individual writer. The presence of these minor alterations does not change the fact, though, that the events which occurred would still be real and would have taken place even if some liberties were taken in the actual description of said events. As Geraldine Barnes states,

"There may be errors of chronology and geography in the Egil's saga accounts of Eirik's appointment as ruler of Northumbria and Egil's shipwreck at the mouth of the Humber, but the overall narrative

\footnotetext{
${ }^{27}$ Kellogg, The Sagas of Icelanders, xxxi.

${ }^{28}$ Per Sveaas Anderson, Expansion of Norway in the early Middle Ages (Oslo: Tanum, 1971), 14.
} 
impression of its English episodes, which are prefaced by an accurate excursus on English history: ..., is one of historical and geographical verisimilitude. ${ }^{29}$

While the sagas may not be completely accurate, they do contain nuggets of useful information. It is important to note that even if portions of the sagas are historically inaccurate, the motives of the characters expressed within them were considered by the authors to be reasonable for the culture and time in which the participants acted. As with all resources, whether literary or archaeological, historians must mine their source material carefully, taking precaution to rinse off and discard any insignificant or useless debris in an attempt to place them within their proper context. Since this paper seeks to explain the motivating factors that thrust the Vikings abroad, it must therefore explore the potential informational wealth of the sagas.

However, the difficulties inherent in a study of this kind do not stop at just the source materials. After delicately mining the potential resources, further obstacles complicate the presentation of results. Underlying motives for individual instances of Viking activity are difficult to ascertain because of the way that they are interrelated to one another. Many times, multiple motives are the ultimate cause of a single event. In other words, events and the cause of those events do not occur as a singularity in time. They are not synchronic. However, while nothing prevents one motive from overlapping another or occurring simultaneously with a second, it is nonetheless useful for the purpose of explanation to break them down this way in order to understand the multiplicity of Viking rationale. A synchronic viewpoint allows us to study each motive

\footnotetext{
${ }^{29}$ Geraldine Barnes, "The Medieval Anglophile - England and its Rulers in Old-Norse History," Parergon 10, no. 2 (Dec 1992): 21.
} 
separately without additional baggage attached to it. Hopefully in this way, a clearer, well-rounded, and more accurate depiction of Viking expansion can be revealed.

Nevertheless, time and the study of history prevent us from completely separating these motives from the surrounding contexts. In order to appreciate fully the process of Viking expansion, the separate pieces must be reincorporated with one another so that history is reconstructed. As a mechanic might tear a bike apart to learn how each part works, the bike must be put back together in order for it to function. Although examining the parts individually provides an understanding of how a process operates, there is a chronology that is necessary to actually comprehend that process. For instance, although trading relationships may have originally established contact with foreign lands, trade does not disappear as a factor in expansion once raiding begins. Not only did it come first, but it was also perpetual throughout the Viking Age. The inevitable assumption that once something occurred it was unlikely to occur again or that its effect would no longer be felt must be resisted at all times. The trick is to remember that these steps, although they are being observed in a vacuum, did not occur in one. Therefore, after identifying the catalysts of Viking expansion singularly, this work will then incorporate them together in order to explain specific events that occurred during the Viking Age.

It is therefore useful at this time to conceptualize the range of Viking activities and potential motives for expansion during the time in question, that is, from approximately AD 700 through 1100. Scandinavian lifestyles were not very different from English or Frankish ones. Gwyn Jones stated that there were only five modes of making a living in the northern world. They were, “...by agriculture, fishing and 
hunting, following a craft, buying and selling, or robbing and fighting."30 Slavery was widespread and many slaves worked the land for their peasant or noble masters. Freemen either ran the farms of larger landowners or owned smaller farms themselves. These people lived off of the land, hunting and farming to feed and clothe themselves or, if the opportunity arose, to sell their surplus to others. Most farms, whether large or small, housed a blacksmith's shop in order to make or repair the necessary items for farm maintenance. In this way, some learned to fashion the raw materials that they gathered into more valuable items and supported themselves by a craft. ${ }^{31}$ A select group of individuals, the aristocratic class, owned even more land as well as a number of slaves. The larger farms would have more people at them with more skills and would therefore be able to produce more goods for trade than smaller ones. These aristocrats attracted ambitious young men to their households for defense of the surrounding lands from neighboring territories or bandits and potentially to raid neighboring lands.

Scandinavians, as with the people of all cultures, displayed a variety of seemingly contradictory pursuits. What this means is that they were just as capable of shedding blood as they were of shaking hands. Although they commonly conducted raids for plunder, they were also willing to participate in the peaceful manufacture of goods for sale in an expanding trade market. Their range of activity stretched from one end of the spectrum, such as bloodthirsty conquest, to the other, like peaceful migration. It is

\footnotetext{
${ }^{30}$ Gwyn Jones, History of the Vikings (New York: Oxford University Press, 1984), 182.

${ }^{31}$ Egil's Saga reveals much of this organizational structure in chapters 28 through 30 . Here, Egil's father, Skallagrim, a wealthy landowner, gave each of the crewmen on his ship a parcel of land for their very own. Skallagrim also had a man named Gris run one of his three farms with livestock and two other men named Odd and Sigmund operate his salmon fishery. In addition to these activities, Skallagrim collected driftwood, a valuable source of wood in Iceland, and kept himself busy during the winter by working large amounts of iron in the farm's smithy. As for armed men, he later easily equips Egil with around 300 men to go to England and find mercenary work with King Aethelstan.
} 
therefore sometimes difficult to understand how one group of people could exhibit such diversity in behavior.

One of the hurdles in overcoming this difficulty is to not think of them as one people even though they are referred to as one. Although Christendom at that time may have viewed them as a single entity, the Vikings were anything but unified.

Scandinavian landscape, political arrangement, and social custom often prevented this concord. Much of the internal conflict that arose within Scandinavia, such as Harald Finehair's consolidation of Norway, grew from attempts to create unity and commonality within particular regions. However, instead of getting embroiled in a discussion concerning how the Vikings identified themselves, it is more productive for the purposes of this study to examine the common personal, political, and social motives behind these activities.

Whether by peaceful trade or violent mercenary work, many Scandinavians realized that an opportunity for personal advancement could be obtained abroad. At this time, few ways existed in which someone could make a living. Although agricultural work and animal husbandry were the most common forms of employment, many Scandinavians recognized that a greater opportunity for acquiring wealth, land, or prestige, i.e. the means to increasing one's standard of living, was availed by undertaking foreign adventure. Trade and raid in this sense were both employment opportunities.

However, personal gain was not the only force behind raiding. The political aspects of raiding were also important to expansion. Specifically, three political motives propagated external raiding by Scandinavians. They were either attempts to forcibly conquer foreign lands, finance revolutions at home, or insert individuals into existing 
power structures as key political figures. Another politically charged motive is the consolidation of power within Scandinavia, which forced many people, nobles and commoners alike, to flee into foreign realms seeking a new start. One of the results of these internal power struggles was the creation of political exiles. These men were banished from their homelands because they were threats to the security of the current ruler. Related to this is the social outlaw, one who was banished by society for breaking established codes of conduct. Other societal norms that affected expansion are polygamy, inheritance rights, and prestige maintenance.

These motivations ran through all of the Scandinavian cultures. Together, personal opportunity, political maneuvering, and societal customs were the three factors most responsible for Scandinavian expansion before, during and after the Viking Age. Although all of these intermingle with one another on almost every level, each one can and will be studied separately in order to fully appreciate why the Vikings flooded into the Christian world to such a great extent. By possessing this knowledge, we can gain a better understanding of the events as they occurred as well as their repercussions throughout the affected societies. 


\section{Chapter One: Employment Opportunity}

In order to identify properly the forces that motivated Viking expansion, it is imperative that we understand who the Vikings were. The current perception of Vikings as farmers and marauders with only occasional mercantile activities is overly simplistic and ultimately fails to incorporate the progression of events which led to the eventual adoption of raiding as a widespread form of income. Indeed, the Vikings specialized in long distance trading long before the inception of the Viking Age and maintained this employment during it. Often, they were more interested in a profit by trade than by raid. In addition to working as nearly worldwide merchants, Vikings would come to find other work as hired men-at-arms, mercenaries of the finest caliber, who could earn lasting fame, an enormous fortune, and potentially even land of their own all by fighting for pay.

\section{Section 1: Trade}

It is through the role of merchant that Scandinavians would first impact Western Europe by reaching out and establishing footholds on foreign shores. Philip Curtin states that societies often harbor anti-mercantile views, much like those that afflicted the Phoenicians and the Jews, and that this encouraged people to leave trade in the hands of 
foreigners. ${ }^{32}$ Curtin provides a general description of those participating in this mercantile role:

"Commercial specialists would remove themselves physically from their home community and go live as aliens in another town. ... They could then serve as cross-cultural brokers, helping and encouraging trade between the host society and people of their own origin who moved along the trade routes." 33

Having the maritime technology and the need to seek supplies elsewhere due to their northern locale, the Vikings were a natural fit for this kind of specialization. Tales of the wealth that passed through their hands and the desire to obtain a share of it whether for greed or subsistence would entice others to participate in this lifestyle. Together, these conditions would help propagate the expansion of Scandinavian people throughout Europe and beyond.

Even after Vikings began their continual raiding and colonization of foreign territory, maintaining or even improving the existing economic conditions of newly acquired lands occupied their efforts to a great degree. So widespread was this occupation in fact, that it was at least as equally important as conquest and in many cases wealth obtained through legitimate trade was the predominant means of support. This is not to say that the Vikings were innocent of their infamous, murderous rampages. However, archaeology and literary documents prove that the Vikings had a marked interest in playing the role of a trader, albeit an aggressive one, who was prone to use force to fuel his mercantile ambitions if such opportunity arose. Therefore, it follows that since there was a significant amount of Scandinavian interest in earning a living through trade, trade would be a significant motive for expansion.

\footnotetext{
${ }^{32}$ Curtin, Philip D. Curtin, Cross Cultural Trade in World History (NY: Cambridge University Press, 1984), 6 and 75.

${ }^{33}$ Curtin, Cross Cultural Trade, 2.
} 
At first, the Vikings received a great deal of bad publicity that began with early Christian writers in the late $8^{\text {th }}$ century AD. The negative views of these monastics came as no surprise due to the raids conducted by foreign, heathen men on the wealthy lands of the church which are now thought to have provided a storehouse for local valuables. ${ }^{34}$ However, this biased belief also comes hundreds of years after our subjects had been participating in a prosperous and growing maritime trade. Gradually, our concept of what these marauders were capable of changed to incorporate a variety of positions that held that they were more than just murderous heathens. Henri Pirenne made a large contribution in this regard. A corollary to his famous thesis suggested that Charlemagne's empire turned to the northland's merchant activity for economic revival. ${ }^{35}$

Pirenne was one of the first to imply that there was more to the Northmen than previously believed. He suggested that perhaps the Norse were not just barbarians out to make a quick and bloody buck. Due to researchers who based their work largely upon Pirenne's theories, the Vikings have been found to be intrepid explorers, rugged farmers, and seasonal maritime traders as well as their less savory aggressive counterparts. However, as more and more archaeological remains are uncovered, which constitutes the lion's share of evidence available to Viking historians, even these ideas have come into question. The presence of over one hundred collapsible scales in Sweden alone, which were based on an Islamic system of measurement from c. AD 696, attests that previous

\footnotetext{
${ }^{34}$ Mary A. Valante, "Reassessing the Irish Monastic Town," Irish Historical Studies 31, no. 121 (May 1998): 7.

${ }^{35}$ Henri Pirenne, Mohammed and Charlemagne (New York: Barnes and Noble, Inc., 1955), 195 and 240.
} 
notions fail to reflect the increased levels of trade that Scandinavians actually participated in. $^{36}$

Helen Clarke has argued that since the written evidence for the later Middle Ages shows a livelier trade than even archaeology can ascertain, there existed a, “... much more extensive trade in essential goods in the Viking Age than can be established from the archaeological evidence." 37 In addition, based on the numerous remains of Scandinavian freight vessels designed to haul bulk commodities, she inferred that even though the cargoes aren't preserved archaeologically, the ships themselves are evidence enough for scholars to accept an increased level of Scandinavian participation in the long distance transportation of miscellaneous merchandise. ${ }^{38}$ The knarr, a style of Scandinavian ship with an approximate 30-ton carrying capacity, does in fact translate from Old Norse to mean "merchantman."39

In order to resolve appropriately the dilemma of the level of Viking involvement in the economy of Northern Europe and thereby establish the extent to which trade was a motivating factor of Viking expansion, a few items need to be investigated. First, this paper will seek evidence of an economic community that was capable of supporting such mercantile ventures on a regular basis within the North and Baltic Seas in the era immediately before the Viking Age, c. AD 600-800. If this community existed and was in need of Scandinavian merchandise, be it either luxury goods or everyday commodities, then it would be reasonable to suggest that long distance traders from Scandinavia with

\footnotetext{
${ }^{36}$ Egil Mikkelsen, "Islam and Scandinavia During the Viking Age," Byzantium and Islam in Scandinavia: Acts of a Symposium at Uppsala University, June 15-16, 1996, ed. Elisabeth Piltz, (Jonsered: Paul Astroms Forlag, 1998), 45.

${ }^{37}$ Helen Clarke, "English and Baltic Trade in the Middle Ages," Society and Trade in the Baltic during the Viking Age. ed. Sven-Olaf Lindquist (Visby: Gotlands Fornsal, 1985), 118.

${ }^{38}$ Clarke, "English and Baltic Trade," 118.

${ }^{39}$ Clarke, Towns in the Viking Age, 130.
} 
no murderous intentions could have existed and could also have been an active part of long distance trade. Secondly, in order to get an accurate idea of how the Vikings conducted business and what should be considered a Viking business venture, this paper will search the literary record for evidence that reported the tactics of these men during mercantile activities. Indeed, it can be shown that over time the Vikings were economic opportunists, equally as ready to strike a truce for trading as well as ransack a city or church for spoil depending on the purpose of their journey. However, even after their conquest of new lands, the productive and commercial aspects of these new territories consumed their attentions because conquering an area and forcing it to pay tribute was merely a means of acquiring the raw materials necessary to fuel trade. Lastly, this work will conduct an overview of the activities of the Northmen during the Viking Age, c. AD $800-1100$, to show that economic motivation through trade still existed for them although it was practiced in conjunction with the tactics described above, namely, hand in hand with violence. If these three things are verified, then it is reasonable to suggest that gaining wealth through trade was a significant motivation for Vikings to venture abroad. Seeking or supplying trade goods would therefore be a factor in Viking expansion.

\section{Economic Community Before AD 800}

To accomplish the first part of the task at hand, it may be beneficial to start this journey with a word or two about the culture that existed in northern Europe during the transformation of the Roman Empire in order to set the stage for what was to come. In many of the excavated sites in central Jutland, which constitutes much of present day Denmark, “... uninterrupted continuity of settlement...can be demonstrated for the whole 
of the first millennium AD," unlike that of Gaul. ${ }^{40}$ It seems that the northern population was not as affected as was Gaul by the barbarian invasions. In addition, during this time a great deal of exchange took place back and forth along the northern frontier of the Empire with these regions. Be it trade, tribute, plunder, or gift exchange, Roman merchandise, predominately luxury items such as glass vessels, indicate viable merchant activity with Scandinavia before the fall of the Roman Empire. ${ }^{41}$ However, as Rome's part in this trade began to decline, due to the internal and external threats that eventually brought about its demise, Scandinavian economy, as well as that of most of Europe, shifted to more locally manufactured goods. As the influence of Rome declined in the area, local Scandinavian leaders were able to establish their control over the seasonal markets that had blossomed under Roman contact. ${ }^{42}$ It is in these areas, such as Lundenborg on Funen in Denmark, which would later develop into permanent emporia and had Baltic-wide trade connections. As evidence of this area's prosperity in the fifth century, Richard Hodges cites the discovery of primitive conditions by the Jutes' standards upon their migration from western Denmark to sub-Roman Britain, a locale known to have continual trade and access to luxury goods from continental Europe. ${ }^{43}$ While the prosperity of Lundenborg may be anomalous for all sites in Scandinavia at this time, such trading stations were to spring up throughout the Baltic in the forthcoming years.

\footnotetext{
${ }^{40}$ Klaus Randsborg, "Barbarians, Classical Antiquity, and the Rise of Western Europe: an Archaeological Essay," Past and Present, no. 137 (Nov. 1992): 22.

${ }^{41}$ Arhus Ulf Nasman, "Vendel Period Glass from Eketorp II, Oland, Sweden," Acta Archaeologica 55 (1984): 56.

${ }^{42}$ Klaus Randsborg, "The Demise of Antiquity: Europe and the Mediterranean in the First Millennium AD," Annual Review of Anthropology 18, (1989): 236.

${ }^{43}$ Richard Hodges, “The Not-So-Dark Ages,” Archaeology 51, no. 5 (Sept-Oct 1998): 62.
} 
What arose from these conditions was a social and economic climate much different from that of the rest of Europe. Since Roman contact had not existed long enough for their influence to saturate the Scandinavian countries, the establishment of a market economy and its benefits had not yet been fully realized. Therefore, when Rome withdrew upon itself, Scandinavian economies had never reached the peak from which the rest of Europe would fall into the dark ages. In essence, the Roman influence only had enough time to show the Northmen how to do things better, but had not yet permeated their lives so much as to drastically improve the quality of living for most individuals or to threaten the quality of life after they departed. The evidence that many sites in the Danish area can show continuity of settlement from late antiquity through the Viking Age coupled with the fact that these villages would gradually grow to larger, more wealthy emporia indicates that Scandinavian territories did not experience a fall into the "dark age" due to the fact that they had nowhere to fall from. Their progress moved slowly forward into a time when economic expansion was developing throughout the rest of Europe.

This time of expansion, c. AD 600-800, is especially important to Scandinavian communities. Unfortunately for historians, there is little literary evidence in this time from which they can draw conclusions. Archaeology provides the lion's share of evidence regarding Scandinavians during this era. Previously, scholars believed that during this period, conditions were dismal for most of Europe. Some have suggested, such as Richard Hall, that during this era the Vikings are to be identified as merely, "... farmers and fishermen turned pirates." ${ }^{, 44}$ As previously mentioned, this theory has begun to crumble away. It now appears that while life may not have been as vibrant as in

\footnotetext{
${ }^{44}$ Richard Hall, "The Vikings as Town-Dwellers," History Today 36 (Nov. 1986): 29.
} 
Roman times, it certainly was not as decrepit as was once imagined. Some have even gone so far as to suggest that the volume of long distance trade in Northern Europe eclipsed the amount of trade conducted over the ancient silk roads from AD 600-1000. ${ }^{45}$ An overview of each of the areas involved may help to substantiate the proposed increased levels of economic activity in northern Europe as well as prove that economic conditions existed that would support regular, peaceful, long distance commerce conducted by Scandinavians.

Before starting this geographical survey of Baltic trade during AD 600-800, a few items need to be clarified. Rather than getting embroiled in the debate as to whether or not actual urban centers defined as "towns" existed prior to or during the Viking Age, I have decided to forgo any lengthy discussion of what constitutes urbanity. This is due to the nature of the question under examination. While the existence of towns with a market economy may bolster the idea of envisioning the Vikings as commercial specialists, due largely to a town's capacity to allow the volume of trade to be greater, the lack of an established town does not necessarily preclude Viking activity as regular long distance traders. What is important is that if a site shows evidence of the manufacture of surplus materials for trade or widespread recovery of foreign artifacts, that they be included to show the quantity and frequency of the transmission of said goods over a broad area. Just because the permanent population of a town did not reach some predetermined number is no reason to exclude the notion that merchants visited these sites regularly as a primary means of support after gathering their goods. Attached to this concept is the notion that only those whose primary employment was that of trader be included in the calculation.

${ }^{45}$ Jerry H. Bentley, Old World Encounters (NY: Oxford University Press, 1993), 69. 
Trade in Scandinavia should not be restricted to full time merchants. Lesser agents, such as small farms and farmers with either surplus or crafted wares, were also involved.

In addition, just because a market is seasonal does not mean that the data gained from that site is not useful. It takes time to manufacture many of the objects of wealth that would be traded, such as bone combs or skates, necklaces of amber, glass, or metal, and iron materials such as weapons and tools especially if the craftsman is making a quantity of them for sale. These items require some skill in craftsmanship. Also, contemporary accounts of trading voyages such as Othere's journey to Hedeby, ${ }^{46}$ which can be calculated to five weeks one way with good winds, took a great deal of time. Therefore, visiting a trading site once a year (or twice if you count the return trip) is about as regular as you can be when you take into account the time necessary to acquire the materials, work them into something more valuable, and then transport them as well.

Lastly, it is a modern notion that trade must be continual in order for it to be significant. As scholars, we need to readjust our thinking to include the limitations of the world in which the Norse lived. If a farm had run out of supplies in the middle of winter, such as food, leather, furs, or the like, it would serve no purpose to go buy them somewhere because they could not easily be replenished by others and the trip would be overly dangerous. In addition, if a farm needed 50 pounds of goods to supply themselves amply for an entire year, the volume of goods required to run the farm would remain the same regardless of the number of trips to the market. In fact, by buying in bulk and on one trip, the farm has probably saved money on the deal and has definitely saved manhours better spent tending fields. Their thriftiness and time management skills should not exempt them from being included in an economic study.

${ }^{46}$ The Old English Orosius, ed. Janet Bately (London: Oxford University Press, 1980), Book I, Chapter I. 
Although Sweden, and more importantly its leading market town Helgo, was the farthest removed from Roman contact, it exhibited a great deal of mercantile activity both regionally and internationally, so it is therefore a good place to start. Upon reviewing the archaeological information for Sweden, as well as for many of the other Scandinavian regions, the picture that begins to emerge is one of continual growth. Helgo, the primary market center for Sweden which would later be replaced by Birka in matter of importance, was in use from the $5^{\text {th }}$ or $6^{\text {th }}$ centuries onwards. ${ }^{47}$ According to Nasman, the appearance of specialty purpose sites such as this which were geared towards the overproduction of crafts for trade is a radical change from the past and their rapid emergence is easily reflected in the wide social distribution of reticella glass. ${ }^{48}$ Indeed, the over 90,000 mold fragments and approximately $300 \mathrm{~kg}$ of crucibles found are a testament to Helgo's industrial character. Quantities of this degree suggest surplus production intended for trade. Not only that, but Ambrosiani has proposed that the distribution of wealth in families of the Malaren area in Sweden suggests the organized production and trade of iron from c. AD 600 onwards. ${ }^{49}$ Archaeological evidence, such as workshop remains and social stratification of graves supports his theory that the immediate and regional hinterland sent their raw materials to be worked into valuable goods in the industrial quarters of Helgo. The materials from the surrounding areas were rounded up and brought to the royal city where the king could control the tax on and distribution of trade goods.

\footnotetext{
${ }^{47}$ Clarke, Towns in the Viking Age, 70

${ }^{48}$ Nasman, "Vendel Period Glass," 96-97.

${ }^{49}$ Bjorn Ambrosiani, "Specialization and Urbanization in the Malaren Valley - a question of maturity," Society and Trade in the Baltic during the Viking Age, ed. Sven-Olaf Lindquist (Visby: Gotlands Fornsal, 1985), 109.
} 
Major Ports of the Baltic Sea

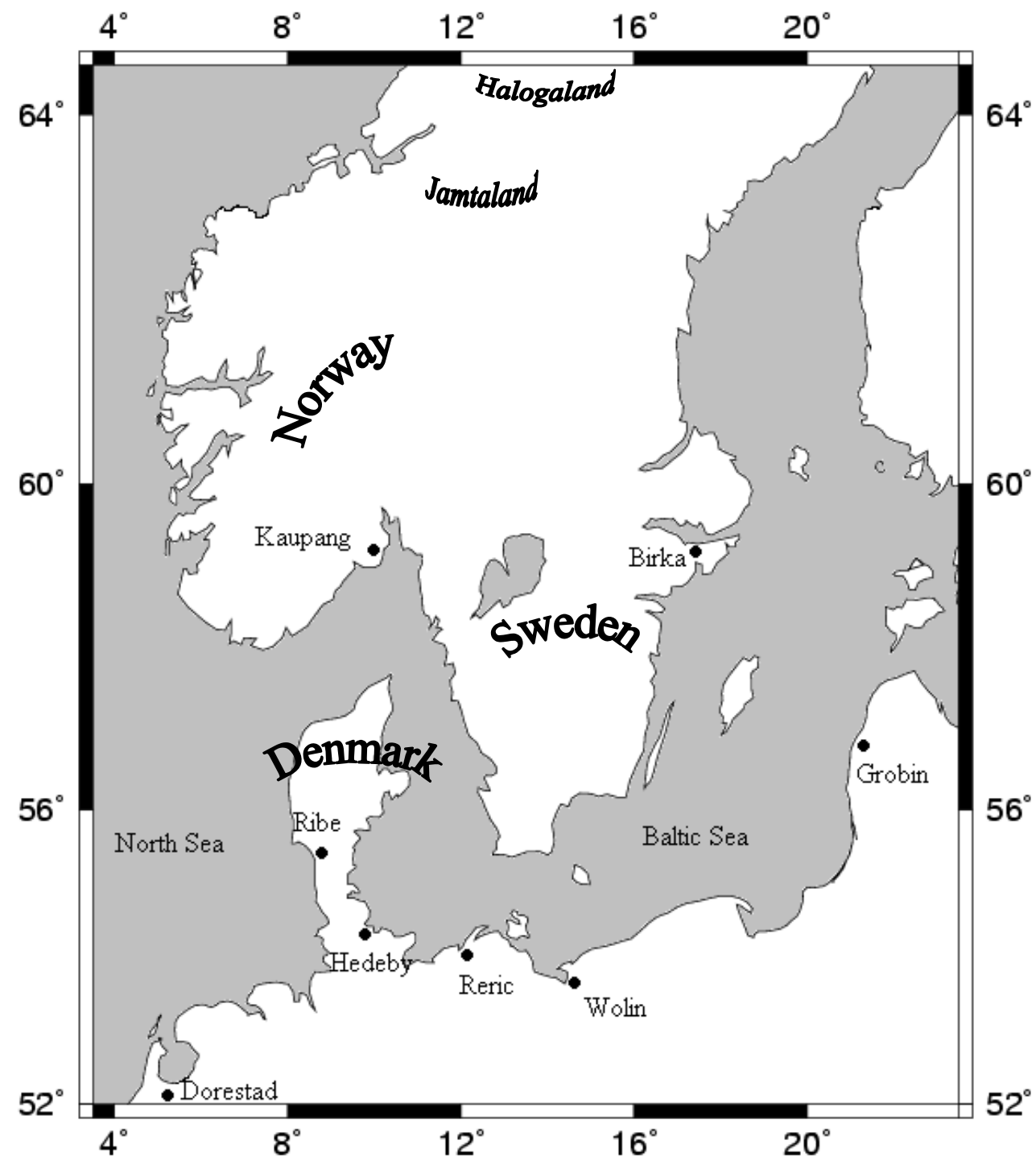

\section{Legend}

$\begin{array}{cc}\bullet & \text { Town } \\ \text { Denmark } & \text { Territory } \\ \text { Jamtaland } & \text { Region }\end{array}$

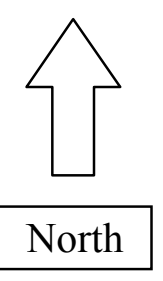


Thus far, none of the evidence cited involves more than regional trade. All of this surplus could have been geared towards providing for regions along the Baltic. While sailing across the turbulent waters of the Baltic Sea would by no means be an easy feat in an early stage clinker built ship, a later voyage of Anskar c. AD 852 would require 20 days to sail from Hedeby in Denmark to Birka in Sweden (which was just outside of the location of Helgo $),{ }^{50}$ it would be more telling about the level of Swedish trade if evidence existed on a more international scale. Nasman provides this evidence. He furnishes a clear argument that from the very start of his period VII (c. AD 550-750/800), an English manufacture of most of the Scandinavian beakers seems most probable and narrows their point of origin to Kent. ${ }^{51}$ Nasman continues by showing that direct contact with the Merovingian kingdom is evident through the import of sword pommels dating from the $6^{\text {th }}$ century. ${ }^{52}$

Norway, unlike Sweden, does not have as clear an archaeological timeline as its neighbor due to its relative scarcity of excavated sites. New excavations at its major trading center Kaupang, however, indicate that this emporium did in fact house year round occupation which began c. AD $700 .^{53}$ Kaupang has successfully been identified as Sciringesheal, the destination which Othere described to King Alfred in the Orosius. ${ }^{54}$ The implications of Othere's travels and trading tactics will be discussed later. Trader's scales and craftsman facilities identified in Kaupang indicate the processing of soapstone,

\footnotetext{
${ }^{50}$ Saint Rimbert, Anskar: the Apostle of the North, 801-865, trans. Charles H. Robinson, D.D. (The Society for the Propagation of the Gospel in Foreign Parts, 1921).

${ }^{51}$ Nasman, "Vendel Period Glass," 75.

${ }^{52}$ Nasman, "Vendel Period Glass," 88.

${ }^{53}$ Dagfinn Skre, "New excavations of Kaupang, a Viking Age Port of Trade." n.d.

$<$ http://www.kaupang.uio.no/Engelsk_hovedside.htm> (April 3, 2000)

${ }^{54}$ The Old English Orosius. Book I, Chapter I.
} 
the working of metal and glass, and the repairing or building of ships. ${ }^{55}$ The presence of a shipyard for construction or repair strongly implies at least regional contacts and possibly international ones as well. Of particular importance to Norway is the establishment of a specialist industry in iron production and mica-schist hones. These hone stones have been found in nearly all rural medieval sites around the Baltic and later came to dominate the northern European market for such materials. ${ }^{56}$

Denmark is last in the Baltic arena to be studied, but it is definitely not the least important. Denmark boasts the greatest number of c. AD 600-800 trading sites with Ahus, Ribe, Hedeby (although late), Loddekipinge, and the aforementioned Lundenborg. Ahus, located on the southern tip of present day Sweden, which during the time in question was under Danish control, traces its origins back to the early $8^{\text {th }}$ century. This permanent market specialized in working bronze and antler in addition to exhibiting ties to Slavonic lands and the Rhineland through pottery shard remains. ${ }^{57}$ Ribe, while it is suspected to only have been a seasonal market at this time, began its existence in the mid $8^{\text {th }}$ century $^{58}$ and continued in its capacity as Denmark's most important trading site on the mainland until the foundation of Hedeby (Haithabu) near the close of the same century, dating to a time before the sacking of Reric, a Saxon town on the Baltic under Carolingian control. ${ }^{59}$ Hedeby boasts not only furs and slaves from the Eastern Baltic, but glassware and weapons from western countries, soapstone from Norway, and a craftsman center that worked pottery, glass, metal, amber, textiles, horn, and bone for

\footnotetext{
${ }^{55}$ Richard Hodges, Dark Age Economics: The Origins of Towns and Trade AD 600-1000 (NY: Saint Martin's Press, 1982), 81.

${ }^{56}$ Hodges, Dark Age Economics, 124-125.

${ }^{57}$ Clarke, Towns in the Viking Age, 55.

${ }^{58}$ Hodges, Dark Age Economics, 80.

59 "Royal Frankish Annals," Carolingian Chronicles, trans. Bernhard Walter Scholz (Ann Arbor: University of Michigan Press, 1970), year 808.
} 
distribution. ${ }^{60}$ Many of these goods, like the soapstone, horn, and bone items, were everyday commodities and indicate that trade involved more than just luxury items. In addition to these sites, Richard Hodges and David Whitehouse have shown that Loddekopinge, also located on the Southern coast of present day Sweden, was an active trading site that displayed abundant signs of Viking mercantile activity possibly as early as $\mathrm{AD} 800 .^{61}$

These sites were not the only ones to appear on the Baltic with trading capabilities. Adam of Bremen, Saxo Grammaticus, and the Icelandic sagas mention Wolin in Eastern Germany, which possessed a craftsman center by c. AD $700{ }^{62}$ Grobin in Poland also existed as an important Scandinavian trading site. ${ }^{63}$ Starigard, now Odenburg, was founded c. AD 700 and had a royal hall and a craftsman center. ${ }^{64}$ Activity in the Baltic on the Russian side of the Baltic Sea is also evident. By c. AD 760, Staraya Ladoga, the halfway point to Novgorod, housed metal smiths as well as bone and antler smiths of Viking origin. ${ }^{65}$

What is especially significant about all of these trading sites together is the rapidness with which they all emerged in and around the Baltic Sea area before AD 800 . As Jens Ulriksen states, “The $\left(8^{\text {th }}\right)$ century's boom in landing places is in part

\footnotetext{
${ }^{60}$ Hilda Roderick Ellis Davidson, The Viking road to Byzantium (London: George Allen and Unwin Ltd., 1976), 69.

${ }^{61}$ Richard Hodges and David Whitehouse, Mohammed, Charlemagne, and the Origins of Europe (Ithaca: Cornell University Press, 1983), 117-118.

${ }^{62}$ Clarke, Towns in the Viking Age, 112-114.

${ }^{63}$ Hodges and Whitehouse, Origins of Europe, 117-118.

${ }^{64}$ Clarke, Towns in the Viking Age. 108.

${ }^{65}$ Clarke, Towns in the Viking Age. 120.
} 
contemporaneous with archaeological evidence for the incipient trade in "everyday goods" such as basalt grinding stones, slates for whetstones, and soapstone vessels." ${ }^{\text {"66 }}$ These locations and their capacities for trade indicate an economy that had, in the beginning, been primarily involved with the sale of luxury items, but was evolving to the point where every day commodities could also be transported over distance for a profit. Klaus Randsborg recognizes this continual development, separated as it was from the transformation of the Roman Empire, and argues that it would integrate easily with the emergent economies of Merovingian and Carolingian times. ${ }^{67}$

In continental Europe, the years surrounding the seventh century show that urban culture had once again begun to flourish. The establishment of Quentovic and Dorestad during the seventh century, among others, indicates that the Merovingian and Carolingian dynasties were ready to take advantage of the increasingly valuable economic situation in the North Sea. Pirenne himself noted that the Carolingian Empire had two economically active trading regions: one in northern Italy, trading for Mediterranean goods such as oils, wine and the like, and the other in Frisia and Scandinavia, trading for furs and iron. ${ }^{68}$ That the Frisians have been noted as the most prominent traders of Northern Europe ${ }^{69}$ indicates that the trading stations along the coast of the North Sea were not only of vital importance to the empire, in that they provided a much needed source of royal wealth from taxation, but that an economic network had also evolved there. The Frisians even

\footnotetext{
${ }^{66}$ Jens Ulriksen, "Danish sites and Settlements with a Maritime Context, AD 200-1200," Antiquity 68, no. 261 (Dec. 1994): 804.

${ }^{67}$ Randsborg, "Rise of Western Europe," 24.

${ }^{68}$ Pirenne, Mohammed and Charlemagne, 240.

${ }^{69}$ Hodges, Dark Age Economics, 87.
} 
had a trading settlement at York, although Jones feels that the amount of trade encompassed here would have been limited and irregular. ${ }^{70}$

It stands to reason then, that since this extensive trading route existed and was energetic, the Scandinavians, especially the Danish with their western port of Ribe, would participate in this trade as well. In chapter XXVII of Saint Rimbert's Anskar: the Apostle of the North it is reported that when Anskar returns for a second time to Sweden c. AD 852, one of the older men of the village supports his attempts at conversion based largely on what some of them, presumably traders, had witnessed about Christianity during their visits to Dorestad. In conducting his investigations on glass importation from England to Scandinavia, which would have passed along the Frisian coast, Nasman supports a, “...greater and more active Norwegian and Swedish participation in the trade." ${ }^{, 71}$ One supposes that the Danish traders who appeared outside of Dorchester in AD 789 as documented by The Anglo-Saxon Chronicle ${ }^{72}$ and The Chronicle of Aethelweard ${ }^{73}$ would have followed this, the easiest and most profitable route.

In actuality, Charlemagne was eager to garner the attentions of Scandinavian merchants. According to the Royal Frankish Annals for the year AD 782, Charlemagne held an assembly at the River Lippe in Saxony to negotiate a treaty with the Danes. This treaty would inevitably help turn the empire's economic attention northwards. The founding of Reric on the Baltic Sea also points to further interest from Charlemagne in maintaining exchange with Scandinavians. To Hodges and Whitehouse, this interest in

\footnotetext{
${ }^{70}$ S.R.H. Jones, "Transaction Costs, Institutional Change, and the Emergence of a Market Economy in later Anglo-Saxon England," Economic History Review 46, no. 4 (1993): 664.

${ }^{71}$ Nasman, "Vendel Period Glass," 89.

${ }^{72}$ The Anglo-Saxon Chronicle, trans. G.N. Garmonsway (New York: Dutton, 1965), year 789, version A and $\mathrm{E}$.

${ }^{73}$ The Chronicle of Aethelweard, trans. A. Campbell (London: Thomas Nelson and Sons, Ltd., 1962), Book 3, Chapter 1.
} 
northern wealth would bring about the Carolingian coin reforms of AD 793-794 which increased the weight of their coins in an attempt to redirect commerce due to the proliferation of Scandinavian silver. ${ }^{74}$

Trade in England, however, followed a different pattern. Ever since Rome had departed England, English leadership had been in disarray and remained so until invasion forced them to unite. One needs not look far to find that royal power quickly changed hands. The Chronicle of Aethelweard and The Anglo-Saxon Chronicle both show at various times rulers deposing one another while participating in inter-regional war throughout all of England. This unstable environment made for a difficult economic atmosphere at best. However, although Jones states that the relatively small amount of coinage in circulation during this time reflected the restricted nature of trade,${ }^{75}$ it could also be this unstable situation that lead to this scarcity of coin. Coins don't make themselves and without a stable ruler to commission their striking and guarantee their metallic content, their number would dwindle in circulation as people hoarded or melted them down for other purposes. New coins would not be made until a ruler established himself and wished to either increase the market value, as Charlemagne did in AD 793, or use it as a means to unite his lands, as Aethelred attempted to do in AD 979 and 985. Evidence that trade flourished in England during this time exists in the foundation of many wics, the name ending used to designate principal trading centers, most of which were located on river inlets. Hamwic (Southampton), Ipswich, and Eoforwic (York) were all the precursors of medieval market towns and had their origins either during or before c. AD $600-800$.

\footnotetext{
${ }^{74}$ Hodges and Whitehouse, Origins of Europe, 109-115.

${ }^{75}$ Jones, "Market Economy," 661.
} 
Major Ports of the North Sea

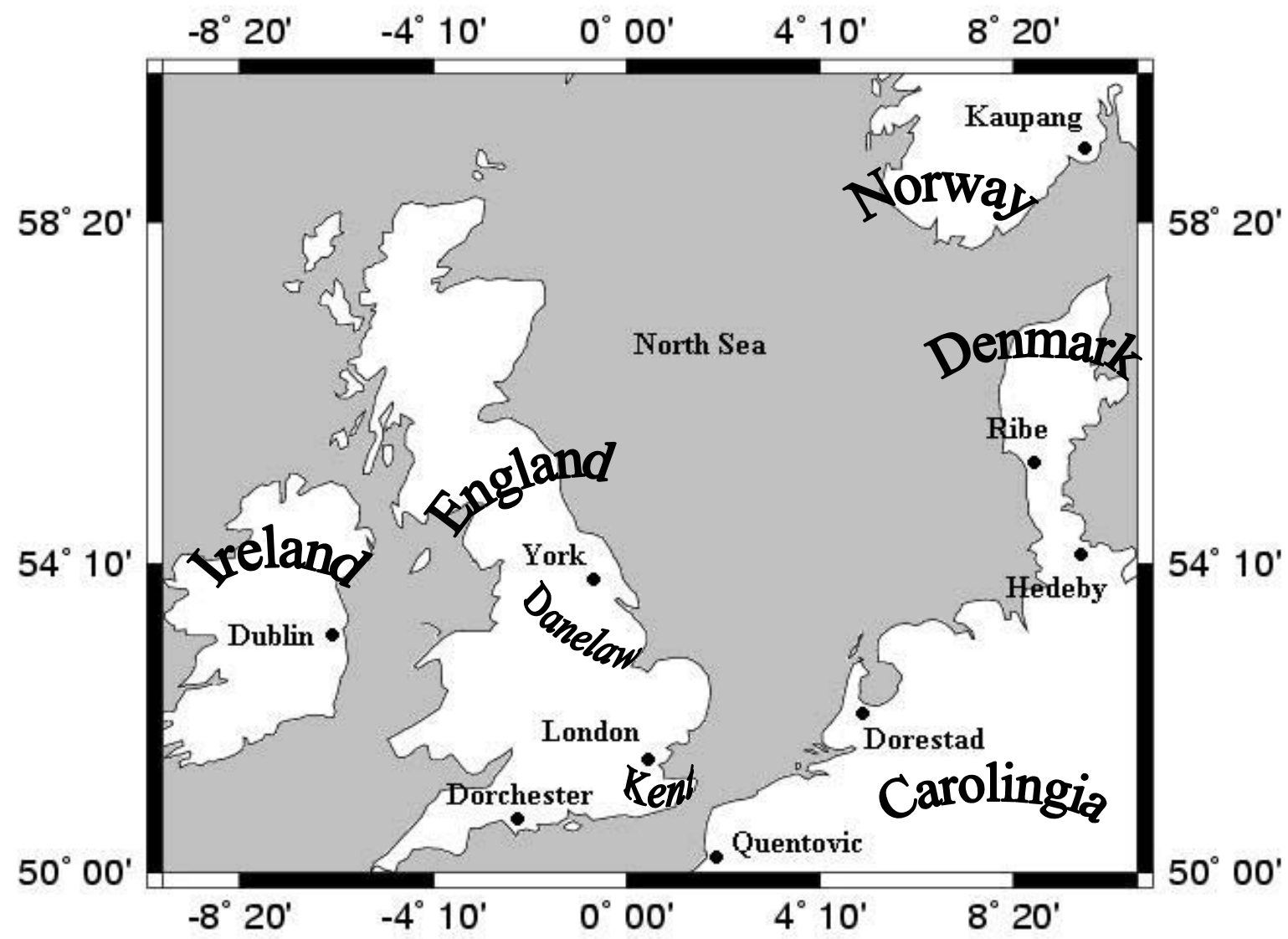

$\begin{array}{cc}\text { Legend } & \\ \text { englang } & \text { Town } \\ \text { Kenl } & \text { Territory }\end{array}$

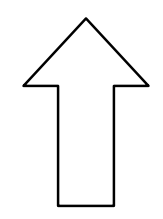

North 
Furthermore, other evidence marks England as a participant in international trade. As previously stated, glassware from Kent constituted the primary source for southern Scandinavian beads and beakers. While this does not necessarily require the presence of Scandinavian traders in England, since these items could have reached Scandinavia via gift exchange or through the continuous reselling of the item from market to market, the possibility cannot be ruled out either. Bede describes London as an international port during his lifetime (c. AD 672-731). ${ }^{76}$ As maintained by Clarke, York, as well as three other sites, had royal and ecclesiastical buildings that were supplemented by small neighboring commercial settlements by the seventh century. ${ }^{77}$

The most telling substantiation of a Scandinavian trading presence in England, however, comes from a report of the death of the King's reeve by the hands of Danish men thought to be merchants in AD 789. According to the Anglo-Saxon Chronicle, "... In these days came the first three ships of the Northmen from Horthaland. The reeve rode there, and meant to force them to the King's dwelling, because he did not know what they were; and then he was killed. Those were the first ships of Danish men to seek out the land of the English.",78

One element to notice before delving into the text itself is that archaeological evidence indicates that a system of trade between England and Scandinavia had long been functioning with some degree of complexity. The importation of Merovingian sword pommels into Scandinavia and the exportation of Scandinavian quernstones and whetstones (basic commodities) to the continent suggests direct trade contact between the

\footnotetext{
${ }^{76}$ Bede, Ecclesiastical History of the English People, edited by Bertram Colgrave and R.A.B. Mynors (Oxford: Clarendon Press, 1969), ch. 3. Clarke, Towns in the Viking Age, 15, mistakenly attributes the year in which Bede is describing events, $604 \mathrm{AD}$, as the date by which London had become an international emporium.

${ }_{77}^{71}$ Clarke, Towns in the Viking Age, 14-15.

${ }^{78}$ The Anglo-Saxon Chronicle, trans. Anne Savage (New York: St. Martins, 1983), year 789. based on versions $\mathrm{A}, \mathrm{C}, \mathrm{D}$, and $\mathrm{E}$.
} 
two from the sixth century onwards. The wide social dispersion of Kentish glassware in Scandinavia from AD 550-750 implies that they were not luxury items, but basic commodities available to any social status. Therefore, they would not have been imported by plunder, but by trade. ${ }^{79}$ Kent is one of the closest areas in England to the Frankish coast, being just across the English Channel. Direct trade with England also helps to explain the vast quantities of Kentish glassware in Scandinavia. It is likely then, that while trading along the continental coast, the Vikings had crossed the English Channel, reached Kent, and then conducted business with the English It may have been standard practice that when a merchant arrived outside the bounds of the King's limit of taxation, someone was responsible for bringing those men to the correct location. Upon recognition of this ship as a trading vessel with possible illegal intent, the reeve rode out to bring these men to justice. It is key to note that the reeve did not, "know what they were," which could mean that he didn't know their origins, but which could also mean that he did not know them to be murderers since he suspected them to be merchants. This second interpretation supports the recognition of the crew as Danish. Presumably, the reeve, or whoever reported to the reeve that a ship was making an illegal entry, knew the style of ship or manner of men that came from the north and therefore identified the Scandinavians thinking them to be like the rest of the men from the north he or she had come into contact with, namely, traders. This would explain why they were not viewed as particularly hostile and a larger armed force was not raised to dispatch them. Someone recognized the people, but did not recognize their harmful intent because up to this point, there had been none.

\footnotetext{
${ }^{79}$ For a more detailed explanation of these economic events, see Nasman,"Vendel Period Glass," 55-116.
} 
There is some difficulty in this interpretation though because the last sentence states that they were the first Danish men to seek out the lands of the English. It is also possible that the description of these events took place well after they occurred and the writer's statements reflect the prejudice he had developed for raiding Northmen. Therefore it must be determined whether or not the phrase, "to seek out the land of the English," by the writers of the Anglo Saxon Chronicle was intended to show the first violent act committed by the Northmen or their first arrival in England.

The account appears to be contemporary with the event because the killing of the king's men would be a noticeable, public, and important crime. Due to the severity of the crime, news of the assault would have quickly traveled to the appropriate authorities, who in turn would then record and investigate it. This sequence of events points to the former explanation, that of this being the first violent act and not the first contact, since the discovery of their identities must have occurred by their recognition on the spot by the people who notified the reeve or by the investigators. Even if officials pieced their identities together afterwards, enough would need to be known about the Danish, be it the style of ship they were in, their clothing, or their language, to determine that Scandinavians were the guilty party. It is therefore plausible to say that the English knew who the Vikings were because they had previous contact with them.

A later report from the Chronicle of Aethelweard which was written in the late tenth century helps to sort the matter out. In Book 3, Chapter 1 it states, “... Suddenly a not very large fleet of the Danes arrived, speedy vessels to the number of three: that was their first arrival. At the report the king's reeve, who was then in the town of Dorchester, leapt on his horse, sped to the harbor with a few men (for he thought they were merchants rather than marauders), and admonishing them in an authoritative manner, gave orders that they should be driven to the royal town. And he and his 
companions were killed by them on the spot. The name of the reeve was Beaduheard." $" 80$

This account corroborates the idea that the reeve thought that the Danes were merchants. He lends credibility to his statements by including not only the name of the reeve, but also the town outside of which the confrontation took place. Dorchester is just to the west of Kent where we have seen evidence of Viking trade. However, Aethelweard was writing from a time after the raids had begun and he drew heavily upon the Anglo Saxon Chronicle for his work. Therefore, it would seem plausible that his comment of, "that was there first arrival," was either lifted directly from the Anglo Saxon Chronicle or was also geared towards informing the reader that this was the first time the hostility began. Since it is evident that the Scandinavians had previously visited England, based on their immediate recognition as being Norse and archaeological finds, these chronicles are recording a change in activity between the English and Scandinavians. The chronicles record the first occurrence of a certain kind never witnessed before by the English. It was the first time that murderous Scandinavians had sought out the land of the English. The words also reflect that this event was the precursor of what was to come.

Another important point to remember is that no raiding accompanied these murders. If these men were marauders then why didn't they sack the city? It is hard to believe that three longboats of warriors, if that is what they were, sailed over 400 miles from their homelands to be scared off after killing a small group of men come to admonish them for parking in the wrong place! More than likely, these merchants were caught engaging in an illegal act trying as they were to import their goods without paying duties on them. Instead of being taken to the king's grounds, where they would have

\footnotetext{
${ }^{80}$ The Chronicle of Aethelweard, Book 3, Ch. 1.
} 
been fined and possibly killed for breaking the law, they chose to kill the tax collector and take their goods to another location where they could make another illegal attempt at importation or sell their goods legally.

It has become quite evident that there existed in the North and Baltic Seas an economic community capable of supporting long distance trade. For the Baltic Sea, viable market places existed in great quantities. The pattern appears to be that one major trading center for each Scandinavian region, Kaupang in Norway, Helgo in Sweden, and Hedeby in Denmark, conducted most of the international trade and were separated from one another by smaller market centers with manufacturing capabilities. Both large and small sites could therefore conduct regional trade. Examples of these smaller sites that supported long distance commerce are Loddekopinge, Ahus, Ribe, the Malaren valley in Sweden, Wolin, Grobin, Oldenburg, and Staraya Ladoga. Therefore, from the beginning of the period c. $\mathrm{AD} 600-800$, evidence has shown that the areas surrounding the Baltic Sea had become increasingly active in the long distance transportation of goods manufactured for trade.

In the rest of Europe, however, the evidence is not quite as clear. Although their importance to the North Sea trade is reflected in Charlemagne's treaty and coinage reforms as well as by their appearance in England as traders, the frequency and intensity of their voyages to these regions cannot be fully determined as of yet. It can be surmised, however, that the North Sea had become a hotbed of economic activity conducted mainly by the Frisians at first, but in which the Vikings also had an important part. There is no reason to doubt that with the opportunity available to them in these markets that the Vikings would have shied away. 
It is especially important to note that all of this mercantile activity occurred long before the raids began. Although they are most widely known for their ferocity and speed in destroying towns, reports of Viking activity c. AD 600-800 indicate that peaceful contact was not only first, but also the norm until the late eighth century.

\section{Mercantile Tactics}

Scandinavian relations with Europe were about to change, however. The arrival of the Vikings would come to be synonymous with that of raid and plunder. Many theories for this change can be imagined, but one thing is for certain, be it retaliation for the encroachment of Christianity, restriction from trading circles due to recession, or simply the realization that many of the places they had visited on their trading ventures were very wealthy and very poorly defended (especially in England and Ireland), the merchandise of northwestern Europe was now sought after by the Vikings as booty in addition to trade. Ironically, though, the economic potential of manufacture and trade was still a crucial motivator in the Viking world. In order to comprehend how plunder and trade were both part of the same function in Scandinavian practice, the "business" tactics of these individuals need to be investigated.

Othere's voyage as recorded in The Old English Orosius is an excellent example of how the Vikings operated. In it, Othere reports that there was a time when he sailed north from his homeland, of which he was the northernmost dweller, for three days. This distance was as far as whale hunters ever went. From here, he sailed another twelve days, not including the time he needed to wait for the correct winds, chiefly on account of finding more "horse-whales" (walruses) due to the money he could make from their teeth 
and hides. He states, however, that extremely dangerous hunting expeditions like this constituted only a small portion of his gains. His main revenues came from exacting tribute from the Finns which consisted of animal skins, bones, and feathers. This tribute was arranged so that everyone paid according to their wealth, the richest paying with skins of fifteen marten, five reindeer, and one bear, forty bushels of feathers, a bear or otter skin kirtle, and two ship-ropes made from whale and seal hide. Othere then set into a description of how long it took to reach the trading stations at Kaupang, stopping every night to put to shore, and from there, Hedeby. ${ }^{81}$

In this description, Othere never once mentions how the Finns came to pay him tribute, but he also never mentions exhibiting any hostility towards them. Othere implies that his trip to Kaupang was a regular occurrence so therefore it appears that Othere and his people ruled over the Finns in relative peace. The Finns were never directly under the rule of Othere, although this is also more implied than stated, but they were required to pay Othere his due. Presumably, the Finns benefited from this arrangement through protection and trade. Possible motives for this tribute payment are suggested by the similar situation in "Egil's Saga." Once a year, Thorolf went to Finnmark in order to collect his tribute and trade with its inhabitants. On this occasion, the leader of the Kven, a tribe in Finnmark, requested that Thorolf come to their aid and stop a neighboring group, the Karelians, from raiding in their land. ${ }^{82}$

It was from the Finn's tribute that Othere was able to claim that he had become a very wealthy man. Othere then took these taxes as trade on a thirty-day journey to the permanent emporia at Kaupang. From here, he took the rest of his goods (or possibly

${ }^{81}$ The Old English Orosius, Book I, Chapter I.

82 "Egil's Saga," from The Sagas of Icelanders, ed. Ornolfur Thorsson, (New York: Viking Penguin, 2000), ch. 14. 
other goods he had acquired in exchange at Kaupang) on to Hedeby. All along this journey, Othere named various groups of people whom he had made contact with. ${ }^{83}$ Presumably, since he was on a trading run, he would have done some business along the way. His use of tribute as the major portion of his trade goods is very important, however. For Othere, exacting tribute was a means of acquiring materials for transport to various markets to be sold for greater profit. Someone else lived on, owned, and worked the land for him so that he didn't have to.

Whether or not his appearance in King Alfred's court in the late $9^{\text {th }}$ century came from his actions as a tradesman or a raider cannot be readily determined though. The ninth century was a time of increased English conflict with marauders and based on reports from Saint Rimbert, which showed merchants joining marauders in an assault on a rebelling tributary, the Cori, ${ }^{84}$ his presence there is somewhat dubious. Other Vikings conducted themselves in this way. Egil Skallagrimsson and his brother Thorolf went on a spring raid and after winning a great amount of booty they set up a fortnight long truce to hold a court and trading station before returning to plundering. ${ }^{85}$ Hesitating between barter and plunder was a typical strategy for many Vikings. However, Othere's previous activities as a trader and the fact that King Alfred is mentioned as his lord, whatever the prejudices of the writer, would imply that he was currently a Norseman trading in England. Most likely, Othere was a trader by profession who came to England on business and may or may not have been involved in some piratical activity along the way.

\footnotetext{
${ }^{83}$ The Old English Orosius, Book 1, Chapter 1.

${ }^{84}$ Anskar: the Apostle of the North, 801-865, Chapter XXX.

85 "Egil's Saga," ch. 46.
} 


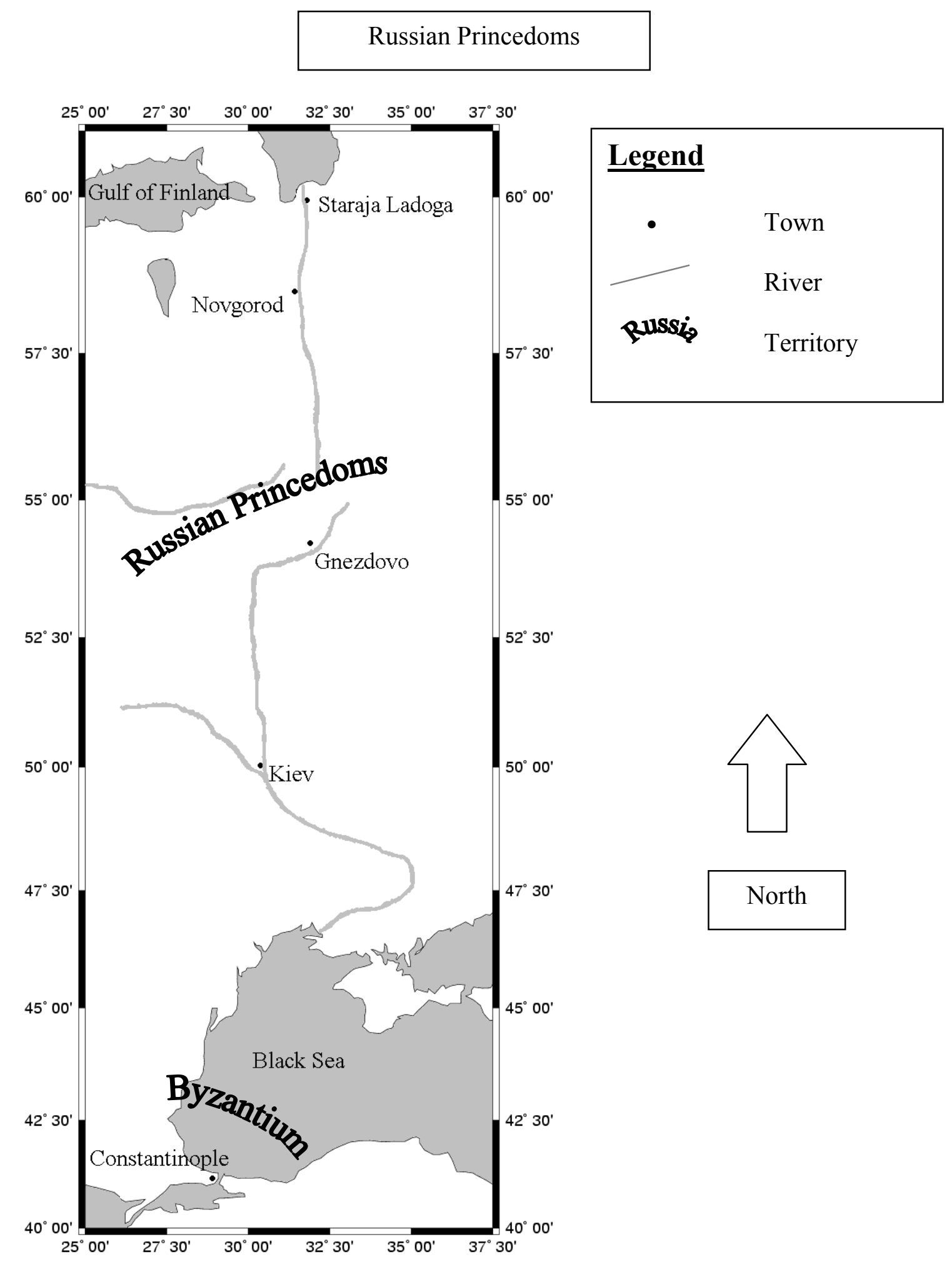


Probably the most successful example of this method of controlling the production of the land, or at least insuring that they received a share of its production, belongs to the Rus and their various tributaries along the Russian river system. ${ }^{86}$ Before it begins registering time in a year-by-year fashion, which starts in $\mathrm{AD} 859$, the Russian Primary Chronicle lists that seven races and 14 tribes were under tributary terms with the Rus, who are now thought to have been Vikings. ${ }^{87}$ In 859 , the Varangians (another name for Vikings) imposed further tribute upon the Chuds, the Slavs, the Merians, the Ves, and the Krivichians. After these tributaries rose up and drove the Varangians out of their lands, they later realized that they had no order amongst themselves and asked the Rus to return and rule over their wealthy land. ${ }^{88}$ More than likely, the author wrote this passage in order to provide a more palatable outcome than being subjugated against their will by the current ruling family. In all reality, a more likely explanation is that after the Varangians were driven out they returned and imposed themselves once again upon these tribes never to be overthrown again.

However, the chronicler was right when he stated that their land was wealthy, but perhaps not in terms of coin money. Thomas S. Noonan notes that England, France, and even their home countries in Scandinavia were wealthier than the Russians were. ${ }^{89}$ This argument is based on terms of coin money, though, and while Scandinavians may have been pursuing Islamic silver down Russian rivers to find its source, it is raw materials

\footnotetext{
${ }^{86}$ For an overview of the importance and success of the Vikings in Russia, see Hilda Roderick Ellis Davidson, The Viking road to Byzantium. (London: George Allen and Unwin Ltd., 1976) and Byzantium and Islam in Scandinavia: Acts of a Symposium at Uppsala University, June 15-16, 1996, ed. Elisabeth Piltz, (Jonsered: Paul Astroms Forlag, 1998).

${ }^{87}$ The Russian Primary Chronicle: Laurentian Text. trans. and ed. Samuel Hazzard Cross and Olgerd P. Sherbowitz-Wetzor (Cambridge, The Medieval Academy of America, 1953), Column 11.

${ }^{88}$ The Russian Primary Chronicle, years 860-862.

${ }^{89}$ Thomas S. Noonan, "Why the Vikings First Came to Russia," Jahrbucher Fur Geschichte Osteuropas 34, no. 3 (1986): 346.
} 
that would make many wealthy. Later passages reveal the preferred trading status that the Byzantine Empire conferred upon the Norse bringing their goods down the river system and into the Mediterranean world. ${ }^{90}$ While the ultimate success and organization of this river realm will be discussed later, it is important to note here that the tributaries provided an abundant source of goods and materials that the Scandinavians moved down the rivers for greater profit in the markets of the Byzantine Empire. Once again, the imposition of a tribute upon various tribes was simply a means to procure valuable materials used to acquire greater wealth through trade.

This situation wouldn't necessarily be a bad one for the tributaries, either. For starters, it provided protection. If another force threatened or attacked the group, the tax collector/lord would lose his profits. Therefore, he had to protect the region to maintain his source of materials. In addition, John Sheehan has shown that subjugated Irishmen actually profited from Norse rule in that much of Ireland's Viking age silver ended up in Irish hands due to Dublin based, Norse raiders purchasing items from Irish craftsmen after the Norse established themselves as rulers. ${ }^{91}$ Furthermore, as witnessed in the Russian Primary Chronicle, when the Viking rulers went on raiding expeditions, they invited their tributaries to come along for a share of the profits. ${ }^{92}$ However, as was previously shown with the initial expulsion of the Varangians and the rebellion of the Cori, the tributaries didn't always view it this way.

Another important aspect of Viking business acumen is their standpoint on towns and merchants. Saint Rimbert once again divulges details in this respect by reporting the

\footnotetext{
90 The Russian Primary Chronicle, years 904-907, 912, and 945.

${ }^{91}$ John Sheehan, "Early Viking Age Silver Hoards from Ireland and their Scandinavian Elements," Ireland and Scandinavia in the Early Viking Age, (Blackrock: Four Courts Press, 1998), 173.

92 The Russian Primary Chronicle, years 880-882.
} 
activities of King Anoundus from Sweden. Upon regaining his kingdom, Anoundus offered the Danes the town of Birka for their assistance because, “... it contained many rich merchants, and a large amount of goods and money." ${ }^{93}$ By his actions, Anoundus reveals that even towns were transferable commodities. It also helps to illuminate the earlier sacking of Reric in AD 808 by King Godofrid of the Danes. Later claiming to Charlemagne that he was only exacting revenge upon the Obodrites for injuries received by them, Godofrid destroyed the trading site and moved all of the merchants to Hedeby.

The Royal Frankish Annals claim that the king had an additional motive, however. They state that Godofrid took possession of the merchants because of the amount of duties the city paid because of its prominent trade and that this, the merchants and the taxes, would be of great advantage to his kingdom. ${ }^{94}$ Godofrid destroyed the city to eliminate his competition, but moved the merchants as a commodity to his own city so that he could profit from their labor. It is presumably for this act that his own men would assassinate him two years later and make a treaty with Charlemagne. In hindsight, that Godofrid was even willing to risk war with such a great power is astonishing. It is evident that he knew of the strength of the empire (and their warlike nature) from the numerous previous diplomatic contacts between the Danes and Charlemagne even before his time. This reflects the level of importance that Godofrid placed upon merchants as an asset, but also the length that he was willing to go to control trade from the Baltic into the empire and the duties they generated. Bernhard Scholz supports this theory as well. ${ }^{95}$

Under this light, enforcing tribute can be seen as a method of gaining materials for trade and manufacture. Drawing tribute, which was usually in the form of some type

\footnotetext{
${ }^{93}$ Anskar: the Apostle of the North, 801-865, Chapter XIX.

94 "Royal Frankish Annals," year 808.

${ }^{95}$ Bernhard Walter Scholz, Carolingian Chronicles (Ann Arbor: University of Michigan Press, 1970), 10.
} 
of commercial good such as fur, hides, horn and the like, was merely a means of obtaining commodities which could either be worked into more valuable trade goods or sold outright for their worth as raw material. This even extended to the use of craftsmen and towns as a commodity. The Vikings allowed people to live on the lands they conquered in relative peace as long as the inhabitants agreed to pay dues. These dues and tributes fueled their own ambitions, which oftentimes revolved around accumulating greater wealth through trade.

In many ways the system the Vikings used resembles a mafia-esque form of territory control. The ownership of these lands never came into question as they did in feudal relationships. Instead of setting up individuals to hold the land in tenure for the king, the land in these overrun areas remained in the possession of the original inhabitants. This tribute network maintained relationships where a lord allowed a village or individual to keep their lands and livelihood in return for acknowledging the lord as ruler and providing him with a portion of the gains from said livelihood. Military service and monarchial rights to all lands are removed from the equation, but there were many instances when tributaries were asked to join on missions in return for the opportunity to obtain booty for themselves. This way, the lord still had a body of men that he could draw upon in times of need, but these men were motivated by personal wealth and not by service or duty. One of the reasons this may have developed is that their culture lacked a good system for writing and recording materials, ${ }^{96}$ so they never bothered themselves

\footnotetext{
${ }^{96}$ While the runic futhark did exist during this period, its use was restricted to a very small class of literate people. Besides that, the style of writing in runes involved carving them into stone, wood, or metal and would therefore lack the record keeping capabilities necessary to maintain the transferal of property. Although some letters and deeds of sale have been found carved in bark in present day Russia, their appearance dates to the $11^{\text {th }}$ century and can therefore be deemed inconsequential to the above discussion.
} 
with the messy business of determining the possession and transferal of land during the transformation of leadership.

Therefore, overrunning a territory and becoming its ruler did not mean that the land, and more importantly the raw materials on it, automatically became possession of the ruler. In one sense, collecting tribute is the same as collecting protection money. By paying the asked sum, the Vikings provided protection for the area from other marauders. The village also received assurances that protected them from the Vikings themselves as well. In another sense, this payment was a tax levied so that the individuals could keep possession of their lands. As long as they provided the Vikings with some of the fruits of their hard work, they were able to maintain their lands and provide for their families.

As confirmed by their activities with Irish craftsmen, once the Vikings established themselves as rulers and received their tribute, they often purchased necessary items from the craftsmen proving that maintaining the economic environment was important. It may have been that it was simpler to let the inhabitants work the lands, pay a tribute, and then threaten them with violence if they failed in their duties than to put them under the yoke of direct servitude. Clarke notes that the manufacture of trade goods from areas under their control was of the utmost importance when she states that, "Metalworking, the processing of bone, antler and horn, and the production of glass beads took place in almost all Viking Age towns in all regions. Iron smithing, and in some cases smelting, were also practiced..." 97 The Vikings wanted to control trade in all its forms be it the acquisition of raw materials by imposing tribute, the transferal of those materials over long distances for an increased profit margin, or the collection of duties from craftsmen

\footnotetext{
${ }^{97}$ Clarke, Towns in the Viking Age, 158.
} 
and merchants from areas now under their authority. With this perspective in mind, the raids and conquest that occurred c. AD 800-1100 appear surprisingly different.

\section{The Continuation of Trade After the Onset of Violence}

Of greatest importance to this discussion are the events on the eastern and western fronts of Scandinavian activity. It is easier in these areas to witness the Viking contribution to the economic community due largely to the lack of unified resistance against them. In the Carolingian Empire to the south, the situation was quite different. The Empire was mostly successful in repelling would be raiders cum settlers in part due to their policy of bridge building, which effectively blocked Viking river expeditions, but mainly because the Carolingians had arguably become the mightiest military machine of the Middle Ages. The economic impact that the Vikings had in this area is less discernable, but Anskar's travels between the two via merchant ships attests to their presence as traders. He joined Swedish merchants in Frisia who were returning to Sweden so that he could spread the word of God. ${ }^{98}$ Additional instances are Godofrid's communications with Charlemagne through merchants traveling between his lands and the empire ${ }^{99}$ and that in AD 839 Rus merchants returning from Constantinople are recorded in the Annals of St. Bertin as having asked King Louis the Pious for safe journey through his territory. ${ }^{100}$

It is with these daring merchants that the study of Scandinavian eastern contacts must begin. That shiploads of men were willing to brave the long journey, the dangerous

\footnotetext{
${ }^{98}$ Anskar: the Apostle of the North, 801-865, Chapter X.

99 "Royal Frankish Annals," year 809.

100 Annals of St. Bertin, trans. Janet L. Nelson (Manchester, Englend: Manchester University Press, 1991), year 839 .
} 
rapids of Russian rivers, the arduous task of moving the ships and merchandise over land to connect with the next river, and the constant threat of enemy attack is a testament to the lengths that Scandinavians were willing to go in the name of trade.

As has already been mentioned, Scandinavians were "asked" to come and rule over the tribes of the northern Russian river system in the middle of the $9^{\text {th }}$ century. Their reign was concentrated on what would become in their hands the commercial centers of this budding region. These centers stretched from Staraya Ladoga in the north, to Novgorod, then to Gnezdovo, and finally on to the last Rus controlled trading site of the rivers, Kiev. There evidence also links Viking exploits down the Volga River and into the Caspian Sea. ${ }^{101}$ While there is no doubt these settlements existed before the onset of Scandinavian rule, what is significant is the growth and direction of these sites after it is established. Clarke observed that before the end of the $9^{\text {th }}$ century, Staraya Ladoga and Gnezdovo may have contained craft centers, but by the end of the $10^{\text {th }}$ they were important urban settlements in their own right. ${ }^{102}$ Novgorod had become not only a center of administration, but a major trading post as well. ${ }^{103}$ As for Kiev, Davidson notes that the Rus built this small town into a large trading center. ${ }^{104}$ The Russian Primary Chronicle supports this notion as it originally describes Kiev as a small city on a hill and later claims that it is the, "mother of all Russian cities.",105

Once the Vikings were in charge, the territories under their control experienced an economic boom that found its way back up the rivers as well. Kromann and Jensen,

\footnotetext{
${ }^{101}$ John Haywood, The Penguin Historical Atlas of the Vikings (New York, NY: Penguin Group, 1995), 109.

${ }^{102}$ Clarke, Towns in the Viking Age, 122-124.

${ }^{103}$ Martina Stein-Wilkeshuis, "Legal Prescriptions on Manslaughter and Injury in a Viking Age Treaty Between Constantinople and Northern Merchants," Scandinavian Journal of History 19, no. 1 (1994): 6. ${ }^{104}$ Davidson, The Viking road to Byzantium, 74.

${ }^{105}$ Russian Primary Chronicle, years $860-862$ and 880-882 respectively.
} 
however, doubt the importance of trade as the primary means of income, stating that the influx of money into the north by way of Russia was from plunder. ${ }^{106}$ Their statement would seem erroneous since oriental coins didn't arrive in Scandinavia in any significant amount until after AD 850, ${ }^{107}$ which is the approximate inception of Viking rule, and since regular long distance trade is indicated by the over 80,000 coins that do make it into Scandinavia. ${ }^{108}$ Furthermore, there are many references from the Viking Age that point to trade as the Rus' primary means of wealth. Elizabeth Piltz has been especially dedicated in this regard, providing many archaeological clues that expose the trading nature of not only the Rus, but their northern neighbors in Scandinavia as well. An engraved whetstone from c. AD 1000 in Gotland records the travels of a krikfara, a small group of men comprised of specialized commercial travelers, which made ventures to Ormica, Ulvair, Greece, Jerusalem, Iceland, and Serkland. ${ }^{109}$ It is merely one of the thirty-three runic carvings that indicate visits to Greece by similar krikfara. In fact, Piltz claims that the use of the term farmadr, which is a Scandinavian peasant specializing in long distance trade, demonstrates the continued existence of trade as a viable means of support. ${ }^{110}$

An additional factor in realizing the significance of trade to the Rus is the importance of that trade to their clients, the most predominant one being the Byzantine

\footnotetext{
${ }^{106}$ Anne Kromann and Jorgen Steen Jensen, "Cufic coins in Denmark," Byzantium and Islam in Scandinavia: Acts of a Symposium at Uppsala University, June 15-16, 1996, ed. Elisabeth Piltz (Jonsered: Paul Astroms Forlag, 1998), 72.

${ }^{107}$ Peter Sawyer, "Birka, the Baltic, and Beyond," Society and Trade in the Baltic during the Viking Age. ed. Sven-Olaf Lindquist (Visby: Gotlands Fornsal, 1985), 166.

${ }^{108}$ Elisabeth Piltz, "Byzantium and Islam in Scandinavia," Byzantium and Islam in Scandinavia: Acts of a Symposium at Uppsala University, June 15-16, 1996, ed. Elisabeth Piltz (Jonsered: Paul Astroms Forlag, 1998), 29.

${ }^{109}$ Piltz, "Byzantium and Islam in Scandinavia," 28.

${ }^{110}$ Elisabeth Piltz, "Varangian Companies for Long Distance Trade," Byzantium and Islam in Scandinavia: Acts of a Symposium at Uppsala University, June 15-16, 1996, ed. Elisabeth Piltz (Jonsered: Paul Astroms Forlag, 1998), 90.
} 
Empire. The Russian Primary Chronicle records that in the years between AD 863-866 the Rus attacked the Greeks with disastrous results. In AD 904-907, Oleg, the leader of the Rus, attacked the Greeks again, demanding that they pay his force of two thousand ships, reckoned at 40 men per ship, at a rate of twelve grivny per man. Soon, the Greek Emperors and Oleg concluded a trading treaty. In order to protect themselves, the Greeks declared that those who traded must enter the city unarmed through a specific gate, that during their stay they must reside in a specific quarter of the city, and that then and only then may they conduct their business with the bonus of paying no taxes. Duty free business alone is a special privilege. However, the Greeks also yielded to Oleg's demands that whosoever of his men that came as merchants would receive supplies for six months (including bread, wine, meat, fish, and fruit), unlimited baths, as well as whatever would be needed for the journey home, specifically, food, anchors, cordage, and sails. $^{111}$

Although this appears like a lot, its volume is tempered by the fact that Oleg and his men had just ravaged the area surrounding Constantinople. The Greeks were more than likely trying to buy off these invaders to prevent them from causing any more destruction. However, in the next year, they ratified the treaty with additional provisions concerning lost cargo and manslaughter. This then implies that the Greeks were willing to maintain this preferred trading status because they are defining legal issues that would become or already had become pertinent to the Rus' stay with this revision. If the Greeks were willing to put up with the threat of attack on more than one occasion just to maintain trading relations, trade with the Rus must have been important and substantial.

\footnotetext{
${ }^{111}$ Russian Primary Chronicle, years 904-907.
} 
The Rus would test the limits of the Greek need for northern goods further still. In the years of AD 935-941 it is recorded in the Russian Primary Chronicle that Igor, who had succeeded his father Oleg, attacked Constantinople once again. To Igor's dismay, the Greeks used Greek fire upon his men and the Rus were routed. Not to be defeated, Igor collected another great army and marched upon Constantinople in AD 944. In order to avoid further conflict, the Emperor offered Igor the same tribute that his father had received plus an additional amount. The next year, the Emperor sent his messengers to confirm the treaty, but added that to further distinguish peaceful Rus from raiders, merchants and agents of Igor were required to carry seals to mark their position. Agents of the prince carried gold seals and merchants carried silver ones. A document from the prince stating the number of ships that originally departed from Russian territory accompanied these seals. Two of such seals, most probably attached to documents permitting the export of silk, were recovered in Sigtuna and date to the $11^{\text {th }}$ century. ${ }^{112}$ That the Byzantine Empire would be willing go to such lengths to maintain good trading relations with the Rus is an enduring comment on how much they valued their business.

The situation in the far-northwestern world was considerably different, though, especially in Iceland. Discovered around AD 860 by Norwegian sailors who were blown off course from their destination of the Faeroe Islands, Iceland contained no indigenous population on whom the Scandinavians could impose tribute. Since there were no inhabitants, except for the possibility of a few hermetic Irish monks, the Vikings immediately began settling this once forested island. The settlers, however, obliterated the forests in order to build farms and provide fuel for the iron smelting industry. Kevin Smith has found evidence recently that the specialized production of iron from only one

\footnotetext{
${ }^{112}$ Piltz, "Byzantium and Islam in Scandinavia," 30.
} 
site's worth of slag represented enough production to satisfy the needs of a single farm for thirty to fifty years. ${ }^{113}$ These large quantities suggest that the inhabitants exploited iron for trade.

In addition, there are multiple references to traders traveling to and from Iceland. The most telling reference in regards to the Viking attitude towards trading versus raiding appears in "Egil's Saga." Brynjolf, a somewhat powerful landholder in Iceland, had a mischievous son by the name of Bjorn. Bjorn asked what many young Vikings in the sagas asked of their fathers, that he be given a longship and crew to go raiding during the summer. Brynjolf's response was,

"You cannot expect me to let you have a warship and big crew of men because for all I know you might turn up where I would least prefer you to. You have caused enough trouble as it is. I will let you have a trading ship and cargo. Go to Dublin, which is the most illustrious journey anyone can make at present. I will arrange a good crew to go with you." 114

Brynjolf's statements imply that although it was expected for him to equip his son for a raid, he was not going to do so because he could not trust his son's good judgment. He would, however, provide the next best thing for him which was a ship full of cargo. In this way, Bjorn could still be active and make a profit.

Since the hero of the saga, Egil, was soon to fight alongside of the English King Aethelstan in England, this portion of the saga must have taken place in the early 900's. This is well after the Viking raids had commenced in earnest, thus it fits well as a signal of Viking activity and attitudes towards trade during the heart of the Viking age. Brynjolf implies that raiding was preferred to trading as a means to make a living.

\footnotetext{
${ }^{113}$ Kevin P. Smith, "Landnam: the settlement of Iceland in archaeological and historical perspective," World Archaeology 26, no. 3 (Feb. 1995): 334-335.

114 "Egil's Saga," ch. 32.
} 
However, he also indicates by the end of his explanation that trading could still be worthwhile by the use of the phrase, "illustrious journey."

Supporting this view is the Saga of Harald Finehair. It tells of one of Harald's sons, Bjorn, who was ruling in the Vestfold of Norway sometime in the AD 920's. It states that Bjorn,

“... engaged little in warfare. Many merchant ships frequented Tunsberg (where he lived and was earl), both such from Vik and such from the northern part of the country, as well as ships from the south, from Denmark and Saxland. King Bjorn also owned merchantmen that sailed to other lands and thus acquired for himself things of value and other wares which he deemed he needed. His brothers called him a chapman or a merchant." 115

The comment that Bjorn "engaged little in warfare," appears even to the writers of the sagas to be a little suspect. They felt that his behavior was out of the norm for this time because nearly everyone participated in raids. They do mention later on that he was a good ruler, but the defining characteristic of Bjorn was that he was predominately involved in the affairs of merchants and not in plunder. It is especially important to note the extent of Bjorn's contact. Not only was he participating in regional trade within Norway, but also sent ships to many other foreign lands and had merchants from Denmark and Saxony frequent his docks.

These statements indicate that the saga writers felt that rulers of this time were more prone to back raiding expeditions than trading ones. However, it is also obvious that many powerful men still found trading a viable means to earn wealth. In this view, trade can still be an important aspect of a king's ability to rule. Raiding may indeed have been the predominant activity for rulers in the saga writers' minds, but trade was still a

\footnotetext{
${ }^{115}$ Snorri Sturluson, "The Saga of Harald Finehair," Heimskringla: The History of the Kings of Norway, trans. Lee M. Hollander (Austin: University of Texas Press, 1964), ch. 35.
} 
worthwhile alternative. Indeed, trade was the primary motive for sending many ships to foreign countries. These trading ships served Scandinavian expansion by extending Norse influence and participation in foreign countries and their markets.

Other more settled areas, such as Ireland, experienced different circumstances, but the result, the exploitation of the territory for the production of and eventual domination over trade and trade goods, as well as the resultant expansion, remained the same. It is believed that Norse settlement on the Irish Sea began c. AD 800. ${ }^{116}$ By AD 847, the Vikings had made the Irish regular tribute payers and had taken control of the neighboring islands. ${ }^{117}$ Although it is debatable whether towns, or at least trading centers of any size, actually existed before the arrival of the Vikings, one thing is certain. By the end of the ninth century, Viking controlled Dublin can be said to have been a center of commerce and industry, based on the presence of Byzantine silk hairnets, Baltic amber, craft materials, and the later discovery of a Viking ship constructed in Ireland but sunk in Denmark c. AD 1060, and not just a defended stronghold. ${ }^{118}$ Building a boat requires special tools, such as the adze, which resembles a small hand-axe, but is angled to one side and used like a scoop, and special craftsmen. Blacksmiths and boat builders in the area would have benefited from this project.

As noted earlier, Sheehan has argued that the availability of silver for Irish craftsmen increased dramatically during the Viking Age. The Irish then worked this silver into armrings and ornaments and either sold them back to the Vikings or used them to seal military alliances with them. In this way, Irish crafted items like this made their

\footnotetext{
${ }^{116}$ James Graham-Campbell, "The Early Viking Age in the Irish Sea Area," Ireland and Scandinavia in the Early Viking Age (Portland, OR: Four Courts Press, 1998), 104.

${ }_{117}$ Annals of St. Bertin, 847.

${ }^{118}$ Clarke, Towns in the Viking Age, 106.
} 
way into the international market. Brynjolf's earlier statements that Dublin was, "the most illustrious journey that anyone could make at present," although most likely exaggerated to reflect the area's importance to fourteenth century Iceland, still argues for the predominance of Dublin as a trading station. Mary Valante goes so far as to suggest that by the $11^{\text {th }}$ century Irish kings had realized that, “....in order to control Ireland's trade and wealth they had to control Viking Dublin."119 This realization may be what led to the numerous bouts for control of the Dublin kingdom.

Confrontation marks the Scandinavian presence in England for the period c. AD 800-1100. The Anglo-Saxon Chronicle reports continual raiding from AD 835 until their eventual expulsion in AD 1042. However, by AD 876 the initial invaders had turned to settlement in northern England. Jones asserts that this was due to diminishing returns from pillaging, ${ }^{120}$ but it is possible that there were other motivations as well, specifically, those of business enterprise. As Jones himself states, the accelerated economic growth of the area is attested by the fact that later Danegeld demands increased sharply over time from 10,000 lbs of silver in $\mathrm{AD} 991$ to $30,000 \mathrm{lbs}$ of silver in $\mathrm{AD} 1007 .{ }^{121}$ Add to this the fact that the Danelaw was established c. AD 880 as well as the notion that an, "Anglo-Danish England gradually emerged from the devastation of war, its character shaped by the surprisingly peaceful mingling of former enemies," ${ }^{122}$ and what becomes apparent is a lull in hostilities geared towards economic production. For instance, archaeological evidence indicates that many of the towns included in the Danelaw experienced a period of growth hitherto unheard of in their history under English control.

\footnotetext{
${ }^{119}$ Valante, "Reassessing the Irish Monastic Town," 11-12.

120 Jones, "Market Economy," 668.

121 Jones, "Market Economy," 674.

${ }^{122}$ Anne Savage, The Anglo-Saxon Chronicle (New York: St. Martins, 1983), 101.
} 
The Scandinavians conquered York, changed the street system, which helped to alter the commercial emphasis of the town, and moved the economic center to Coppergate. Here excavations have revealed that between AD 925 and 975 a great variety of metalworking was conducted in iron, silver, lead, copper, and gold and that everyday objects such as knives and cheap jewelry were being mass produced. ${ }^{123}$ Furthermore, York's hinterland supported its economy as well as its long distance trade connections suggesting that the Vikings were incorporating the entire area into their plans and not just focusing on the urban centers. $^{124}$

York is not the only existing center that benefited from a Viking makeover, though. Lincoln, one of the most prosperous towns in the Danelaw, could boast of increased long distance contacts which archaeological remains have revealed stretched from the Rhineland, the Mediterranean, North Syria, and even China. ${ }^{125}$ Its area expanded as well. Digs at Flaxengate have determined that from AD 400 until 900, this portion of the town remained unused. During Viking dominance, however, rulers laid down new streets and erected wooden buildings to accommodate the influx of people. ${ }^{126}$ While Jones believes that the increase in the wealth and size of Lincoln was the result of merely the extended trade connections, ${ }^{127}$ Clarke has shown that its manufacturing capabilities also played a large part in its expansion due to its production of glass beads, glass finger rings, and combs. ${ }^{128}$ Many other towns, such as Norwich, Thetford, and the nearly 100 other market towns developing in this period, demonstrate this increased

\footnotetext{
${ }^{123}$ Hall, "The Vikings as Town-Dwellers," 33.

${ }^{124}$ Ibid., 33 and Clarke, Towns in the Viking Age, 96.

${ }^{125}$ Hall, "The Vikings as Town-Dwellers," 32.

${ }^{126}$ Ibid., 32.

127 Jones, "Market Economy," 661.

${ }^{128}$ Clarke, Towns in the Viking Age, 99.
} 
population and area as well as heightened capacities for trade and manufacture. The increase in size, population, and manufacturing opportunities of Scandinavian towns abroad suggests that wealth earned through trade was a motivation for Viking expansion.

Surprisingly, though, most scholars are reluctant to give credit to the Vikings for their urban achievements in England. At best, scholars recognize that the Vikings were the impetus behind the economic movement but that English endeavors, whether they were the creation of burhs in response to Viking attacks, the breaking of the established order and its reformation under duress, or the fundamental changes in English institutions, ${ }^{129}$ have received the accolades for progress. Since in comparison the Danish towns grew more rapidly than their English counterparts during this period, ${ }^{130}$ however, it logically follows that their success was largely due to Danish control tactics. These tactics, such as utilizing their extensive trading network and establishing or broadening manufacturing centers which were primarily populated by the influx of Scandinavians willing to work for a profit, brought these towns into the sphere of the international market and provided more valuable items for trade in this expanded market. This combination gave Danish towns an economic edge that allowed them to prosper far more than their English counterparts.

Throughout the entire course of time covered here, one thing has remained constant: the Scandinavian interest in continued participation in long distance trade. In the period c. AD $600-800$, just before the Vikings truly flourished, an economic community prospered in two regions of northern Europe that could and did support the existence of regular long distance traders. Both areas boast a number of permanent and

\footnotetext{
${ }^{129}$ Clarke, Towns in the Viking Age, 91, Hall, "The Vikings as Town-Dwellers," 34, and Jones, "Market Economy," 658 respectively.

${ }^{130}$ Jones, "Market Economy," 672.
} 
seasonal emporia which indicates enough commerce to support regular trade. Literary records and archaeological remains testify to a proliferation of Scandinavian participants in this endeavor.

The first region, centered around the Baltic Sea, shows extensive evidence of Scandinavian merchant activity in the transportation of luxury items such as furs, slaves, and precious metals, and to a lesser degree basic commodities like combs, glass vessels, and hone stones across regional and international boundaries. This strongly supports the presence of many Scandinavian merchants, hauling goods over long distances for profit. The other economic region was located around the North Sea. While the evidence is not as compelling as for the Baltic Sea, it is evident that Scandinavian traders operated throughout Frisia and up the English coast.

By studying the nature of these merchant's tactics it is apparent that even in later years, after they realized that their strength and speed were great enough to impose their rule upon other portions of Europe, long distance trade was still of great importance. This cyclical nature can be described as follows: Initial trading contact provided first luxury then commodity items as well as military intelligence. International and regional trade was used primarily to generate revenues which could then finance raids on areas determined to be weaker. Raids earned rulers immediate profit while gaining power for them by establishing Scandinavian rule over a territory. Once their rule had been established a tribute was imposed which, along with the Scandinavian policy of increasing the manufacturing capabilities of captured foreign towns, provided materials that were sold through long distance trade routes for an even greater profit. This trade in turn provided further opportunity to make money, evaluate the strength of competition, 
and so on as the cycle continued. This is not to say that spying on events in foreign lands was always a conscious activity on the minds of traders, though.

However, this does happen in the sagas. The "Saga of Olaf Tryggvason," reports that Earl Hakon sent his men on a merchant mission to Dublin. His men where to play the part of merchants unless they found that Ali, a friend of the Irish king, was actually Olaf. In that event, they should forgo their merchant duties, capture Olaf, and return to Earl Hakon. ${ }^{131}$ Trade was one means of communication between two lands that resulted from contact. One can imagine that rulers who had powerful ambitions would likely use merchant's reports as surveillance, but the average trader did not need to know that they were acting as spies. More often than not, the trader's activities and intentions were geared towards the selling or acquisition of goods to support his or his lord's venture.

It is evident that these tactics were in use during the Viking Age (c. AD $800-$ 1100), especially in Russia and England. As the Viking presence became more permanent in both of these areas, trading and manufacturing capacities of urban centers underwent a marked growth. That goods from as far as China and India have been found scattered across the whole of Viking Europe, demonstrates the reach, dispersion, and maintenance of their long distance contacts. It stands to reason by the sheer volume of materials that have been determined to be intended for trade and were transported to and from foreign lands, that a significant number of Vikings must have left their rural lives and traveled abroad for peaceful trade. Therefore, archaeological remains and textual evidence confirm that due to their extensive participation in the economic market, their tactics of and continued interest in trade, and their actions once they conquered new

\footnotetext{
${ }^{131}$ Snorri Sturluson, "The Saga of Olaf Tryvaggson," Heimskringla: History of the Kings of Norway, trans. Lee M. Hollander (Austin: University of Texas Press, 1964), ch. 46.
} 
territories, one significant factor of Viking expansion was the desire to earn a living through trade.

\section{Section Two: Mercenary Employment}

One cannot ignore, however, the emphasis that Vikings placed on wealth gained by force alone. The chronicles and annals of medieval Europe are rife with Viking raids conducted for plunder's sake. Attached to these raids are the obvious political motivations for high-ranking nobles, chieftains, and kings. This aspect of raid is discussed in the next chapter. For the rest of the Vikings, though, participating in raids was a matter of employment and opportunity. It was in this way that the individual earned the opportunity to improve not only his standard of living, but also to acquire fame and fortune, necessary in the Scandinavian world for increasing his social standing.

There were two separate levels operating in regards to the concept of Vikings as mercenaries, though. Men of low status existed on the first level. These men may or may not have owned land. It is safe to suppose that they also lacked a ship due to its high cost of construction, operation, and maintenance. With these men, raiding was distinctly an economic opportunity designed to earn them money or valuable goods in exchange for the shedding of blood. They fought for a leader for some form of pay. The second level, however, contained men who were of lesser noble status.

More than likely, these men owned land and could procure the use of a ship for their own designs if they did not own one outright. The motives of lesser nobles are more difficult to separate. Since they had access to ships and could potentially raise men to fight for them, they were employers. In this guise, their motives were a desire to increase 
personal wealth and status. They were fighting for personal gain. However, sources indicate, as will be shown momentarily, that these men also hired themselves and their crews out to more powerful nobles in exchange for some form of payment. This aspect indicates that raiding was employment for them as well. Even though they had gathered men on their own, the lesser nobles' services, and therefore the service of the men on their ships, were available for hire. Lesser nobles were the contractors of the medieval world, accumulating workers for themselves which could be hired out to larger forces when they so chose. These men provide not only an economic bridge between the upper and lower classes, but also a motivational one as well. On one hand, they were employed by others to participate in raids just like "common" Vikings. This would reflect their desire for personal wealth. On the other hand, if their purpose was political, say the conquest of a territory, their motives fall in with that of kings and greater nobles. This would reflect their desire for political gain and therefore discussions of this nature belong within the next chapter. It is evident, however, that throughout Europe, the Russian kingdoms, and the Byzantine Empire, Scandinavians, whether great or small of status, were in demand for their skills as men-at-arms.

\section{Scandinavian Employers}

In the "Saga of Grettir the Strong," a ship from Norway brought news that the Norwegian crown had recently changed hands in favor of Olaf Haraldsson. ${ }^{132}$ This excited Grettir and other young warriors because Olaf gave the warmest welcome to accomplished men and took them into his service with great pay. Not only could Grettir

\footnotetext{
132 "The Saga of Grettir the Strong," The complete Sagas of Icelanders, vol. II, ed. Vidar Hreinsson, (Reykjavik, Iceland: Leifur Eiriksson Publishing, 1997), ch. 37.
} 
and these men expect to be clothed, fed, and given shelter (which are forms of payment), but they could also expect to gain riches by partaking in the plunder from raids that Olaf sponsored. As Niels Lund states,

"Magnates as well as lesser vassals were surrounded by followings of fighting men whose standard of living depended on their success in war. They were not beneficed but lived from stipendia; they were fed and clothed by their lord, provided with weapons by him, and, following victorious campaigns, rewarded with golden armrings, silken clothes and other valuable and prestigious items."133

Items like swords, rings, armrings, and expensive clothes were then worn in a conspicuous display to demonstrate not only the wearer's worth economically, but also socially. Many men were able to make a living this way since it was custom for important people to keep armed retinues in constant employment. Skallagrim, although just a chieftain of a few farms in Iceland, kept no less than sixty armed men with him at all times. ${ }^{134}$ This means of service, which began centuries before, developed into the system of feudal relationships that most scholars commonly associate with the medieval world.

This method of employment did have its drawbacks. In AD 945, the princely retinue of Igor, prince of Kiev, goaded him into attacking a neighboring group called the Dereva on grounds of unfair pay. ${ }^{135}$ The Prince's men felt that the rewards given by another lord to his retinue were more valuable than the ones they received. In order to keep his men from seeking employment elsewhere, Igor heeded their pleas. Their plan backfired. After successfully attacking the Dereva and leaving with tribute, Igor sent the followers he had hired to swell his ranks home and returned with just his retinue to feed

\footnotetext{
${ }^{133}$ Neils Lund, "Allies of God or Man - The Viking Expansion in a European Perspective," ViatorMedieval and Renaissance Studies 20 (1989), 54.

134 "Egil's Saga," ch. 34.

${ }^{135}$ Russian Primary Chronicle, year 945.
} 
their greed. Igor and all his men died in the ensuing battle with the remnants of the Dereva force.

As is evidenced from the previous example, rulers could not afford to maintain an armed retinue large enough to suit all of their political desires, especially when they encompassed conquest or unification. In order to fulfill these needs, leaders recruited from the surrounding countryside and beyond to raise an army. The reward to these men for participating in the lord's venture was a cut of the plundered profits. In this way, men who were not directly involved in a lord's service had a chance at earning great wealth and therefore providing for their own and their family's security. One need only look in the Russian Primary Chronicle to see that Scandinavians enticed their tributaries to join them in many raids, usually conducted against the Byzantine Empire, due to the possibility of plundered wealth.

Other instances of raid conducted for pay abounds. In the mid-ninth century, King Anound of Sweden offered the crew of twenty-one Danish merchant ships the market town of Birka as plunder if they agreed to assist him in regaining his throne. ${ }^{136}$ Although Anound eventually recanted his promise by offering the Danes a smaller, less important town as a replacement, this shows the stakes involved in fighting for pay as a mercenary. There are also instances where the scale is not so grand. In "Egil's Saga," Egil and his brother Thorolf equip a few longships given to them by their father and employ a crew so that they could go raiding in the Baltic. ${ }^{137}$ Their father Skallagrim had enough money to provide his sons with this opportunity to try to make something of themselves. In doing so, Skallagrim was also providing work for those brave enough to

\footnotetext{
${ }^{136}$ Anskar: the Apostle of the North, 801-865, Chapter XIX.

137،"Egil's Saga," ch. 46.
} 
accompany them into battle. These examples, the volume of raids mentioned by chroniclers of the time, and the fact that the raids were often perpetrated by Vikings unaffiliated with the "official" power of the land, also demonstrated the relative ease by which a Scandinavian ruler, no matter how small in the overall power scale, could raise an able bodied and willing army of men to go to work for him.

Thus far, the references made towards work have generally reflected internal Scandinavian raiding. While a Swede hiring a Dane to help him win back his kingdom may not be a motive for external expansion, it does allow us to better understand the mechanics of raiding as a function of employment. With this in mind, investigating the motive of foreign raids becomes surprisingly different.

There is no doubt that when the Great Army arrived on English shores in AD 865 that settlement and conquest was their agenda. That this hunger for land was also a response to a population increase in the Scandinavian homeland is also evident. ${ }^{138}$ Indeed, within eleven years the invaders had settled down and were sharing out the land amongst themselves. ${ }^{139}$ However, what is also clear during this period and beyond is that although some of the raiders were settling down, many more were still actively marauding. In the next year alone, one hundred twenty Viking ships were lost at sea when a storm caught men who were intending to continue sacking the countryside. Although there was land to be had, one hundred twenty shiploads of men were still willing to be employed by various petty rulers for a chance to earn more pay by plunder. In the successive years, the Great Army would continue to raid, occasionally splitting their forces and sharing out land to those who had finished their time as mercenaries.

\footnotetext{
${ }^{138}$ See previous, 3-9.

${ }^{139}$ Anglo-Saxon Chronicle, years 865-876.
} 
The ones who remained, however, either continued to raid in order to accumulate more wealth or struck out for home to use the wealth they had earned to improve their standard of living. Raiding for these warriors was a way to earn a living.

\section{Christian Employers of Medieval Europe}

Scandinavian rulers were not the only ones to employ the Vikings in this way. In fact, Viking warriors were continually for hire throughout all of Christendom and the entire span of the Viking Age. One of the greatest employers of Viking men was the Carolingian Empire.

The earliest recorded instance of this practice occurs by Lothar in AD 841. The Annals of St. Bertin states, "Lothar, to secure the services of Harald (Harald Klak, deposed ruler of Denmark), ..., to the damage of Lothar's father's interests and the furtherance of his own, now granted him Walcheren and the neighboring regions as a benefice." ${ }^{140}$ Lothar had hired Harald to harass the Frisian coast, in particular Dorestad, in order to keep his father Louis from focusing all of his attentions on his rebelling son's actions in the south. ${ }^{141}$ He would continue this policy by extending similar privilege to Klak's son Godfred whom he had known from Godfred's baptism in Mainz in AD 826. This would however prove unwise due to Godfred's defection and subsequent raiding of Dorestad for his own gain. ${ }^{142}$

Lothar was not the only member of Carolingian royalty willing to bring Vikings into their service. Pippin of Aquitaine would utilize Nordic might on multiple

\footnotetext{
${ }^{140}$ Annals of St. Bertin, year 841.

${ }^{141}$ For more on this, see 87-88.

${ }^{142}$ Annals of St. Bertin, year 852.
} 
occasions. ${ }^{143}$ So would Carloman and Louis the Younger. ${ }^{144}$ Of particular interest to this discussion are the events that followed Charles the Bald's decision in AD 860 to hire a group of Vikings marauding on the Somme, led by the chieftain Weland, to expel another group of Vikings marauding on the Seine. ${ }^{145}$ However, while obtaining the 3,000 lbs of silver to pay them, Weland and his crew of 200 ships went to raid elsewhere, albeit unsuccessfully. According to the Anglo-Saxon Chronicle, King Aethelberht fought off a great ship force attacking Winchester in AD 860. ${ }^{146}$ This was most likely Weland's band. Upon returning to Francia in AD 861 after this loss, Weland then received 5,000 lbs of silver, livestock, and grain to do the job for Charles as promised. The following year, Weland disbanded his command, commended himself to Charles, and entered into his service. Weland's actions attest to the dichotomy inherent in the actions of lesser nobles. By hiring 200 ships worth of men to go raiding in England and Carolingia, he is providing an economic opportunity for his men. Weland was their employer and they were hired to fight for him. When he accepts Charles' offer of 5,000 lbs of silver and more, however, Weland proves that he was willing to fight for pay as well. Thus, he was the employed.

During all of this, Robert, the Count of Angers, was trying to suppress a rebellion by Salomon, Duke of the Bretons. After Weland entered the service of Charles and disbanded his force, the fleet split into smaller groups and went their separate ways. The annals report that Salomon hired many of these, along with other Vikings who had been raiding in Spain, to use against Robert. Salomon hired an additional twelve Danish ships,

\footnotetext{
143 Annals of St. Bertin, years 859 and 864.

${ }^{144}$ Annals of St. Bertin, year 861 and Annals of Fulda, trans. Timothy Reuter (New York: Manchester University Press, 1992), year 866.

${ }^{145}$ Annals of St. Bertin, year 860.

${ }^{146}$ The Anglo Saxon Chronicle, trans. G.N. Garmonsway (New York: Dutton, 1965), year 860, version A.
} 
but Robert caught and slew them on the river Loire. In response to these developments, Robert made an alliance for 6,000 lbs of silver with some sixty Viking ships that had been on the Seine before Salomon could hire them and use them against him. Viking mercenaries were in demand.

The most famous, successful, and lasting memory of a Viking mercenary in the Carolingian Empire though, is Rollo (Hrolf) Ganger. According to the "Saga of Harald Finehair," Harald declared Rollo an outlaw for raiding in Norwegian lands. ${ }^{147}$ Eventually, after leaving the area and raiding abroad, Rollo and his men ended up in Francia where in AD 911 King Charles the Simple hired them. In exchange for their homage, conversion to Christianity, and pledge to keep other Norsemen from gaining access to the interior via the Seine, Rollo was made Count of Rouen. This land eventually became known as Normandy and was the only lasting fief gained by any of the Norse mercenaries. Although Rollo would enter into Carolingian politics, which therefore ends his participation in simple, economic employment, Charles had hired Rollo and his entire crew to be the bodyguards of the Seine against further Viking attacks.

England was also responsible for hiring its fair share of Viking warriors on both the large and small scale. In "Egil's Saga," Egil and his brother Thorolf, along with the three hundred men they had under their command, sought out King Athelstan because they heard that his rivals were preparing to attack him. It states, "But King Athelstan mustered an army, and paid anyone who wanted to enter his service, English and foreign alike."148 It continues by saying that King Athelstan,

\footnotetext{
${ }^{147}$ Sturluson, "The Saga of Harald Finehair," ch. 24.

148 "Egil's Saga," ch. 50.
} 
"welcomed them warmly and felt that their support would strengthen his forces greatly. In the course of their conversations he invited them to stay with him, enter his service, and defend his country. It was agreed that they would become King Athelstan's men."

In the course of fighting, Thorolf died. Egil later received two chests of silver, three gold arm rings, and an expensive cloak as his payment for fighting, compensation for his brother's death, and reward for poetry he composed.

In his second journey to England, Egil, after squirming his way out of a tricky situation with his old foe Eirik Bloodaxe, returned to see Athelstan who promptly offered him a merchant vessel full of wheat, honey, and other valuable goods if Egil would help defend his country and command his armies. ${ }^{149}$ Although the battle described in the story may actually be a fictionalized account of the battle of Brunnanburh, it is clear that the writers of the sagas were aware that their ancestors had previously fought for foreign kings for pay. The Anglo-Saxon Chronicle corroborates this evidence when in AD 937 it describes Aethelstan winning the battle of Brunnanburh with an alliance West Saxons, Mercians, and Danes. ${ }^{150}$

\footnotetext{
149 "Egil's Saga," ch. 63. Egils's actions provide an interesting commentary on the nature of service from a Scandinavian perspective. While the term "service" is used in more feudal lands to represent homage and duty, for Egil, it represented a bond which was terminated upon completion of assigned duties. It was employment. In this case, once Egil finished helping Aethelstan defend his land, he considered his work and obligation finished so he left. In ch. 55, Aethelstan said to Egil, "While it is your decision, of course, to leave here if you feel you have duties to attend to , Egil, I would prefer you to do otherwise; stay here permanently and accept anything you care to name." Egil declined. Aethelstan offered him a new contract upon their next meeting. Therefore, Egil's service was not perpetual unless stipulated. This concept may even possibly extend to Harald Klak and Rollo's situations as well. Although the Carolingians must have felt that the granting of a fiefs and the obligations that went with them (such as duty) would quell Viking rambunctiousness, Harald's continued rampages and Rollo's later incursions into Frankish territory indicates that the Norse felt otherwise.

${ }^{150}$ The Anglo Saxon Chronicle, trans. G.N. Garmonsway (New York: Dutton, 1965), year 937, version A.
} 
The Byzantine Empire

Probably the most prolific employer of Viking warriors, however, was the Byzantine Empire. In AD 912, a Byzantine envoy approached Oleg, prince of the Rus, in order to ratify the aforementioned treaty which the two had proposed the year before. ${ }^{151}$ Within it, the treaty outlined the inheritance rights for, "Russes professionally engaged in Greece under the orders of the Christian Emperor." Presumably, Vikings had been working for the Byzantine Empire for some time since the need had arisen to determine what happened to a dead Viking's possessions upon his death during military service with the Empire.

It is safe to assume then, that at some point between the time of the first literary evidence of contact between the Rus and the Byzantine Empire, AD 839 in the Annals of St. Bertin, and the time of the treaty that Vikings had begun to work in the Byzantine army. The Varangian guard, as it came be known, would earn such respect as to be granted the position of personal bodyguard to the Emperor. ${ }^{152}$ Comments in the sagas regarding men's entry into the guard indicate that it drew its members from primarily Scandinavian stock. In the "Saga of Grettir the Strong" it states, "They both asked to join the Varangian Guard and were welcomed when it was known that they were from Norway." ${ }^{153}$ Logan agrees with this finding. ${ }^{154}$

Later, upon renewing the treaty with Igor, Oleg's son, the Byzantine Empire would add the stipulation that,

${ }^{151}$ Russian Primary Chronicle, year 912.

${ }^{152}$ Magnus Magnusson and Hermann Palsson, King Harald's Saga: Harald Hardradi of Norway (NY: Penguin Books, 1966), 48.

153 "The Saga of Grettir the Strong," ch. 86.

${ }^{154}$ Logan, The Vikings in History, 196. 
"If our government shall desire of you military assistance for use against our adversaries, they shall communicate with your Great Prince, and he shall send us as many soldiers as we require. From this fact, other countries shall learn what amity the Greeks and the Russes entertain toward each other." 155

It is apparently to this stipulation that Basil II turned to in AD 989 when he faced internal revolt led by Bardas Phocas, the Emperor's chief rival. Prince Vladimir of the Rus sent six thousand armed troops to his aid. ${ }^{156}$ Many of the men left from this campaign stayed on with Basil and further swelled the ranks of the Varangian Guard.

Although many of the events are obviously exaggerated, "King Harald's Saga," presents a good example, or at least the most successful one, of the opportunity to win fame and fortune that was available down the rivers of the Rus. ${ }^{157}$ Fleeing for his life from Norway, Harald sailed to the court of King Jaroslav in Novgorod. Proving that opportunity existed even in this realm, Harald earned a commander's position within Jaroslav's forces. After enhancing his reputation as a leader and fighter in Russian territory, Harald traveled to Constantinople, immediately joined the Varangian Guard, and soon became their leader. Sigfus Blondal has surmised that although the basic rate of pay for Byzantine Imperial forces was from twelve to eighteen nomismata monthly, the probable pay of the Varangians once they had become a separate military unit was that of the Grand Hetairia, around forty numismata per month. ${ }^{158}$ In addition to this pay, soldiers received a portion of the booty. One sixth of all plundered wealth went to the

\footnotetext{
${ }^{155}$ Russian Primary Chronicle, year 945.

${ }^{156}$ For a detailed description of the numerous sources referring to this event, see Cross, The Russian Primary Chronicle, 245-246 (note 93, and Blondal, The Varangians of Byzantium, 43 (note 2).

${ }^{157}$ Snorri Sturluson, Heimskringla: King Harald's Saga, trans. Magnus Magnusson and Hermann Palsson (NY: Penguin Books, 1966).

${ }^{158}$ Sigfus Blondal, The Varangians of Byzantium (Cambridge: Cambridge University Press, 1978), 25-28.
} 
Emperor. The rest was split into two parts; one for the commanders, the other for the soldiers.

As the leader of the Varangians, Harald traveled throughout Italy and Asia Minor amassing a great wealth from plunder which he promptly sent back to Jaroslav to hold for him. The saga describes this amassed treasure twice after his return from Constantinople. In the first instance, it states that the hoard of wealth was so huge that no one in northern Europe had ever seen the like of it in one man's possession ever before. ${ }^{159}$ The second account occurs when Harald is sharing out his wealth to his nephew Magnus in response to being given equal control in the ruling of Norway. Yet again, all those present were amazed at the amount of wealth in one place at one time, but this time it also details a golden ingot the size of a man's head, weapons, golden bracelets, silver trimmed bowls laden with coins, and chests full of coins. ${ }^{160}$ Once again reiterating that these accounts are exaggerated, it is still obvious that saga transmits the message that men who worked in the Varangian Guard had the possibility to win fortune and fame for themselves. It is also equally important to note that work existed for men who were willing to fight. The "Saga of Grettir the Strong," states, "In those days many Norwegians went to Constantinople to serve as mercenaries."161

From all of these references it seems evident that one of the factors that drew Vikings abroad was the opportunity for work. That the work was of a violent and bloody nature is inconsequential. It is not their moral character that is under investigation, but their motivation for expansion. Some men were hired as the personal retinue of magnates, chieftains, and kings. Others were hired on a pay-by-plunder basis to swell the

\footnotetext{
${ }^{159}$ King Harald's Saga, ch. 16.

${ }^{160}$ King Harald's Saga, ch. 24.

161 "Saga of Grettir the Strong," ch. 85.
} 
ranks of ambitious rulers or Viking freebooters. Still more were specifically hired as mercenaries and paid up front so that they could be used as shock troops in internal politics. As Lund states, many Vikings acted as, "condottieri, taking service with a ruler who could be expected to pay well or to provide profitable opportunities for plunder."162 That these opportunities existed in Scandinavia, England, the Carolingian Empire, Russia, and the Byzantine Empire throughout the entirety of the Viking Age attests that this kind of work was in high demand. Thousands went abroad to foreign lands either seeking this work or participating in it. Therefore, raid viewed as employment is a plausible and substantial motivation for Viking expansion.

One thing to keep in mind regarding the previous arguments is that joining a merchant venture to ply one's wares or participating in a raid in order to gain wealth are two of the few means, if any others do exist, that would offer the "common" Scandinavian in the Viking age the prospect of a better station in life. As previously stated, there just weren't many avenues available during this time for people to make their lives easier, let alone any that were so potentially lucrative as raid or trade. The hundreds of shiploads of men who participated in this activity attest that they realized this as well. While these two methods made or broke kings and kingdoms, they were also the methods in which families and individuals could get their chance at something grander. By studying this system microscopically instead of macroscopically, we see that they are the techniques of men trying to earn a living in a difficult world.

\footnotetext{
$\overline{{ }^{162} \text { Lund, "Allies of God or Man," } 51 .}$
} 


\section{Chapter Two: Politics and Society}

Beyond the opportunity to better oneself by work, many other factors existed that heightened Viking expansion. For instance, the previous section investigated raid as a function of the individual and of individual gain, yet it refrained from studying the political and social motives behind those raids. There is a synergy between the two which perpetuates their relationship. However, there are other equally important political and social motives within Scandinavia that resulted in an increase of expansion during the Viking Age. The consolidation of power within Scandinavia, usually perpetrated by "join or die" tactic and in conjunction with religious conversion, had both political and social overtones. Furthermore, societal customs such as outlawry, polygamy, and inheritance rights compounded the number of Scandinavians who either chose or were forced to leave their homelands and start a new life abroad.

\section{Section One: Political Agendas}

The indelible mark left by the Vikings on Western Europe is that of consistent and perpetual raiding, so it is with this activity that a study on the political factors of Viking expansion must begin. One of the primary functions of raid is to enable external political conquest. This kind of expansion occurs when Scandinavian leaders invade lands abroad 
in order to increase their own political power. While this may seem very similar to the depiction of a "common" Viking participating in a raid to increase his position in society and create an easier life for himself, there is an important distinction between the two that requires separate study. Although the raid can earn for the ruler great wealth and fame, much as for the individual Viking, his actions are that of a "political entity" and therefore also affect the governance of the conquered area, all of the inhabitants within it, its law, taxes, tribute, and most importantly, its relations with other political entities. This type of raid is concerned with the making of kings and kingdoms. More specifically, there are three sub-headings under external raiding that are identifiable, each a separate political motive for expansion, that are relevant to this discussion.

The first involves raids conducted strictly in order to obtain power abroad. That power came from accumulating lands which would in return provide revenue from taxes, revenue from trade, and manpower for further conquest. These are acts of war and conquest designed to wrest political power from the hands of another and grasp it firmly to one's own bosom. The ultimate goal of conquest is to overcome completely, so it differs from the second political motive because forcibly occupying a territory results in only capricious acceptance and fickle tolerance and not supreme power. Attesting to this are the invasions of Russia, Ireland, and England.

Scandinavian rulers' attempts to insert themselves into the existing power structure of foreign countries concern the second sub-heading. Of the three, the second sub-heading is the most treacherous because of the duality inherent in studying the motives of a ruler. The political ambitions of a ruler reflect his personal ambitions and vice versa. As stated previously however, while personal gain does comment on the 
individual motives of the perpetrator, the political ramifications of their actions are far too important to ignore. Interestingly enough, the tactics used to obtain this result are reminiscent of actions of conquest, the first sub-heading. Many rulers would raid abroad and then, realizing that their opponent could not muster the strength to physically remove them, they would occupy an area thereby forcing the existing ruler to concede a portion of his land to the invader and welcome him into his service.

Last then, but by no means least, is raiding abroad for internal gain. These are raids perpetrated on foreign countries to finance internal revolutions within Scandinavia. Many would-be-kings organized and conducted raids outside of the bounds of Scandinavia in order to fund coups that would place them in power at home. Others used plundered wealth to sponsor attempts to consolidate neighboring territories under their own rule, thereby increasing the power of their kingdom.

\section{Conquest}

The first category, that of raiding in order to obtain political control and power, is easily the most recognizable throughout history. Although there is a lively debate endeavoring to establish the date of Scandinavian incursion into Russia, ${ }^{163}$ there can be no doubt as to the eventual purpose behind Viking expansion into this land. After recognizing the potential wealth that lay within its borders, primarily due to early and continued trade contact with the region, Rus princes conquered the warring tribes of the northern pre-Russian state. According to the Russian Primary Chronicle, after the Varangians had imposed themselves upon the tribes, the tribes rebelled and they were

\footnotetext{
${ }^{163}$ Thomas S. Noonan, "Why the Vikings First Came to Russia," Jahrbucher Fur Geschichte Osteuropas 34, no. 3 (1986): 321-348, provides a thorough explanation of these events.
} 
summarily driven out. ${ }^{164}$ However, realizing that they had no order without a strong leader, the tribes asked the Varangian Russes to come back to the land and govern them. These tribes, the Chuds, Slavs, Krivichians, and Ves, then choose the three brothers that were to come with all of their kinfolk to rule in three separate areas. The oldest of these, Rurik, outlived his siblings and peacefully assumed control of his brother's areas.

Realistically, the account gilds the process by depicting a peaceful transfer of power instead of what was more likely, which was a violent conquest. That the tribes "asked" a foreign group to take over and that they "chose" their rulers is a preposterous notion. It is probably more accurate to suppose that Rurik and his brothers realized that they could overcome the natives by force so they gathered a large group of men and did just that. ${ }^{165}$ After subduing the area, the brothers then brought the remainder of their relatives with them to settle. When Rurik's brothers died, he assumed control of all three territories. The rest of the story rings true enough so there is no reason to disbelieve it. A rebellion need not occur in his brother's provinces upon their deaths especially if Rurik's military presence was as strong as is implied by the mention of all of his kinsmen joining him as well as the continued payment of silver each year to the Varangians from various tribes in order to preserve the peace.

What follows is essentially a running commentary on how Oleg, who introduces himself as Rurik's son, but who the chronicle says was one of his kin, controlled the kingdom he inherited. From here, Oleg proceeds to subjugate other tribes in the area,

\footnotetext{
${ }^{164}$ Russian Primary Chronicle, beginning year 859.

${ }^{165}$ By stating that the tribes chose the Rus for their leaders, the chroniclers are either playing up the wisdom of the populace or playing down the maliciousness of the ancestors of the ruling family. Most likely, since the text was written circa 1116 AD for Prince Vladimir in Kiev, who was known to have a stalwart connection with Scandinavians, this portion of the chronicle was written to assert Vladimir's legitimacy based on his Scandinavian lineage. Either way the effect is the same; it masks the unpleasantness that marked the beginning of the Rus' reign. For more on the origin and authorship of the text see, Samuel Cross, Russian Primary Chronicle (Cambridge: The Medieval Academy of America, 1953), 3-50.
} 
thereby bringing them under his dominion. ${ }^{166}$ First, he destroyed his only potential Scandinavian rivals in Kiev. He then conquered the Derevlians, Severians, Polyanians, and the Radimichians while waging war on the Ulichians and the Tivercians. What is important to note here is that presumably by the use of force, Rurik had established a kingdom for himself in a foreign land, one that could then be passed down from generation to generation among his kin. Oleg then continued Rurik's legacy by overpowering further tribes and exerting his power over them. Although they would adopt more Slavic names and customs, Rurik's descendents ruled the northern river system of Russia until AD 1271.

It is presumable that since the aforementioned archaeological evidence indicates that mercantile activity took place sometime before military activity, trading contacts had originally brought back news about the wealth of this land. It is most likely that upon hearing this news, Rurik and his brothers subjugated it and laid the foundations for a Russian kingdom. Therefore, even though preliminary contact was mercantile, which by itself facilitated expansion, further designs upon this area came from a desire for political conquest and resulted in an increase in the size and speed of expansion.

This event was not an isolated instance, however. The most striking reminder to western eyes of Scandinavian political conquest occurred in England. The political climate in England was, at best, tumultuous. Various kingdoms were continually striving for dominance throughout the whole of the land. The lack of leadership and unity enticed freelance marauders to its shores. Although Viking fleets had begun harrying England in the late eighth century, it was not until AD 851 that they decided to over winter there. By 865 , the continuous raiding had caused enough disarray to allow a permanent force of

\footnotetext{
${ }^{166}$ Russian Primary Chronicle, years 880-885.
} 
occupation to eventually conquer all of England bar Wessex by AD 870. This marked the establishment of the Danelaw, a predominantly Scandinavian controlled territory whose boundary ran between the Thames to the Tees Rivers (from Watling Street in London to Scotland). However, this was a period of colonization for most. While individual invaders doled out whatever land they could take, a hodge podge of would-be kings, Scandinavian, English and Irish, vied for control of the various kingdoms within the Danelaw. One of the most memorable of these was Eirik Bloodaxe, a deposed king of Norway. There will be more on his exploits later. ${ }^{167}$ The period that followed the establishment of the Danelaw would also be troubled by a lack of unity, however this time it was on the part of the Vikings. As such, by AD 955 this explorative colonial venture ended with the native population absorbing the invaders and the re-conquest of the lands within the Danelaw by the descendents of Alfred, most notably Aethelstan. For the first time there was an English king ruling a unified England.

A period of relative peace ensued until AD 980 when a more organized Scandinavian state appeared due to Harald Bluetooth's restoration of Danish dominance over Norway. ${ }^{168}$ The next thirty-three years were a nightmare for the English King Aethelred, who repeatedly paid thousands of pounds of silver in Danegeld to the Viking invaders. The initial raids were small of scale, most likely freelance ventures, but they paved the way for other, more ambitious Viking leaders. The most significant of these leaders to English history was Harald's heir and Danish king, Svein Forkbeard.

Recognizing that England was ripe for the taking, Svein and Olaf Tryggvason, who later became the King of Norway, raided together in the early AD 990's. Although

\footnotetext{
${ }^{167}$ See pages, 85-87.

${ }^{168}$ Savage, The Anglo-Saxon Chronicle, 136.
} 
Olaf was eventually baptized and agreed never to raid in England again, he used the money he had coerced from the English over the years to his own good purpose. ${ }^{169}$ Svein, however, used his Danegeld to pay for the continued conquest of England. In AD 1002, Svein received twenty-four thousand pounds of silver in tribute on the condition that he would cease his evil deeds, but was back raiding in AD 1003 and 1004. In AD 1006, Svein returned for more plunder and in 1007 the English gave him thirty thousand pounds of silver to cease and desist his activity. His force returned again in AD 1010 and by 1012 they received forty-eight thousand pounds of silver. ${ }^{170}$ Based on this knowledge, it is most likely that on the promise of plunder and good pay, Svein organized a great fleet with which he could extort silver in tribute. After receiving an enormous sum to leave, Svein would pay his men their due and then use his share, which would have been considerable, to fund further raiding and begin the cycle anew. Magnusson also recognizes this cycle. ${ }^{171}$ As English morale plummeted, these raids bred such skepticism in Aethelred's abilities and such fear for the power of the invaders that in 1013, the people of England accepted Svein as their king.

It is obvious that Svein was interested in gaining wealth from his plundering expeditions. However, what is less obvious is the purpose for which he was exacting such exorbitant sums of silver. In perpetuating the cycle of plunder, by which he collected tribute to fund further military maneuvers, Svein reveals his true intentions, namely, that through continued military proceedings against a weakened and militarily

\footnotetext{
${ }^{169}$ See pages, 91-93.

${ }^{170}$ Although the Abingdon and Worcester Chronicles state this healthy sum, the Laud Chronicle claims that it was only eight thousand pounds of silver. However, seeing that over the past few years the sum had been rising, there is no reason to believe that Svein would have been bought off for so little a ransom in comparison.

${ }^{171}$ Magnusson, Viking Expansion Westward, 36.
} 
inferior enemy, he could bring the English under his control. If Svein was only interested in making a financial gain from his raids, he never would have accepted the title of king. In essence, by accepting the populace into his dominion he prevented further tribute of this kind. The tribute paid to Svein was an emergency tax levied against the threat of death, not a tax that a king regularly imposed upon his subjects. Granted, he would still earn revenues from the regular taxes he levied on his new subjects, but he would also be bothered with the expenses of governance and protection. His willingness to accept such responsibility demonstrates his desire for political power. As Reuter states, tribute, "served to create and reinforce political relationships, to determine military and hence political power."172

Unfortunately, Svein died the next year and although the fleet chose his son Cnut as king, the English silently sent word to Aethelred that they desired his return. They ousted Cnut by this trickery, but, borrowing a cue from his father, he extorted twenty-one thousand pounds of silver in tribute before he departed. Having earned enough money to finance a return trip in $\mathrm{AD} 1015$, Cnut won back the crown and reigned as the king of the English until his death in AD 1035. When Cnut's older brother Harald died in AD 1019, he also inherited Denmark and thus briefly untied the two countries.

Between the time of his father's and his brother's deaths, however, Cnut, like so many other Vikings of regal blood, had no territory of his own. Men sought out his patronage because his actions guaranteed them an attempt to go abroad and earn wealth, thereby bettering their own status. Laurence Larson stated, "As a landless prince Cnut had invaded England, had wrested large areas from the native line of kings, and now

\footnotetext{
${ }^{172}$ Reuter, "Plunder and Tribute," 87.
} 
possessed the entire kingdom." $" 173$ Cnut fulfilled his aspirations by conquering a foreign realm. Whereas Svein invaded seeking to enlarge his already sizeable kingdom, Cnut assaulted England in order to demand his inheritance, however weak of a claim that it was, and to dominate a kingdom of his very own. This, as well as the Russian example, shows that political conquest was a major factor in motivating Scandinavians to go overseas. Not only did these conquests bring royal designs upon foreign areas, but they also brought with them thousands of individuals who worked for the completion of those designs.

Not all conquest attempts were successful, however. In fact, many of them failed. Military defeat prevented some while conflicting reports obscure others. Indicative of this conflict is the career of Eirik Bloodaxe. Although king of Norway from AD 930936, Eirik was deposed for the cruel treatment of his subjects and for the murder of his brothers. ${ }^{174}$ For the next few years, Eirik disappeared from the written record. The sagas suppose that he was a rogue king, plundering throughout Scotland and England. He next made an appearance in the Anglo-Saxon Chronicle in AD 948 when due to his ravaging, the people of Northumbria accepted him as their king. ${ }^{175}$ Upon hearing of this defection, however, King Eadred ravaged Northumbria, forcing the Northumbrians to give up Eirik and pledge their allegiance to Eadred. Within a year, Northumbria had fallen to Olaf Cuaran, an Irish Viking, who was attempting to establish his control over the area. Eirik was not one to give up so easily, however, and in AD 952 he returned to York, ousted

\footnotetext{
${ }^{173}$ Laurence Larson, "The Political Policies of Cnut as King of England," The American Historical Review 15, no. 4 (Jul., 1910): 721.

${ }^{174}$ Sturluson, "The Saga of Harald Finehair," ch. 43.

175 The Anglo Saxon Chronicle, trans. G.N. Garmonsway (New York: Dutton, 1965), year 948, version A.
} 
Olaf, and claimed the kingdom of York for his own until 954. It is at this time that the Northumbrians drove Eirik out once again and he died in the ensuing battle.

All of this appears fairly straightforward, other than the rapidity of the events, based on the preceding argument of political conquest. Twice Eirik forcibly won the kingdom of York for himself. There is some difficulty in this interpretation however, because of conflicting reports in the sagas. According to the "Saga of Hakon the Good," Eirik fled the country with as many men as would follow him, went to Orkney to gather more men, and then went raiding in Scotland. ${ }^{176}$ Thus far, no inconsistencies arise. However, both the "Saga of Hakon the Good," and "Egil's Saga," report that the English King Aethelstan, upon hearing of Eirik's dethronement and armed approach, offered Eirik York to hold as his earl. ${ }^{177}$ This is believable not only because Aethelstan fostered Eirik's half brother Hakon at their father's request and was thus on good terms with the family, ${ }^{178}$ but also because Eirik was surely to have a sizeable force with him due to his royal lineage. If this was the case, then when Eirik gained the throne in AD 848 it wasn't by conquest, the first of the sub-headings of raid in this study. Instead, he would have contributed to the second sub-heading by having an existing power structure recognize his might and accept him as the Earl of Northumbria.

Unfortunately, Snorri's depiction cannot be correct because Aethelstan died in 940 and could therefore not have offered Eirik the earldom in AD 948. Although this seems to belie the earlier statement of the verisimilitude of the sagas, it does not, or at least not entirely. By the time that Snorri and the other writers of the sagas began to

\footnotetext{
${ }^{176}$ Snorri Sturluson, "The Saga of Hakon the Good," Heimskringla: History of the Kings of Norway, trans. Lee M. Hollander (Austin: University of Texas Press, 1964), ch. 3

177 Sturluson, "The Saga of Hakon the Good," ch. 3, and "Egil's Saga," ch. 60.

${ }^{178}$ Sturluson, "The Saga of Hakon the Good," ch. 1, and Sturluson, "The Saga of Harald Finehair, ch. 39.
} 
record the skaldic verses, the acceptance of Viking chieftains into existing Christian political hierarchies was commonplace. The writers knew that Aethelstan had hired foreign men to help defend his land and that there was great political turmoil within the Danelaw during this time. They knew that a strong connection linked Eirik and Aethelstan. They also knew that in many previous occasions, Christian leaders had granted titular positions to Viking invaders. All of the clues they had were accurate, but in attempting to surmise Eirik's fate during his twelve-year literary absence, their final leap of logic was incorrect. Eirik succeeded twice in conquering and subduing a realm of his very own, but the possibility of Viking leaders being asked to accept a political position within a foreign hierarchy was very real.

\section{Forcible Insertion}

While it has been shown previously that their erstwhile victims hired Vikings, this was done based on individual employment. Greater nobles hired lesser nobles who in turn hired "common" men. Another factor in Viking expansion based on raid exists, however, as touched upon above. This study must now investigate those Viking leaders who conducted raids in an attempt to insert themselves into an exiting political structure by use of force.

The Carolingian policy of conceding title and land to Viking rulers began in AD 826 when ex-Danish King Harald Klak, his wife, and many of his followers appeared at St Alban's in Mainz seeking refuge. Louis granted Harald the county of Rustringen from which he could mount attacks to try to regain his throne. For Louis, this was a very wise and calculated maneuver. By placing Harald in between the troublesome Danes, who had 
been causing him no small amount of difficulty, ${ }^{179}$ and the heart of his own lands, he created a defensive zone of protection against potential invaders. If Harald happened to succeed in his quests, the king of Denmark would be Louis' vassal.

In the following years, the political intrigue of Denmark and identity of those involved becomes quite difficult to say the least. However, it is during this time that Carolingians began granting political power and noble titles to those whom they could not beat back out of their realm. As mentioned earlier, in AD 841 the Annals of St. Bertin describe the grant of Walcheren and the surrounding regions to Harald, the nephew of Harald Klak, who had been raiding along the Frisian coast. ${ }^{180}$

Roric's ascension to power is much less complicated. In AD 850, he amassed a great army of men and ships and laid waste to territories along the Rhine and Waal rivers. ${ }^{181}$ The annals state that since Lothar could not remove him by force, Lothar received Roric into his service and granted him Dorestad and other counties to rule. Roric would hold this benefice until AD 867 when the local inhabitants threw him out. However, he would regain this land in an AD 870 treaty with Charles and receive Charles's further praise for a job well done in 872 .

Ten years later, another Viking would follow Roric's lead. After plundering Dorestad and the surrounding communities widely, the Viking Godafrid and his men sought refuge from an approaching army within a local fortification. Charles the Fat advanced upon them, but instead of fighting the Vikings, he granted Godafrid the lands

\footnotetext{
${ }^{179}$ See the "Royal Frankish Annals," years 809, 810, and the resulting years of political exile.

${ }^{180}$ In an interesting piece of detective work, Kenneth Cutler establishs that Harald Klak of Rustringen was not the Harald raiding in Frisia and that he had not been given Walcheren. This mysterious Harald was actually the nephew of Harald Klak of Rustringen and brother to Roric of Dorestad. He also states that Harald of Rustringen's brother, Hemming, was granted lands in western Frisia under similar terms. Whether he inherited these lands from their father or by force is still a matter of question, though. For more information see, http://php.iupui.edu/ kcutler/exiles.html, "The Case for Two Haralds."

${ }^{181}$ Annals of St. Bertin, year 850, and the Annals of Fulda, year 850.
} 
and duties previously held by Roric. ${ }^{182}$ Godafrid had succeeded in forcibly inserting himself into Charles's political hierarchy.

The evidence convincingly suggests that from AD 841 through 882 Carolingian rulers made a habit of allowing the leaders of Vikings who were too numerous, too strong, or too much of a bother, to coerce their way into important political positions. Not all attempts of this were fruitful for the invaders, however. Some attempts did fail. Janet Nelson notes that in AD 866, an unspecified group of Vikings seeking lands in Frisia unsuccessfully employed this tactic against Lothar. ${ }^{183}$ Even though all of the previous benefices granted to Vikings failed, each for a variety of reasons, Christian rulers were still willing to accept them into their ranks because they had no other choice at the time. Harald of Walcheren, Roric, and Godafrid all coerced the Carolingian Empire to give them benefices within the Empire's boundaries. Harald Klak was given Rustrigen in return for defending the land from future attacks and for mounting offensives against the encroaching Danish state.

However, the most notorious of these insertions is the aforementioned Rollo (Rolf) Ganger of Normandy. In AD 911, Charles the Simple halted the last significant raid by the Vikings in the Seine river valley. However, he was unable to dislodge them from the area and drive their presence from his lands, he struck a deal. By bringing Rollo into his service as count of Rouen, he effectively ended Viking raiding on the Seine, but more importantly from a modern perspective, he began a political dynasty whose descendants would conquer all of England in AD 1066. Although Rollo had entered into Charles's service, thereby making an employment arrangement, he had become

\footnotetext{
182 Annals of St. Bertin, year 882, and the Annals of Fulda, year 882.

${ }^{183}$ Janet L. Nelson, The Annals of St. Bertin, vol. 1 of Ninth Century Histories (NY: Manchester University Press, 1991), 132.
} 
responsible for the governance of Normandy, which was a political position of some responsibility. In this instance, Rollo knew that Charles did not have the resources to remove him. Therefore, by force of arms, Rollo acquired individual prestige and political power. Rollo's motives can be deemed political because he would have been aware that Christian rulers made such benefices to heathen marauders that were too powerful to be physically removed.

\section{Financing Internal Conflict}

This brings us to the final sub-heading of external raid as a motive for expansion. Raids of foreign countries often financed revolutions at home. In order to mount an offensive to take over or regain the throne, Viking leaders often went on raids in order to garner the funds, power, and prestige necessary to execute a coup. However, this area is exceedingly difficult to prove because the Vikings never left a balance sheet or receipt book that tells how plundered wealth and forced tribute was spent. Some generalizations can be made, though, in conjunction with the historical evidence that is available.

The first conflict in question concerns the rise to power of Harald Finehair. According to his saga in the Heimskringla, Harald inherited his father's kingdom, which at the time was only a few provinces, at the early age of 10 from his father Halfdan the Black. ${ }^{184}$ Although the date when Harald's began his reign as the sole leader of all of Norway is extremely difficult to determine, it is generally agreed upon that he consolidated the lesser kingdoms circa AD 880. Relative to this date is the increased level of raiding in England and Ireland beginning in the late AD 830's. It is during this time that both areas began to feel a massive influx of Viking invaders.

\footnotetext{
${ }^{184}$ Sturluson, “The Saga of Harald Finehair," ch. 1.
} 
By the mid ninth century, Vikings had founded Dublin in Ireland and were in control of a loosely organized Irish kingdom. Based on the artistic styles of archaeological finds, place names, and sword types, most scholars believe that the Irish raids were specifically of a Norwegian nature. ${ }^{185}$ As the tenth century approached, these finds increase drastically. In conjunction with this is the fact that the slave connection between Dublin and York, a predominately Norwegian area, had begun to thrive at this time. ${ }^{186}$ As Wamers indicates, "Westward expansion in Ireland funded Norwegian unification," 187 throughout the Viking Age.

The situation in England was no better. Although the raiding there had begun many years before, it was not until AD 851 that the attacks began in earnest based on the sharp increase in the number of ships landing on English shores. For England, the mid to late ninth century was a time of Viking raiding, conquest, and colonization with Scandinavian invaders establishing the Danelaw in the late AD 870's. By the time Harald had gained the throne, a system of plunder in England had already been long established and much of the wealth from those raids would have inevitably made it back to Norway.

The later career of Olaf Tryggvason also strongly suggests that raiding to gain funds for unification was indeed possible and probable. Harald's attempt to unify the

\footnotetext{
${ }^{185}$ See Egon Wamers, "Insular Finds in Viking Age Scandinavia and the State Formation of Norway,“ Ireland and Scandinavia in the Early Viking Age, (Blackrock: Four Courts Press, 1998), 49, Raghnall O'Floinn, "The Archaeology of the Early Viking Age in Ireland," Ireland and Scandinavia in the Early Viking Age, (Blackrock: Four Courts Press, 1998), 140, and Aidan Walsh, "A Summary Classification of Viking Age Swords in Ireland," Ireland and Scandinavia in the Early Viking Age, (Blackrock: Four Courts Press, 1998), 229 for support of this theme. Even though Sheehan, "Early Viking Age Silver Hoards,"186, and Ambrosiani, "Archaeological Response," 417, refute this idea, they do so only in stating that there was not a Norwegian dominance in raid on these areas. They feel that Denmark also played an important role in Ireland. Therefore, the above theory still holds true because all at least acknowledge a large Norwegian presence during this time.

${ }^{186}$ Clarke, Towns in the Viking Age, 93.

${ }^{187}$ Wamers, "Insular Finds," 72.
} 
Norway, which succeeded for a brief while, eventually failed and the region split into separate factions once again. Olaf, as well as many others, continually attempted to reunify the land albeit unsuccessfully until the waning of the Viking Age. According to his saga, Olaf spent four years (from AD 985-988) raiding in England, Cumberland, and Ireland. ${ }^{188}$ After taking a brief hiatus, Olaf returned to England in AD 991 with ninetythree ships. ${ }^{189}$ This is the first year that the English yielded tribute to the Vikings and it amounted to ten thousand pounds of silver. In AD 994, however, Olaf revisited England with Svein and extorted another sixteen thousand pounds.

At this point Aethelred effectively split his enemies by making a treaty with Olaf. He gave Olaf many "kingly gifts" in return for the Viking never returning to England in enmity. Previously, the Danish king, Harald Bluetooth, also Svein's father, had subjugated Norway. According to the "Saga of Olaf Tryggvason," Svein overthrew his father and became king of Denmark, but Norway accepted Hakon Sigurdson's rule. ${ }^{190}$ It is quite probable that Aethelred knew that if Olaf was given the opportunity to conquer Norway and bring the country back into Harald Finehair's bloodline, that he would do so. Since Svein still had some designs for Norway, indicated by the resultant turmoil from his men's various pledges to conquer it in the "Saga of Olaf Tryggvason,", 191 Olaf's potential war for the kingdom would be a tremendous headache for Svein. By helping Olaf, Aethelred was ridding himself of one invading force and creating a distraction for the other. Lund also suspects Aethelred of financially supporting Olaf's claim. ${ }^{192}$ In the very next year, Olaf journeyed to Norway and forced it to submit to his control.

\footnotetext{
${ }^{188}$ Sturluson, “The Saga of Olaf Tryggvason," chs. 29 and 30.

189 Anglo-Saxon Chronicle, year 991.

${ }^{190}$ Sturluson, "The Saga of Olaf Tryggvason," chs. 34-45.

${ }^{191}$ Sturluson, "The Saga of Olaf Tryggvason," ch. 35.

${ }^{192}$ Lund, "Allies of God or Man," 51.
} 
Therefore, Olaf's return and succession were made possible by the seasoning of his fighting force due to the raiding conducted in the years before his homecoming, by the incredible amounts of silver paid to him in tribute which he could use to further fund his cause, by the "kingly gifts" Aethelred used to buy his cessation of activity, and by the treaty that was ratified between himself and Aethelred.

It is apparent that using external raid to fund internal revolution occurred at least in Norway during the Viking Age. However, circumstances existed in Denmark during the early ninth century that lead one to believe that this tactic was perpetrated there as well. For instance, in AD 854 the Annals of Fulda states,

"The Northmen, who for twenty years continuously had cruelly afflicted with fire and slaughter and pillage those places on the borders of Francia which were accessible by ship, ..., returned to their own country. There a civil war had begun between Horic, king of the Danes, and Gudurm, his brother's son, who up till then had been driven by Horic from the country and had lived a piratical existence.",193

This passage indicates that Gudurm, after being expelled from the country for wanting to share in his uncle's power, lived as a pirate. There is little doubt that when he returned, Gudurm felt that he had the manpower necessary for victory. He had stolen enough wealth, attracted enough men, and earned enough power to support his designs on the throne.

In order to take over the throne at home, ambitious leaders had to have funding and resources. The main asset needed to support their coup was able-bodied men. Some men would join for a chance to remove the existing ruler if they felt he was inept or corrupt. Others would come due to previous ties or debt to the family conducting the coup. However, most of the men would be enticed on the premise of plunder, one of the

\footnotetext{
${ }^{193}$ Annals of Fulda, year 854.
} 
only ways available to men of this time to increase their wealth and station in life. Nearly all leaders would have to keep a retinue of some sort in employment, but the size of that retinue would depend on the existing wealth of the ruler and the loyalty of the men through difficult times. Anderson notes that in the eleventh century, Olaf the Saint's personal household provided for over one hundred and twenty fighting men not counting his family, thralls, and slaves. ${ }^{194}$ While this number appears rather large, Olaf was the King of Norway and could afford to maintain this force from his own private lands. For landless princes, dethroned monarchs, and ambitious petty kings, which many of the leaders of Viking raids were, ${ }^{195}$ large retinues could not have been maintained over long periods of time without giving them some recompense for their efforts. Continued raiding is the only way that large forces could be sustained and satiated without having a great deal of land to draw from in order to provide at least shelter, clothing, and food for them. Even so, while this retinue would be able to man a few ships, it would by no means be large enough to conquer a country.

The best way to attract men to your cause, to keep them from settling down, or prevent them from seeking employment elsewhere (as indicated by Prince Igor's predicament ${ }^{196}$ ), was to show them that you were a man worth fighting for, that you were successful in the endeavors of leaders. The most prominent and profitable endeavor undertaken by leaders was warfare. Olaf Trygvason fought for Prince Vladimir in Russia as the leader of his guards and participated in a long career of Viking activity before becoming king of Norway. ${ }^{197}$ It was their job to go to surrounding territories, plunder,

\footnotetext{
${ }^{194}$ Anderson, Expansion of Norway, 57.

195 Peter Sawyer, "Scandinavia in the Viking Age, 28.

${ }^{196}$ See earlier, 66-67.

197 Sturluson, "The Saga of Olaf Tryggvason," chs. 21, 29, and 30.
} 
then collect tribute. This is simply state sanctioned raiding. He also raided in and around the Baltic. Harald Hardrada also participated in Russian extortionism that eventually led him to be a mercenary captain in the Byzantine Empire. ${ }^{198}$ Olaf the Saint began his career as a Viking in England fighting with Thorkel the Tall among many other raiding exploits. ${ }^{199}$ Eirik Bloodaxe raided in the Baltic, Denmark, Frisia and Saxony before he commanded the attentions of men. ${ }^{200}$ All of these men achieved greatness in the eyes of others and attracted followers to their side because of their success at earning money through warfare.

The cycle as we have seen happened something like this. Armed with a personal retinue of warriors, ambitious rulers went on raids and brought back plenty of plundered wealth. Afterwards, they would reward their distinguished men with valuable trinkets that displayed both the wearer's worth (economically and socially), but also the ruler's generosity. People took notice of these deeds and rewards which slowly drew more people to the ruler's ranks. With this larger force, bigger raids were attempted, even more wealth was plundered, the leader's fame and proclivity for great hospitality grew greater still, as did the potential for others to make money and climb the social ladder from the leader's exploits, and his force continued to grow. As this cycle continues, more and more individuals participate which left a stronger and more continual presence of Norse expansion on foreign countries. However, as rulers brought more men under their sway, they had to be careful not to stop fighting. In a warrior aristocracy, if you stop fighting, the warriors will find another way to earn money, namely, by fighting for

\footnotetext{
${ }^{198}$ Sturluson, Harald Hardrada's Saga, ch. 2 and 3.

${ }^{199}$ Snorri Sturluson, "Saint Olaf's Saga," Heimskringla: The History of the Kings of Norway, trans. Lee M. Hollander (Austin: University of Texas Press, 1964), ch. 9.

${ }^{200}$ Sturluson, "The Saga of Harald Finehair," ch. 34.
} 
someone else. As is evidenced from the previous example of the Russian Prince Igor, personal loyalty can only go so far before armed men want some greater recompense for their time. ${ }^{201}$

A parallel can be drawn from Carolingian and Merovingian expansion. They continually raided neighboring territories in order to keep money in the king's treasury and to keep the fighting men of the land wealthy and happy. ${ }^{202}$ These raids also procured new lands for the king who could then use them to generate revenue or to entice powerful men into his service by granting them this land as a benefice. Although this is a rather jaded way to view the numerous rebellions occurring throughout their lands, both of these dynasties were involved in expanding their territory and extending their power. For instance, in AD 745 the Royal Frankish Annals note the irregularity that none of the rulers undertook a campaign that year. In fact, from AD 741 to 829 , a span of eightyeight years, only twenty-one years were spent in peace. Much of this time of conflict was spent trying to acquire Aquitaine and Saxony. A tax system had not yet evolved in their time, nor in the Vikings' time for that matter, that would allow kings to keep a standing army at the ready. Merovingian, Carolingian, and Scandinavian kings needed conflict in order to sustain themselves, let alone expand. If an opportunity didn't exist for a warrior to earn the proverbial brass ring, some other ruler could very easily come along and offer that warrior a bigger brass ring by participating in his personal war. In order to stay in power or procure more power, leaders needed to continually fight so that their men would have a reason to stay loyal to them. This is how many of the revolutions within the

\footnotetext{
${ }^{201}$ See previous, 66-67.

${ }^{202}$ For more on this see, Reuter, "Tribute and Plunder," 75-94.
} 
empire were started. ${ }^{203}$ This trend is easily visible by reading the Royal Frankish Annals, the Annals of St. Bertin, and the Annals of Fulda.

Returning to the Viking case, all of the men fighting for the leader would also need provisions. Although much of this material came from the plundered land during raiding, some stock was needed to protect against shortages and to supply the men to and from their destination. They would need to have foodstuffs like meat, grain, vegetables, and potable drinking supplies, especially alcohol. In addition, ships, ships' provisions like cordage, sails, oars, and sealant, along with weapons, armor, and clothing were also required to successfully complete the coup. If the leader didn't have any lands of his own to generate this kind of wealth, and, judging by the careers of Eirik Bloodaxe and Cnut Sveinson, not many of them did, they needed to find a way to generate it. Not everyone could do what Harald Klak did because not everyone had his connections or was willing to make his concessions. In his case, the Carolingian Empire had a marked interest in supporting his revolutions. ${ }^{204}$ For other would-be kings, however, where would the money come from? It would have to come from plundered wealth or from the promise of plundered wealth.

Therefore, by continued raiding, Viking leaders' reputations and wealth grew, attracting more men to their cause. This enabled them to either raid longer, raid larger targets, or to eventually conquer a land of their own or, depending on their goals, conquer their homeland. Without raiding to attract money and men, revolutions in the

\footnotetext{
${ }^{203}$ Specifically, the revolutions of Louis's sons Lothar, Pippin, and Louis. While these may have been succession disputes between the royal family, the vast number of men raised to fight for them from throughout Louis's kingdom, who had previously fought alongside the king, attests to the willingness of men to switch sides if the price was right.

${ }^{204}$ See earlier, 87-88.
} 
Scandinavian homelands would not have been so frequent or widespread. Most of the great Viking leaders only became great after they had fought for plunder.

\section{Consolidation of Power}

Ironically, although studying these chapters of Scandinavian history draws the argument of external raid being a major factor in Viking expansion to a close, it naturally provides an opportunity to discuss another factor that is important in expansion. While the previous examples tell greatly of how raids financed internal revolutions, they have yet to speak of the repercussions of said revolutions on the general populace within Norse homelands. Turning once again to Norway and the sagas, it is evident that power struggles between ruling factions within Scandinavia often forced many families to flee for their lives into the surrounding countries, thus further increasing expansion.

The first documented Scandinavian case of power consolidation causing an increase in the number of families searching for new homes abroad occurred when Harald Finehair united Norway under his sole rule. The first twenty chapters of the "Saga of Harald Finehair," deal explicitly with his eventual success at unifying the various petty kingdoms that peppered the Norwegian landscape. Chapter five of the saga relates that,

"And when he descended into the settled district, he had everyone killed and their houses burned down. But when the people learned of this, all who could, fled, some to Orka Dale, some to Gaular Dale, some into the forests. Some begged for mercy, and that was granted to all who came to the king and swore allegiance to him.",205

This articulates the style that most of the Viking kings exercised during consolidation attempts. It applies the old adage, "If they're not for me, they're against me." Would-be

${ }^{205}$ Sturluson, "The Saga of Harald Finehair," ch. 5. 
rulers gave the standing order that upon entering an inhabited area not under the king's control, everyone there should be killed except for those who were willing to swear allegiance to him. This excerpt testifies that the inhabitants in the path of consolidation frequently fled the region rather than oppose the tyranny they were facing by staying at home.

Often, as is specified above, these refugees escaped to nearby lands within the boundary of Scandinavia. For instance, the "Saga of Hakon the Good," states that a Ketil Jamte, his family, and many other migrants settled the region of Jamtaland on account of Harald's plans. ${ }^{206}$ However, what is also made clear is the extent to which the chroniclers give credit, or blame depending on the viewpoint, to Harald for causing mass migrations to non-Scandinavian countries. The most prominent of these is the colonization of Iceland. Supposedly, "During the times of warfare when King Harald brought Norway under his dominion, foreign lands such as the Faroes and Iceland were settled by Norwegians." ${ }^{207}$ It is quite apparent to scholars that Norwegians flocked to the island during this time based not only on archaeology, but also on the strong literary ties that connected Iceland and Norway. The first three chapters of the Laxdaela Saga, in which Ketil Flatnose's descendants decide to flee King Harald's wrath and settle in Iceland, supports this claim. ${ }^{208}$

Less remarked upon, however, is the effect that consolidation and succession disputes had on countries other than Iceland. For instance, Ketil Flatnose is reported to

\footnotetext{
${ }^{206}$ Sturluson, "The Saga of Hakon the Good," ch. 12.

207 Sturluson, "The Saga of Harald Finehair," ch. 19.

${ }^{208}$ Laxdaela Saga, trans. Margaret A. Arent (Seattle, University of Washington Press, 1964), ch. 1 through 3.
} 
have fled to Scotland in AD 890. ${ }^{209}$ Eirik Bloodaxe fled to York after his brother Hakon deposed him. ${ }^{210}$ These would not have been isolated incidents either. In AD 865 the Great Army invaded England and established the Danelaw. As has been previously mentioned, it is generally accepted that Harald's reign as king of Norway began circa AD 880. Although the Anglo-Saxon Chronicle records all of the deeds perpetrated by invaders after AD 865 through 903 as carried out by, "the host," the actual participants in the raids need not have been the same. In fact, it is quite probable that as the original raiders died or chose to settle down, reinforcements partially replenished their dwindling numbers. One of the sources for this replenishment could easily have been men who were fleeing Harald's oppression and seeking to start a new life elsewhere. Once settled, these men are likely to have sent for their families. In addition to this, it is inevitable that as merchants and raiders returned to Norway from England they would spread the news of who settled, who died, and of the availability of land. Therefore based on these reports, England would seem especially enticing when matters worsened in Norway to those whose extended family members had settled there or to those who sought to take advantage of the recently vacated land they had heard about.

It is evident then from the previous examples and arguments that the situation in Denmark was no better. After Hemming's death in AD 812, the two claimants to the throne, Sigifrid and Anulo, fought a great battle in which both died. ${ }^{211}$ Anulo's forces won the day however, and his two brothers became joint kings. One of these was the aforementioned Harald Klak. Within one year, the Danish nobles who had fled to Sweden due to the previous turmoil returned, ousted the brothers, and raised Horic to the

\footnotetext{
${ }^{209}$ Laxdaela Saga, ch. 4.

${ }^{210}$ Sturluson, "The Saga of Hakon the Good," ch. 3.

211 "Royal Frankish Annals," year 812.
} 
throne. As has previously been reported, Klak fled to Carolingia with his family and retainers. Not to be defeated, however, Klak returned to Denmark and in AD 819 he drove two of Horic's brothers from the land while forcing Horic to share the throne with him. The matter was by no means settled because Klak was once again driven from the country in AD 829 after many battles.

The rest of Horic's reign would not prove peaceful, however. He had driven his nephew Gudurm from the country and in AD 854 Gudurm returned with a large force. Showing that common folk as well as nobles had reason to flee during these civil wars, the Annals of Fulda states for this year that, "The two parties so wore each other down with killing that countless common people were killed, and of the royal family no one remained except one small boy." Within this brief and incomplete forty-two year span of history, many of Sigifrid's nobles, Harald Klak (twice), and Gudurm all sought refuge in foreign lands because of internal Danish power politics. This does not include the countless number of commoners or lesser nobles who feared for their lives and fled as well. It follows then that consolidation of power within Scandinavia forced many families and exiles to flee into surrounding foreign countries.

\section{Section Two: Societal Influences}

One of the most difficult aspects of writing history is being able to glean information from historical works which reflect unambiguously upon the social institutions of the whole society. Predominately, most written works were either created or funded by either the rich or religious, leaving little room in their pages to discuss the plight of the "common man." As White stated in regards to telling the complete history 
of mankind and not just that of the literate, "The peasant was the last to find his voice.,"212 Yet historians must actively search for this voice wherever it lay hidden or embedded and integrate it with those whose legacy was recorded so that we can have as accurate an understanding of the past as possible.

\section{Religion}

Throughout the Viking Age, the continual dispute over power within Scandinavian kingdoms forced noble and peasant alike to seek safety elsewhere. It is important to note that another similar, but social force often acted in tandem with political consolidation to cause yet further migration in the waning years of Viking activity. That force was religion. It is difficult to determine the magnitude of effect that religion had in terms of expansion, however, because in Scandinavia conversion came alongside political consolidation and both were accomplished by the sword. The similarity between the two and their inter-relationship warrants some discussion.

The most prominent examples of religious and political conversion occurring hand in hand are with Olaf Tryggvason and Olaf Haraldson, both kings of Norway. When Tryggvason came to Norway just before the turn of the tenth century, it is obvious that while he was maneuvering for political control of the country he was also attempting to Christianize it as well. The first leader he came in conflict with was Earl Sigurd, the ruler of islands just off the coast of Norway. His saga states,

"And when the earl came it was not long before the king commanded him to accept baptism, together with all his people, or else suffer death at once; and the king said he would devastate the islands with fire and flame, and lay the land waste unless the people accepted baptism." 213

\footnotetext{
${ }^{212}$ White, Medieval Technology, v.

213 Sturluson, "The Saga of Olaf Tryggvason," ch. 47.
} 
This passage makes Tryggvason's dual purpose clear. Not only was he planning on imposing his rule over Norway, he was also planning on imposing Christianity over it.

What is especially important about his actions are the ways in which he accomplished his tasks. Tryggvason's ancestor Harald Finehair had once united Norway by using join or die tactics. ${ }^{214}$ This caused great numbers of individuals and families to flee. Tryggvason's tactics were much the same. The statement that, "...all who dwelled in the eastern part of Vik were baptized, whereupon the king proceeded north in Vik and commanded all to accept Christianity; but those who spoke against it he punished severely, killing some, maiming others or driving them out of the country. As a result, ...during the summer and the following winter everyone in Vik was baptized," $215^{\circ}$

indicates that because of Tryggvason's religious demands the populace of Norway was forced to either submit, die, or flee.

The conversion didn't take beyond the main population centers, however. After Tryggvason's death in AD 1000, his relative Olaf Haraldson continued his work in the more rural climes of Norway. Although much of the country was relatively easy to bring in line, at least compared to previous succession attempts, Haraldson still had to concern himself with the acceptance of his reign and the Christianization of the populace. In "Saint Olaf's Saga," it states,

"He investigated how Christianity was being kept, and when he considered that there was need of improvement, he taught them the right faith. And he laid such stress on it that if he found anyone who did not want to abandon heathendom, he drove him out of the land. Some he had maimed, having their hands or feet lopped off or their eyes gouged out, others he had hanged or beheaded, but left no one unchastised who refused to serve God. And thus he proceeded in all that district." 216

\footnotetext{
${ }^{214}$ See the previous, 98-99

215 Sturluson, "The Saga of Olaf Tryggvason," ch. 53.

${ }^{216}$ Sturluson, "Saint Olaf's Saga," ch. 73.
} 
His efforts, which were the same used by his forebears to consolidate their throne, would earn him the eponym St. Olaf.

Although forced conversion did indeed act as a motive for expansion, its effects are obscured because in all of its recorded instances it occurs as a subsidiary of political consolidation. In addition to this, it was not until the twilight of the Viking Age that religious conversion became a significant factor of expansion within Scandinavia. Therefore, while religious conversion by the sword did factor into expansion, its total effect should be kept to a minimum due to the political agenda facilitating it and the lateness of its arrival.

\section{Outlawry and Necessity}

Bound within this discussion of consolidation is the concept of the outlaw. Up until this point, this discussion has deliberately avoided the use of the term outlaw because of the duality inherent in its defining characteristics. In attempting to exert or maintain their authority, many kings forced powerful men, such as the ones referred to above, to leave their homelands. This effectively banished them from the king's territory and made them political outlaws. Another form of outlaw existed, however. Social outlaws were banished from certain territories because of their unlawful acts within the bounds of society, not because they posed a threat to the ruler's sovereignty. The idea of the politically created outlaw must be separated from the socially created one because they are born from distinctly different circumstances and they produced distinctly different results. 
That is not to say that the conduct of political and social outlaws once they were banished could not be one in the same. For instance, Harald Finehair declared Rollo Ganger an outlaw for marauding through out the kingdom of Norway. ${ }^{217}$ This effectively meant that any man could kill Rollo without fear of retaliation from his kinsmen. Also, Rollo's kinsmen could not seek any monetary compensation, known as wergild or manprice, from his slayer for Rollo's death. Since Rollo had no home to return to and was a Viking captain, he proceeded to make the best of the situation and insert himself into the Carolingian power structure as previously related. ${ }^{218}$ Once outlawed his reaction was that of many other ambitious Vikings.

Although it is difficult to tell the severity of effect that outlaws had on expansion due to the paucity of source material on the subject, simple logic suggests that if a man was condemned to death in one country and had the means to leave it, then he would, especially since anyone could kill him without retribution. One assumes that this legal sentence motivated some of the colonial ventures, especially to Iceland, where relatively free land was available, and to England, where land was available to men willing to procure it by force. Social outlaws must be included in this discussion, however, because of the extraordinary accomplishments of Eirik the Red and his son Leif.

Outlawed in Norway for committing an unlawful murder, Eirik fled to Iceland with his family to start a new life. ${ }^{219}$ This instance supports the argument that social outlaws partially colonized Iceland. It seems, however, that Eirik did not learn his lesson

\footnotetext{
${ }^{217}$ Sturluson, "The Saga of Harald Finehair," ch. 24.

218 See earlier, 71, 89-90.

219 "Eirik the Red's Saga," The Complete Sagas of Icelanders, Vol. 1 (Reykjavik: Leifur Eiriksson Publishing, 1997), ch. 2.
} 
because within a few years of arriving Eirik again murdered someone and was outlawed to islands off the coast of Iceland. Within a few years, Eirik murdered another man.

Once again, the Icelanders declared him an outlaw this time forcing Eirik to flee from the area entirely.

Realizing that his options were somewhat limited, since the colonization of English land had long since subsided and he was effectively banned from living in Norway and Iceland, Eirik turned abroad into the unknown. During his stay in Iceland, he had learned that a man by the name of Gunnbjorn had once sighted an uninhabited land to the west of Iceland some years previous. Seizing this opportunity, Eirik packed up his family circa AD 983 and headed out into the unknown searching for this new land. He returned to Iceland in AD 986 and persuaded twenty-five shiploads of men and women to help him start the first settlement in Greenland, his name for this newly discovered piece of the world. Attesting to the difficulties of North Atlantic travel, only fourteen of the ships successfully completed the journey.

Soon after this (c. AD 1000), Eirik's son Leif would search for and find America. Leif's motives for seeking out this new land are very difficult to ascertain, due largely to the lack of detail regarding it in the sagas, but some assumptions can be made. "The Saga of the Greenlanders," states that when Bjarni Herjolfsson, the son of one of Eirik's crewmen, attempted to sail to Greenland he was blown off course. ${ }^{220}$ He and his men sighted wooded land, but, against the wishes of his crew to stop and seek provisions, Bjarni refused to put to shore because he felt that it wasn't Greenland.

\footnotetext{
220 “The Saga of the Greenlanders," The Complete Sagas of Icelanders, Vol. 1 (Reykjavik: Leifur Eiriksson Publishing, 1997), ch. 2.
} 
Upon finally reaching Greenland, Bjarni was much criticized for not exploring this discovery. The Greenlanders were very curious about new lands to the west. Why? Certainly they were not experiencing any population pressure since they had just begun to settle Greenland only a few years before. There is no mention of any conflict that might cause others to want to leave. The only piece of news that Bjarni brought back with him was that forests covered much of the land they sailed past.

Thomas McGovern has shown that, "Early colonists seem to have been remarkable flexible and resilient, swiftly altering a generalized herding/fishing/hunting economy to fit local resources and environmental constraints." ${ }^{221}$ One of those constraints was the lack of wood. Greenland is a country that has always been very sparsely populated by trees. The thought of a nearby land overflowing with trees would have been very enticing to Greenland's population because wood was a very valuable commodity due to its absence. Wood was a natural resource that made survival easier because of its many uses in homes, ships, cooking, blacksmithing, fuel, etc... The Greenlanders had identified a potentially vast supply of a natural resource that would ease their subsistence living. Whoever succeeded in bringing back this resource would not only make his life easier, but he would also become wealthy by providing it for others. $^{222}$ Therefore, Leif's efforts in reaching the new world were based on a societal need to ease their way of life and the opportunity to increase one's social status in the process.

\footnotetext{
${ }^{221}$ Thomas H. McGovern, The Archaeology of the Norse North Atlantic. Annual Review of Anthropology 19 (1990): 333.

${ }^{222}$ For evidence that wealth and respect would follow the exploitation of this resource (and others found in the new world), see "The Greenlander's Saga," ch. 3 and 4.
} 
Had Eirik not have been declared an outlaw, there is a good possibility that Greenland, and America for that matter, would never have been discovered by the Vikings. It seems ironic that these incredible moments in European and American history should be born from the repercussions of multiple illegal acts.

\section{Polygamy and Inheritance}

Outlawry was not the only social motive for expansion, however, but it does provide a serviceable bridge between political and social motives. Other important social factors helped to increase the number of men venturing abroad during the Viking Age. As briefly discussed in the introduction, ${ }^{223}$ polygamy and inheritance rights helped fuel the longships with men as they sailed overseas, carrying with them a desire for wealth, power, land, freedom, and choice.

One of the best examples of this was the mighty Harald Finehair himself. The poet Hornklofi relates a portion of Harald's wedded history when he composed the following verse about Harald's betrothal to Ragnhild, daughter of King Eirik of Jutland, who bore Eirik Bloodaxe:

$$
\begin{aligned}
& \text { "The high-born liege-lord } \\
& \text { chose the lady from Denmark, } \\
& \text { broke with his Rogaland loves } \\
& \text { and his lemans (rulers) of Horthaland, } \\
& \text { the maidens of Halogaland } \\
& \text { and of Hathaland eke."224 }
\end{aligned}
$$

The poem basically states that although Harald had many previous and current wives, which number up to eleven in a later verse, he chose another, Ragnhild from Denmark, as his favorite and let the others go. Two of the eleven are known from this saga. Asa,

\footnotetext{
${ }^{223}$ See introduction, 7-9.

${ }^{224}$ Sturluson, "The Saga of Harald Finehair," ch. 21.
} 
daughter of Earl Hakon Grjotgardson, bore Harald four sons. They were Guthorm, Halfdan the Black (named after Harald's father), Halfdan the White, and Sigfrod. ${ }^{225}$ The other was named Gyda (who was from Hordaland) and she bore Alof , a daughter, and four sons, Hrorek, Sigtrygg, Frodi, and Thorgils. ${ }^{226}$

After Ragnhild, however, Harald continued to wed and sire children. Olaf, Bjorn, and Ragnar were born from Svanhild. ${ }^{227}$ With Ashild he fathered Dag, Hring, Gudrod (a girl), and Ingigerd (a girl). ${ }^{228}$ After her came Snaefrid and their children Sigurd, Halfdan, Gudrod (a girl), and Ragnvald. ${ }^{229}$ The last woman with whom Harald is said to have produced children with was Thora, one of his servant girls, when he was at the age of seventy. From this union, Hakon the Good was born. ${ }^{230}$ This account, incomplete as it is, yields that Harald fathered eighteen sons and four daughters.

Needless to say, with this number of heirs to the throne problems were sure to arise. By the time he was fifty, many of Harald's sons were grown men although some had died from various causes. In an attempt to stop them bullying his earls and the people who swore allegiance to those earls, Harald gave each of his surviving sons control of one of his districts, the title king, and half of the revenues that the district generated. $^{231}$ However, Harald gave his son Eirik Bloodaxe three districts to rule and designated Eirik as his heir. Feeling that their portions were too small, Frode and Thorgils asked for ships of war demanding the opportunity to increase their holdings.

\footnotetext{
${ }^{225}$ Ibid., ch. 17.

${ }^{226}$ Ibid., ch. 20.

${ }^{227}$ Ibid., ch. 21

${ }^{228}$ Ibid., ch. 21.

${ }^{229}$ Ibid., ch. 25.

${ }^{230}$ Ibid., ch. 37.

${ }^{231}$ Ibid., ch. 33 .
} 
Harald conceded these demands and these sons plundered in Ireland, Scotland, and England.

In the next few years of Harald's reign, he elevated Eirik, his favorite son, to the throne. He lived only three more years. Although Harald intended only one of his son's to rule after his death, Eirik was not the first son. Therefore, primogeniture was not in effect. The king could chose who would succeed him, though, so similar rights of inheritance would have applied. That did not mean that other potential candidates for the throne would necessarily heed the dying king's decree. Eirik's power never lasted. Greedy for the crown, some of Eirik's half-brothers assumed total control of their districts and plotted against him. This made Eirik furious so he killed them and severely punished those who followed them. In the end, his brutality resulted in Hakon the Good's return to Norway (he had been fostered in Aethelstan's court) and seizure of the crown.

This outline suggests that one of the reasons there were so many struggles for the crown within Scandinavia, why it continually had to be re-consolidated under one leader's rule, is that as long as a contender had royal blood, he was a viable candidate for the kingship. While polygamy may or may not have been the norm for common folk, the sagas indicate that these kind of inheritance disputes also existed within less noble circles. Even though outlawed in Norway, Egil Skallagrimson returned to the land in order to sue for his wife's inheritance. In this instance, the claimants to the land were Asgerd, Egil's wife born from an unlawful union (unlawful only because Asgerd's family disapproved of the wedding), and Gunnhild, a daughter from a lawful wedding. In order to make his case stronger, Onund, Gunnhild's husband, stated that since Asgerd had the 
status of a slave woman because she was born under the king's outlawry by the unlawful union, she was unable to claim any inheritance. In addition, Onund infomrred Egil that his case could not stand because the judges in the case, King Eirik Bloodaxe and Queen Gunnhild, had declared that, "every case of mine (Onund's) in their realm will be ruled in my favor." 232

This episode tells greatly of the rights of women in Scandinavia. Women were entitled to inherit land as long as they were not slaves, but they could not argue for themselves in court and the land would ultimately become her husband's possession. However, this episode tells even more about the difficulties inherent in Scandinavian inheritance laws. With no clear rights of succession, a large number of offspring who fit the requirements provided by multiple marriages, and collusion from influential parties, conflict was inevitable. Succession and inheritance disputes also developed between offspring in the Christian world, as with the sons of Louis, but the church provided an acceptable substitution for fratricide. Instead of killing your brother or other family members, they could live out the rest of their lives in a monastery. In Scandinavia, no such institution existed, so the only recourse for weaker or defeated rivals who still wished to rule was either death or foreign adventure. As is evident, many chose to carve out a better life for themselves abroad.

Many of these rules would also apply to the "common" Scandinavian as well. While the division of lands or labor between family members might keep some of the potential inheritors of familial farms from seeking their own lands abroad, the Vikings were not well known for sharing. Owning land not only increased one's social status, but it also provided its owner with the ability to survive. Land, if properly worked, yielded

232 "Egil's Saga," ch. 57. 
food and other materials for continued existence. The desire to provide basic subsistence for one's own well being as well as one's family would definitely have a hand in increasing a man's willingness to seek land abroad if the opportunity existed.

\section{Norms and Expectations}

In addition to inheritance customs, there were certain societal expectations that not only created expansion, but they also assisted in its perpetuation. One of these societal norms was a man's desire to increase his social status. Social status was of great importance to the Vikings. ${ }^{233}$ For instance, Grjotgard, the brother of Earl Sigurd, held no title of honor, possessed little land, and for this people respected him little. ${ }^{234}$ In order to compensate for these shortcomings, he gathered a few men around him and spent his summers gathering wealth and property by raiding. In addition, he participated in a plot to murder his brother so that he might win the earldom for himself. Owning land, in this society as well as others, was the key to power, success, prestige, and an easier means of living. Based on the sheer volume of accounts when Vikings murdered their fathers, brothers, or other kin, unless we are willing to accept that excessive jealousy and greed were natural traits of all Scandinavians, Grjotgard's actions were efforts to climb the social ladder. By doing these things, which gained him wealth, power, and prestige, he

\footnotetext{
${ }^{233}$ Potential reasons for this are threefold: social, economic, and legal freedom. Most assuredly, people of a higher status had an easier and wealthier life. Peasants could hardly expect other people to just give them supplies and money. Kings and earls often had this in addition to serving attendants and multiple slaves. Those with a higher social status, especially those of royal blood, would find it easier to attract followers to their cause if others held them in high esteem. More followers meant that a greater variety of economic outlets were available from trading or raiding on small towns, to raiding major economic centers. Consequently, this increased wealth and power which increased social status. Lastly, the Scandinavian legal system was based on oath-takers. Men needed a certain number of men to take oaths on their behalf in order to succeed in legal matters. The higher a persons social status, the greater the chances of finding people willing to take an oath.

${ }^{234}$ Snorri Sturluson, "The Saga of Harald Graycloak," Heimskringla: History of the Kings of Norway, trans. Lee M. Hollander (Austin: University of Texas Press, 1964), ch. 4.
} 
could expect to be held in higher esteem. Once someone accomplished something great, that person could anticipate social respect.

This desire for greatness in society is evident in other instances as well. Thinking herself too good to marry anyone other than the ruler of an entire country, Gyda stipulated that she would not wed Harald Finehair until he united all of Norway under his rule. $^{235}$ Although the sagas provide an overly simplistic explanation, Harald conquered all of Norway in order to impress a girl. She would only wed a man great enough to accomplish the daunting task of uniting the warring kingdoms.

Gold Harald asked his brother Harald Bluetooth, the king of Denmark, if he would split Denmark with him. ${ }^{236}$ Bluetooth declined. When Gold Harald asked his friend Earl Hakon of Norway whether he should forget the matter or forcefully take the throne from his brother, Hakon replied,

"Consider with yourself how much you might be able to accomplish. To execute such dangerous undertakings requires that a man be bold and undaunted and not hesitate to use fair means or foul, so that he may accomplish what he has set out to do. But it is risky to embark on a great enterprise and then to abandon it abjectly.,"237

Hakon's statements imply that people will lose respect in Gold Harald if he decided to begin a war and was not man enough to see it through until the end. In Samuel Laing's translation of this passage, Hakon states to Harald, "to take up great resolutions, and then to lay them aside, would only end in dishonor," implying further still that Harald's concern should be for his honor. ${ }^{238}$ Hakon's argument centered not around whether the

\footnotetext{
235 Sturluson, "The Saga of Harald Finehair," ch. 3.

${ }^{236}$ Sturluson, "The Saga of Olaf Tryggvason," ch. 9.

${ }^{237}$ Sturluson, "The Saga of Olaf Trygvason," ch. 10.

${ }^{238}$ Snorri Sturluson, "King Olaf Trygvason's Saga," trans, Samuel Laing, May 1996, http://sunsite.berkeley.edu/OMACL/Heimskringla/, (18 April 2002).
} 
kingdom was rightfully Harald's nor whether it was right to attack his brother, but whether or not he was willing to put his honor, i.e. his social standing, on the line.

Keeping in mind then how important it was to increase social status, how could men find opportunities to do so? As previously stated, the only means in which men could count on substantial gains was by trading or raiding. Very few farmers strike it rich. Not everyone was wealthy enough to own a ship to transport either goods or armed men across the sea. Reuter has stated that often in Carolingian times, men viewed kings as the provider of these opportunities. ${ }^{239}$

This also translates to Scandinavia. For instance, the previous account of how Igor's retinue goaded him into attacking a neighboring tribe indicates that these men expected their lord to provide them the opportunity to gain material wealth. Harald Finehair supplied his unruly sons with ships of war when his endowment of land to them did not live up to their standards. By the time of Harald Grafeld (c. AD 960), the king's raids were an annual and anticipated event. ${ }^{240}$

However, in Viking terms, this expectation to bestow opportunity also applied to fathers who possessed the means to do so for their sons and not just to kings. By comparing the actions of Skallagrim and Brynjolf, ${ }^{241}$ it appears that a father's duty in the Viking age required him to provide his sons some means of self-improvement.

Skallagrim chose to equip his sons with ships of war. Brynjolf, on the other hand, gave his son a trading vessel.

Lastly, a brief nod must be paid to family induced migrations. Familial migration is expansion that occurs when a man, for it was generally the men at this time

\footnotetext{
${ }^{239}$ Reuter, "Plunder and Tribute," 79.

${ }^{240}$ Sturluson, "The Saga of Harald Graycloak," ch. 9.

${ }^{241}$ See, 67 and 56 respectively.
} 
who participated in expansionist events, settled in a new area as a result of the aforementioned causes and then sent for his family to join him. In Russia, Roric sent for all of his kin to join him after he had claimed rule in Russia. The availability of land in Iceland enticed Ketil Flatnose's descendants to take their families and populate Iceland. Harlald Klak brought all of his family and his personal retainers with him to Carolingia when his rivals removed him from the throne. Although we have no means of judging the volume of traffic that took advantage of this addendum to expansion, their numbers cannot be ignored.

Societal change is usually excruciatingly slow and these societal norms would die hard. One of the signs of a good ruler was that he was generous and provided for constituents. In addition, raiding was a traditional means of making or supplementing an income during the Viking Age. People's fathers and grandfathers had made their fame and fortune by doing so, why shouldn't they? These customs would help to perpetuate Viking activity abroad, thereby continuing the phenomenon of expansion. Eventually, however, the structure and patterns of society would change enough so that these expectations nearly cease to exist. 


\section{Chapter Three: Analysis of Expansion}

Until now, Norse scholarship has lacked a detailed investigation of the myriad of catalysts involved in propelling Scandinavians abroad from the eighth through the eleventh centuries. Scholars have cited population pressure and a search for wealth as the primary causes of this curious phenomenon, but these explanations failed to encompass both the enormity of the migrations as well as individual motives behind such general classifications. There was much more at work in these northern homelands than simply a blossoming population and greed.

Although the Vikings will always be remembered for the violent impact that they had on Western Europe and beyond, many factors of expansion dwell within the rather peaceful side of their society. For instance, Scandinavian participation in mercantile ventures before the Viking Age and their continued interest in them throughout the period indicate that the peaceful manufacture and sale of goods was a significant aspect in expansion. In addition, as the victims of internal violence brought about by political infighting and consolidation, many Scandinavians fled their homelands in search of peace and prosperity. Necessity and legal custom such as outlawry would also force many to explore the surrounding world. 
While the peaceful side of Viking expansion must not be forgotten, equally indelible was the violence with which they entered into the lives and chronicles of Christian writers. There can be no mistaking that many of the raids were simply piratical in nature. However, just as many were conducted for political and social gain. Whether to conquer a foreign land or to forcibly gain entrance into its political hierarchy, the Vikings were willing to go to great and devastating lengths to achieve power, fame, and a higher social status among their people. Known throughout Christendom for their willingness to die in combat and their ferocity on the battlefield, Viking men were sought after by Norse and Christian rulers alike for their high caliber as mercenaries.

However, these factors rarely occurred in isolation. These motives were consistently bound up with one another which is one of the reasons why Scandinavian expansion was so sudden, volatile, and long lasting. Having identified the motives involved in Viking expansion, though, is the first step in obtaining a greater understanding of specific events in history. Take, for instance, the conquest and establishment of the Danelaw. This next section will apply the previously argued model for motives of Scandinavian expansion in England during the mid to late ninth century. In order to determine the sheer volume of expansion within this time period and within these lands, the literary record will be searched for instances that tell the numbers of men who participated in these ventures.

Although the earliest raids in England occurred in the very late eighth century, the Vikings had been trading with the English from decades before. This violence marked a change in how the Norse interacted with their neighbors. Once the initial raiding began, a period of relative quiet followed on the Scandinavian front. However, this changed in 
AD 835 when a large ship force of men ravaged Sheppey. Although we have no means of telling how accurate they are, the references in the Anglo-Saxon Chronicle are the only way we have of judging the size of the invading forces. However, since the monks recorded these numbers, the proceeding explanation of events can also yield a rough estimate for the number of Scandinavians who invaded England in order to assist in the establishment of the Danelaw. ${ }^{242}$ These troops are accountable for the conquest of the majority of England and the installation of a variety of Vikings rulers throughout the land. It is important to note that there is some likelihood that men would take part in more than one voyage. This is an inevitable difficulty in calculations of this type. However, this overlap in numbers can be kept to a minimum when realizing that many men would die on such missions, thereby preventing them from making a second trip, others would have grown too old or too injured to participate in successive voyages, and still others would look to settle down at home with their newly won wealth or colonize the new land that they helped conquer. With that caveat stated, the calculations can begin.

The raiding from AD 835 through 850 was strictly piratical. There is no reliable evidence suggesting that these raids were anything more than summer smash-and-grab affairs designed to earn its participants a quick profit. The forces neither stayed the winter, nor did they attempt to conquer an area or insert themselves into the English power structure. For many individual Vikings, these raids were mercenary work that not

\footnotetext{
${ }^{242}$ The proceeding figures are based on accounts recorded in the Parker Chronicle. This single portion of the chronicle is used because it is the oldest manuscript and therefore has less of a chance for continued scribal error through recopying. In addition, its figures are congruent with that of many of the other chronicles and translations. For instance, for the year AD 840, the Parker and the Laud Chronicle both relate that thirty-three ships' companies fought at Southampton. However, the translation by Anne Savage records their number as thirty-seven.
} 
only provided pay, but also gave them the opportunity to quickly increase their status or simply improve their quality of living. The leaders of these bands were probably powerful social outlaws or political exiles who used plunder as a means either make a living or to increase their status so they could finance, man, and equip their return to Scandinavia.

The calculation for the numbers of men involved in these expeditions begins with a bit of a hiccup. In $\mathrm{AD} 835$, unspecified numbers of men ravaged Sheppey. Based on the lack of information given no accurate assessment of the size of this force can be made. Therefore, their tally will be reduced to one ship load of men, which would be the minimum required, in order to offset any unintentional overestimation of the quantity of men involved in this entire endeavor. Thirty-five ship-companies attacked Carhampton in $\mathrm{AD} 836 .{ }^{243}$ In $\mathrm{AD} 838$, a "great pirate force" raided in Wessex, but King Ecgbryht put them to flight. Although there is no finite amount related here, we could infer by the use of the quantifier "great" that this raid probably contained more ships than the previous one because of the proximity of the references to one another. However, in order to guard against inflating the estimate, let us presume that they were equal. Thirty-three ships plundered Southampton in AD 840. Carhampton suffered the arrival of another thirty-five ships in AD 843. The size of the forces surrounding AD 838 suggests that the earlier estimate of thirty-five is within safe limits.

Some instances of raiding during this span have purposefully not been included for discussion up to this point. There are many times in the chronicle when there are absolutely no references made to the number of ships or men that participated in a raid. However, in order to be as thorough as possible, these attacks will be represented by one

\footnotetext{
${ }^{243}$ The Laud Chronicle states this number as twenty-five.
} 
shipload of men as with the previous example above. In order for there to be a raid, at least one ship would have had to turn up for it. The years of AD 840, 841, 842, 848, and 850 all contain references to separate raids against the English. Therefore, at the absolute least, five ships will be accounted for in this calculation. This yields the very conservative estimate that a grand total of one hundred forty three ships raided in England from AD 835 through 850 .

The next period of attacks assumes a different character. The undetermined number of heathen men who had been defeated in AD 850 at Wicgeanbeorg decided to spend the winter in England. From AD 851 through 876 the volume of Scandinavian men flooding into English lands increased dramatically. Many of these are still piratical ventures which, according to previous definitions, would constitute mercenary work for some and financial operations for others. However, it is evident from the Wicgeanbeorg fleet and the many others that followed their practice of spending the winter that the focus of the invasions had changed. By the end of this time span, Halfdan, the leader of the enlarged invading host, shared out the conquered territory in Northumbria and the invaders began to settle down, farm, and provide for themselves. This indicates that the initial raids revealed a weakness that the Scandinavians were willing to exploit. Because the English were incapable of resisting their incursions, due largely to a lack of unified resistance, Scandinavians seeking not only wealth, but also land now participated in the journey to England. Although there were many motives behind this desire for land, some of the most prominent factors behind these migrations were caused by the lack of inheritable land due to polygamy, conflict resulting from inheritance rights, flight from 
Scandinavia due to political infighting and the consolidation of power, and a desire to increase one's social status.

While these raids were partly colonialist in nature, they also masked attempts by Scandinavian rulers to acquire a kingdom of their own and are therefore also political in nature. By AD 870 the invading Vikings controlled and settled in all of England besides Wessex. Their forces then split, some continuing to raid, attesting to the desire of some to accumulate still more wealth, and the rest followed Halfdan north to Yorkshire. It is here that these men settled. Now, for the most part, these men didn't choose the pieces of land that they settled upon. The sheer fact that the chronicle reports that in AD 876 Halfdan shared out the land to them indicates that since he was in charge of the force, by default, he was also in charge of the land they conquered. Therefore, part of the men's reward in fighting for Halfdan, part of their pay, was that he granted them a parcel of land for their very own. By doing so, Halfdan established himself as the ruler in the kingdom of York. His motive was to become king. Unfortunately for him, however, his reign was rather brief because he died two years later in Wessex.

The motives of Halfdan's men are threefold. Firstly, these men were employed by Halfdan to fight for him so their fist motive was economical. Second, the conspicuous wealth and fame that they earned would also provide a form of social payment meaning that with this wealth they would be held in higher esteem. Lastly, that they were willing to accept udal land as payment indicates that these men also had a desire to settle in a new territory and were therefore colonial in nature.

Returning to the calculation then for this second phase of the Viking invasions, in AD 851 King Athelstan captured nine of the "great host" of ships that invaded Kent 
before he drove off the rest. We can infer from this that at least ten ships, but probably more, took part in this raid because although nine were captured, some escaped. Three hundred fifty shiploads of men also came to Wicgeanbeorg in AD 851. The English then "made the greatest slaughter of a heathen host," ever heard of to that time. It is therefore unlikely that either force would have over wintered in England after their defeat because they risked being utterly decimated.

Further raids of undefined number occur for the next few years. Since their numbers are not provided, the minimum of one must be used to approximate their size. In $\mathrm{AD} 853$, a heathen host was defeated near Thanet. Another force wintered in Sheppey for the first time in AD 855. A "great pirate host" stormed Winchester in 860, but they were defeated. It is significant to note that even though the AD 855 raiders had enough manpower to forcibly stay the winter and the size of the 860 raiders was counted as "great," there are no quantifiers in the immediate vicinity of the text which can be used to determine their approximate numbers, so they will also be counted as one.

Another "great host" of men, known today as the Great Army, ravaged throughout England in AD 865. That this force would eventually take over and settle throughout all of northern England attests to its sheer size. Based on this and the fact that the English routed an earlier force of three hundred and fifty ships, the Great Army must have been quite large indeed. There is, however, a later account depicting the loss of the Viking horde's ships. After their forces had split in the early AD 870's, some followed Halfdan during the formation of his Yorkish kingdom. The other force proceeded to Exeter where one hundred twenty of their ships were lost at sea. Although this was only a portion of the entire army, for the sake of argument, let us assume a conservative estimate for the 
entire host at one hundred twenty ships in order to account for its absorption of previously defeated, but returning plunderers before their arrival on English shores in AD $865^{244}$

After this point in the chronicle the majority of the references made to the invaders are listed as, "the force," so we must end our calculation regarding the formation of the Danelaw here because we have little indication of new ships entering the fray. One of the two potential exceptions to this rule is that in AD 871 Alfred defeated a "great summer host." The chroniclers use of the term "summer host" indicates that the English were well aware that there was a difference between a marauding force and an invading one. However, once again the quantifier "great" has no immediate reference with which to compare it against so it must be counted as only one. The second potential exception occurred in AD 875. Alfred met and defeated seven ship companies at sea. However, since there is no indication whether or not this group was a faction of the greater force or a completely new force, their number will not be included in the calculation. This provides a grand total of four hundred eighty-four shiploads of men who participated in the second phase of assaults on England.

However, this does not end the discussion of the events at hand. The next phase in the establishment of the Danelaw exhibits a further extension of the themes represented in the first two. Personal, social, and political motives were all at work during this time. Although the Danelaw had been effectively established by the time of Halfdan's reign at York in AD 876, the turmoil within England was far from over. During the rest of the ninth century, mercenaries continued to plunder, powerful men

\footnotetext{
${ }^{244}$ In addition, it is also quite possible, however unlikely, that Halfdan allowed Basecg, the other commander, to use all of the ships since he was planning on settling down in York.
} 
within the Danelaw continued to struggle for control, and migrants as well as settling warriors continued the search for land.

Two additional factors would help propagate Viking expansion during this later phase as well. The first was Harald Finehair's subjugation of Norway. His use of “join or die" tactics would further entice people such as Ketil Flatnose to leave their lands at home rather than face his tyranny. The second was a factor that has existed throughout all of the three periods under observation, but would greatly increase once a Scandinavian presence was firmly established on English soil. That factor was trade. Although the total number should not be counted to high, what with the possibility that mercantile vessels of any origin in English waters could and probably were seized by the marauders, it is most certain that trading vessels from Scandinavia interacted with the English during this time. Take, for instance, the appearance of Othere in Alfred's court. At some point during Alfred's reign, which lasted from AD 871 to 899, Othere journeyed to England to ply his wares. The high levels of piratical activity would have slowed, but not halted the flow of trade between countries, especially during periods when the troops had moved inland or during the sometimes decade long hiatus between successive raids.

The calculation, however, is unable to incorporate these later events due not only to the lack of evidence provided in the sources, but also because it was designed to give a total only for the establishment of the Danelaw. The total, then, of the first and second phases of this overview is six hundred twenty seven shiploads of men. Although this figure contains a great deal of supposition, its calculation has been very conservative and is only provided as a means to yield an approximation. 
Now we must determine how many men the ships could carry. The upper limit for determining the carrying capacity of Viking ships is drawn from the work of Brogger and Shetlig. ${ }^{245}$ According to their research, the largest class of Viking warship had over thirty rooms, or thirty oars and seats per side, for a total of sixty oars or more. These giant ships, however, were not constructed until well after this period of study, the first being Olaf Tryggvason's Crane circa AD 995. The second class of ships had approximately twenty-five rooms while the smallest class of ships used in warfare had around twenty rooms. Once again for the sake of argument, we should use the smallest class available here in order to keep the calculation on the smaller side and therefore avoid the risk of inflating the results. In order to man each ship fully, each room required from six to sixteen crewmen. ${ }^{246}$ From one hundred twenty men to three hundred twenty men were aboard each ship.

These figures seem askew because it would be impractical to house this number of warriors, their arms and armor, and the necessary military provisions on a boat that was only twenty-eight meters long even if smaller cargo vessels followed in the fleet's wake to carry sundry requirements. However, according to "Saint Olaf's Saga," a thirtytwo bench ship held well over two hundred men. ${ }^{247}$ This works out to be just over six men per room, a figure that is congruent with Brogger and Shetlig's findings. By multiplying the lesser number of crewmen per ship (120) by the number of ships involved in the venture (627), we see that over seventy-five thousand men participated in the formation of the Danelaw. Although conservatively estimated, this figure appears inflated for such a small span of time.

\footnotetext{
245 Brogger and Shetlig, The Viking Ships, 184-223.

${ }^{246}$ Brogger and Shetlig, The Viking Ships, 227.

${ }^{247}$ Sturluson, "Saint Olaf's Saga," ch. 22.
} 
Jones's technique yields a lower number. Using the Gokstad ship as his model, which is twenty-six meters long, Jones presumes that a standard, sixteen room Viking ship of this class could carry between thirty-two and thirty-five sailors. ${ }^{248}$ These figures appear more manageable, but they do not allow for much rotation in inland rowing duties, since there would be only one man per oar, nor do they allow an armed force to be ready to depart the ship when it landed because all of the men would be maneuvering the boat. However, this estimate is corroborated by Leif Eirikson's journey to Vinland when he loaded thirty-five men aboard his ship. ${ }^{249}$ Based on the lesser of his estimates (32), just over twenty thousand Vikings sailed from Scandinavia to England in the forty-one year period covered by this calculation. Therefore, anywhere from seventy-five thousand to twenty thousand men participated in the establishment of the Danelaw in England from AD 835-876. In all actuality, the answer most probably lies somewhere in between. However, further analysis can narrow this wide margin down.

The differences between the methods of calculation are quite apparent. Brogger and Shetlig's technique uses a slightly larger ship and accounts for the rotation of rowing duties. The primary source in reference to it specifically related the filling a ship for war, which is what the men who participated in the English raids would have done. Jones' approach relies upon smaller ships, which was probably more realistic, but assumes that when the sail was down every man on board would be involved in propelling the ship. The primary source concerning his calculations relies upon manning a ship for exploration and colonization. All of the ships that came to England that are mentioned during this forty-one year period were ships of war, so the numbers of men on board were

\footnotetext{
${ }^{248}$ Jones, History of the Vikings, 194.

249 "The Greenlanders Saga," ch. 2.
} 
probably closer to Brogger and Shetlig's estimations than Jones's. Brogger and Shetlig's technique appears to have a more stable foundation for the purposes of the calculation.

In addition, there were many other factors of expansion that could not be included in this figure. For instance, the only records available to historians which speak of quantity are based strictly on Scandinavian ships that participated in violent action. It tells nothing about the number of men who might have journeyed to England on mercantile ventures or specifically for non-violent migration. This calculation also ignores the number of migrants who, after a loved one had settled down on a piece of land taken in conquest by violent action, joined him along with all of their kin. Lastly, the calculation applied the least extreme in every instance which an estimation of size was necessary, whether dealing with the number of ships that participated in a raid or the number of men per boat. Keeping all of these additional factors in mind, a plausible estimation of the number of Scandinavians who traveled to England during the establishment of the Danelaw from AD 835 through 876 increasingly appears to approach the seventy-five thousand mark.

It is important to remember that these figures only represent Viking expansion on the English front. Activity in England mirrored events in Carolingia as well as along the Russian river system. Economic factors such as trade and mercenary work, political factors like conquest and exile, and social factors such as outlawry and inheritance disputes, to name but a few, helped bring such a great volume of Northmen to these areas. These motives for expansion were vibrant within all of Scandinavian lands and it is their combination which led to such a sudden and perpetual thrust of Norsemen into the surrounding world. 


\section{Chapter Four: The Waning of Viking Expansion}

The Viking Age was a time of tremendous change. The Scandinavians lived far too early to be considered part of the merchant middle class that evolved during the late medieval era as evidenced by the formation of guilds, yet they lived far too late to be included with the barbarians of the early medieval world. They are truly the middle children of history in the sense that they are a bridge between these two distinctly different worlds. On one hand, the Vikings were capable of brutal slaughter and destruction solely for personal gain. On the other, they provided a much-needed service that helped to link societies together both economically and culturally. For nearly three hundred years the Norse either participated with or terrified much of the Christian world. It is through these activities that Scandinavian expansion occurred. The question remains, however, as to why this expansion stopped. One of the obvious answers to this question is that invaded lands were able to halt their progress by employing successful defensive projects like bridge building and the construction of defended burhs. Another explanation could be the introduction of Christianity into the ruling families of Scandinavia. However, another explanation for waning expansion exists within the borders of Scandinavia itself. 
Internally, the Vikings would have to come to grips with great change. Kings realized that in order to extend their influence over a much broader area, some mechanism needed to be erected in which to control their subjects and solidify their rule. Originally, ambitious leaders kept their subjects in line personally by traveling the land with their comitatus quelling rebellions and distributing punishment as they went. They established themselves in a central location in order to be able to quickly reach all of the points within their realm. Hakon the Good did this when he assumed control of Norway after he deposed his brother Eirik Bloodaxe..$^{250}$ In this way, if Eirik's forces returned, or if any loyal to Eirik rose up against him, Hakon was in a position to respond to the threat in less time. As Raymond Van Dam has suggested, local authority was best guaranteed by a local presence. ${ }^{251}$ However, as leaders' influence grew to encompass more territory, it was impossible for them to effectively police all of the regions within their control. As Scandinavian society made more and more contact with the outside world, their rulers tried to emulate the more organized system of feudal relations that they had witnessed in the Christian world.

This period of transformation for the Vikings greatly resembled the transformation of Western Christendom which had occurred just a few hundred years before. Van Dam stated in his study of late antique Gaul that local leaders who were removed socially, geographically, or culturally from the centralized power structure provided justice and security for their constituents. ${ }^{252}$ This is the exact same function that local Viking chieftains provided for the people of their districts, separated as they were

\footnotetext{
${ }^{250}$ Sturluson, "The Saga of Hakon the Good," ch. 6.

${ }^{251}$ Raymond Van Dam, Leadership and Community in Late Antique Gaul (Los Angeles: University of California Press, 1985), 8.

${ }^{252}$ Van Dam, Leadership and Community, 19.
} 
from other regions by fjords, mountains, and kinship ties. The difference is that the Carolingians endured these growing pains from the sixth to the ninth centuries while the Scandinavians suffered them from the ninth to the eleventh centuries. In regards to the Carolingians, Pierre Riche stated, “....after the sixth century men actively sought to overcome hardships by placing themselves in the service of their betters."253 This system of vassalage provided men with security in return for service. However, the result of these political, economic, social, and military conglomerations was that multiple autonomous chiefdoms arose which created a fragmented political structure where people placed their trust in the local power broker and not the regional one. Powerful, wealthy lords received men into their household in return for military service to the lord. This arrangement greatly resembles the comitatus of the Scandinavian lands which was in effect during the beginning of the Viking Age, circa AD 800.

Riche stated that eventually, "Charles Martel had arrested this process and assembled under a central power nearly every region in the west." ${ }^{254}$ Charles did not stop this fragmentation by abandoning vassalage though. He did so by modifying it. As Marc Bloch estimates, rulers of this time, "had to choose between two methods of rewarding services. Either he could keep the vassal in his own house and feed, clothe, and equip him at his own expense, or he could endow him with an estate or a regular income derived from land and leave him to provide for his own maintenance." ${ }^{255}$ Instead of just housing their military retainers, rulers began giving them territory to keep in the King's stead. Charles and those who followed his example granted land (the fief or beneficium)

\footnotetext{
${ }^{253}$ Pierre Riche, The Carolingians (Philadelphia: University of Pennsylvania Press, 1993), 37.

${ }^{254}$ Riche, The Carolingians, 50.

${ }^{255}$ Marc Bloch, Feudal Society, trans. L.A. Manyon (Chicago: The University of Chicago Press, 1961), 163
} 
to powerful men who in return supplied military service for their lord and provided him with the rewards that were gained from working the land. Bloch continued by stating that over time the king required his principal vassals to maintain a prescribed number of fighters for the king's disposal. ${ }^{256}$ This unified the separate regions under the control of one man or family who then earned the majority of the wealth from the land, but was also responsible for protecting the entirety of it as well.

The Carolingian world was at this stage of development when it first encountered the Vikings. Previous scholars have shown that, "for the most of Europe in the eighth and ninth century it was the Franks who were the Vikings." ${ }^{257}$ It is during this time when the political configuration most widely used in the Frankish kingdoms was household vassalage and the Franks were the ones who raided their neighbors' lands and plundered their wealth. The annexation of Aquitaine attests to this. As previously argued within this paper, ${ }^{258}$ in order to keep an armed group of warriors happy and loyal, rulers needed to acquire wealth which they could then share with their soldiers. Therefore, as time went on and landed vassalage replaced housed vassalage, which in turn unified the surrounding regions into one cohesive political structure, the magnitude and frequency of Frankish raids decreased. Eventually, instead of simply raiding for wealth, they would find other more political reasons to justify their ravaging, but it was sponsored by the supreme king and not by independent chieftains. Take for example the internal wars within the Carolingian Empire during the ninth century or the continued attacks on Saxony. The Vikings were simply latecomers to this game. However, their transformation greatly resembles the proceedings of the Carolingian transformation.

\footnotetext{
${ }^{256}$ Bloch, Feudal Society, 170.

${ }^{257}$ Reuter, "Tribute and Plunder," 91.

${ }^{258}$ See previous, 64, 92-95.
} 
Unfortunately for historians, the Carolingian annals reflect little upon how the Danes controlled their territory besides what families were ruling, who their opposition was, and who had converted to Christianity. We must look to the sagas to provide information on the feudal relations that existed in Scandinavia. The first indication of landed vassalage occurs in the "Saga of Halfdan the Black." Upon trying to consolidate the chiefdoms in Norway (died c. AD 880), Halfdan set his friend Atle Mjove as earl over the Sogn district in order to, "speak judgment according to the laws of the land and to collect the taxes for the king." ${ }^{259}$ Afterwards, Halfdan returned to the seat of his kingdom in the Uplands.

Although Viking raiding began in the late eighth century (c. 790's), Viking rulers did not utilize landed vassalage to any great extent to control regions that they had newly acquired, but were geographically removed from their base of power, until the reign of Harald Finehair (c. AD 880-930). His saga states,

"Wherever King Harald gained power he made it the law that all ancestral lands (udal) and possessions belonged to him; also, that all farmers had to pay a tax to him, both the great and the humble. He appointed an earl for every district, whose duty it was to administer the law and justice and to collect fines and taxes. And the earl was to have a third of the taxes and penalties for his maintenance and other expenses. Every earl was to have under him four or more hersar, and every hersir was to have twenty marks of revenue. Every earl was to furnish the king sixty soldiers for his army, and every hersir, twenty. But King Harald increased imposts and taxes to such an extent that his earls had greater power than the kings had had before. When this was learned in the Trondheim districts, many men of influence joined the king and became his followers." 260

The indication here is that once Harald conquered a separate kingdom, all of the land within it belonged to him. He then placed an earl in charge of the land to judge legal

\footnotetext{
${ }^{259}$ Snorri, Sturluson, "The Saga of Halfdan the Black," Heimskringla: History of the Kings of Norway, trans. Lee M. Hollander (Austin: University of Texas Press, 1964), ch. 3.

260 Sturluson, "The Saga of Harald Finehair," ch. 6.
} 
matters and collect taxes over its inhabitants. These earls were also responsible for maintaining a militia that the king could call upon in times of need which Bloch stated was the eventual requirement of Carolingian vassals. These earls gained so much money, power, and prestige, that other powerful men sought to join Harald in order to receive the same benefits. Harald even extended this privilege to his own sons, giving them control of various districts under his rule. ${ }^{261}$

However, Harald's initial attempts to unify Norway by granting fiefs did not last. Upon his death, his sons split the land amongst themselves and political infighting began. Later claimants to the throne of Norway would not forget this tactic though and as time progressed, they often attempted to reconstruct it. Harald's son Hakon (ruled AD 936960) made wide use of landed vassalage to the point that he even gave men the earldoms that their fathers had held under Harald, but still restricted their udal rights. ${ }^{262}$ This shows that at this early date some consideration was given to the inheritance of fiefs. In addition, Hakon increased the military requirements for each of his earls requiring that the districts be split up into ship-raths which fixed the numbers of ships that each district must provide for defense of the country from foreign invasion. ${ }^{263}$

After Hakon's death, the resulting division of territory reveals that Denmark was also granting fiefs at this time. Once again, after the king died the inheritor of the title could not maintain control over the separate regions because the earls' loyalties lay elsewhere. Harald Bluetooth of Denmark saw an opportunity in the fragmentation of rule and conquered much of Norway (c. AD 970). Upon completing this conquest, he granted Hakon, who was the son of Sigurd, one of King Hakon the Good's former dispossessed

\footnotetext{
${ }^{261}$ Sturluson, "The Saga of Harald Finehair," ch. 33.

${ }^{262}$ Sturluson, "The Saga of Hakon the Good," ch. 6, 9, and 10.

${ }^{263}$ Sturluson, "The Saga of Hakon the Good," ch. 20.
} 
and murdered earls, seven districts to rule over with the exception that Hakon did not have to pay tax to Harald. ${ }^{264}$ He was to use this money to protect the realm and to try to conquer more of it. He also gave Harald Grenske and Eirik kingdoms within his Norwegian dominions on the stipulation that they followed the same regulations and paid the same taxes that Harald Finehair established years before. ${ }^{265}$ A centralized ruler, this time in Denmark, had exerted control over newly acquired lands by granting men property to govern in the king's stead.

This process, that of political infighting resulting in the fragmentation of once unified territories, would continue well into the eleventh century. However, as the populace gradually accepted the concept of a united kingdom, for it was they who decided whether or not support with arms either the king or a pretender, these succession disputes eased. By the time Harald Hardrada came to power in AD 1045, royal control of the warrior aristocracy was commonplace and nearly complete It had taken some time to accomplish this, though. As early as AD 847, the Carolingians fully expected Danish rulers to be in control of all of the inhabitants that the Danes claimed were under their control. $^{266}$

However, once Scandinavian leaders strengthened their rule by transforming their own society into one that reflected the feudal relationships they had witnessed of the Christian world, the tendency towards expansion diminished. Their newly adopted Christianity helped to prevent them from attacking their Christian neighbors. Kings who had managed to successfully unite the countries which would later become known as Norway, Denmark, and Sweden, were now, in theory if not in practice, under direct

\footnotetext{
${ }^{264}$ Sturluson, "The Saga of Olaf Tryggvason," ch. 15.

${ }^{265}$ Sturluson, "The Saga of Olaf Tryggvason," ch. 15 and 20.

${ }^{266}$ Annals of St. Bertin, year 847.
} 
control of the organization of men and equipment for military purposes. It is likely that they would frown upon and work against the proliferation of warriors without royal consent because their desires would not necessarily be reflected in the army's purpose. An army of men not under royal control could easily be a revolutionary force. In addition, foreign countries expected kings to be able to control their own inhabitants because actions taken by freebooting pirates could easily be mistaken for acts of war between countries. These private expeditions also furnished a living for potential rivals to the throne and allowed exiles the means to fund and man future coup attempts.

At the onset of the Viking Age, the interaction between the loosely knit warrior aristocracies that reigned in Scandinavia was the cause of a great deal of expansion. This structure needed the continual input of wealth in order to maintain itself. The resultant raids were a means in which rulers could satiate their current demand for power and wealth and gain the prestige and backing to further unite more regions under their control. Struggles for power resulted in exiles and outlaws being cast out of Scandinavia in order to search for a new life abroad. By the close of the Viking Age, the adoption of Christianity and feudalism would all but halt the intriguing phenomena that resulted in the sudden and prolific expansion of Scandinavian people into the surrounding world. Nevertheless, during its time Viking expansion was the cause of a multitude of changes in the medieval world that we are only now becoming able to truthfully understand. 


\section{Bibliography}

\section{Primary Sources}

The Anglo-Saxon Chronicle, trans. G.N. Garmonsway (New York: Dutton, 1965)

The Anglo-Saxon Chronicle, trans. Anne Savage (New York: St. Martins, 1983)

Annals of Fulda, trans. Timothy Reuter (New York: Manchester University Press, 1992)

Annals of St. Bertin, trans. Janet L. Nelson (Manchester, England: Manchester University Press, 1991)

Anskar: the Apostle of the North, 801-865, Saint Rimbert, trans. Charles H. Robinson, D.D. (London: The Society for the Propagation of the Gospel in Foreign Parts, 1921)

The Chronicle of Aethelweard, trans. A. Campbell (London: Thomas Nelson and Sons, Ltd., 1962)

The Complete Sagas of Icelanders, vol. 1, "Eirik the Red's Saga," (Reykjavik: Leifur Eiriksson Publishing, 1997)

The Complete Sagas of Icelanders, vol. 1, "The Saga of the Greenlanders," (Reykjavik: Leifur Eiriksson Publishing, 1997)

The Complete Sagas of Icelanders, vol. II, “The Saga of Grettir the Strong," ed. Vidar Hreinsson, (Reykjavik, Iceland: Leifur Eiriksson Publishing, 1997)

Ecclesiastical History of the English People, Bede, edited by Bertram Colgrave and R.A.B. Mynors (Oxford: Clarendon Press, 1969)

Heimskringla: The History of the Kings of Norway, "King Olaf Trygvason's Saga," Snorri Sturluson, trans. Samuel Laing, May 1996, http://sunsite.berkeley.edu/OMACL/Heimskringla/, (18 April 2002)

Heimskringla: King Harald's Saga, Snorri Sturluson, trans. Magnus Magnusson and Hermann Palsson (NY: Penguin Books, 1966)

Heimskringla: History of the Kings of Norway, Snorri Sturluson, trans. Lee M. Hollander (Austin: University of Texas Press, 1964)

-"The Saga of Hakon the Good"

-"The Saga of Halfdan the Black"

-"The Saga of Harald Finehair"

-"The Saga of Harald Graycloak"

-"The Saga of Olaf Tryvagson"

-"Saint Olaf's Saga" 
The Old English Orosius, ed. Janet Bately (London: Oxford University Press, 1980)

Laxdaela Saga, trans. Margaret A. Arent (Seattle, University of Washington Press, 1964)

Royal Frankish Annals, from Carolingian Chronicles, trans. Bernhard Walter Scholz (Ann Arbor: University of Michigan Press, 1970)

The Russian Primary Chronicle: Laurentian Text. trans. and ed. Samuel Hazzard Cross and Olgerd P. Sherbowitz-Wetzor (Cambridge, The Medieval Academy of America, 1953)

The Sagas of Icelanders, "Egil's Saga," ed. Ornolfur Thorsson, (New York: Viking Penguin, 2000)

\section{Secondary Sources}

Ambrosiani, Bjorn, "Ireland and Scandinavia in the Early Viking Age: an Archaeological Response," Ireland and Scandinavia in the Early Viking Age (Blackrock: Four Courts Press, 1998), 405-420

Ambrosiani, Bjorn, "Specialization and Urbanization in the Malaren Valley - a question of maturity," Society and Trade in the Baltic during the Viking Age, ed. Sven-Olaf Lindquist (Visby: Gotlands Fornsal, 1985), 103-113

Anderson, Per Sveaas, Expansion of Norway in the early Middle Ages (Oslo: Tanum, 1971)

Barnes, Geraldine, "The Medieval Anglophile - England and its Rulers in Old-Norse History," Parergon 10, no. 2 (Dec 1992), 11-25

Benedictow, Ole Jorgen, "The Demography of the Viking Age and the High Middle Ages in the Nordic Countries," Scandinavian Journal of History 21, no. 3 (1996), 151-182

Bentley, Jerry H., Old World Encounters (NY: Oxford University Press, 1993)

Bloch, Marc, Feudal Society, trans. L.A. Manyon (Chicago: The University of Chicago Press, 1961)

Blondal, Sigfus, The Varangians of Byzantium (Cambridge: Cambridge University Press, 1978)

Brogger, Anton W. and Shetelig, Haakon, The Viking Ships: Their Ancestry and Evolution (Oslo: Dreyers, 1951) 
Christensen, Arne Emil, "Ships and Navigation," in Vikings: The North Atlantic Saga (Washington: Smithsonian Institution Press, 2000), 86-97

Clarke, Helen, "English and Baltic Trade in the Middle Ages," Society and Trade in the Baltic during the Viking Age. ed. Sven-Olaf Lindquist (Visby: Gotlands Fornsal, 1985), $114-163$

Clarke, Helen, Towns in the Viking Age (New York: St. Martin's Press, 1991)

Cross, Samuel Hazzard and Sherbowitz-Wetzor, Olgerd P., The Russian Primary

Chronicle: Laurentian Text (Cambridge, The Medieval Academy of America, 1953)

Curtin, Philip D., Cross Cultural Trade in World History (NY: Cambridge University Press, 1984)

Cutler, Kenneth, "Danish Exiles in the Carolingian Empire--the Case for Two Haralds," Feb. 11, 2000, http://php.iupui.edu/ kcutler/exiles.html (21 January 2002)

Dahl-Jensen, D., et al., "Past Temperatures Directly from the Greenland Ice Sheet," Science 282, no. 5387 (1998), 268-271

Davidson, Hilda Roderick Ellis, The Viking road to Byzantium (London: George Allen and Unwin Ltd., 1976)

Graham-Campbell, James, "The Early Viking Age in the Irish Sea Area," Ireland and Scandinavia in the Early Viking Age (Portland, OR: Four Courts Press, 1998), 104-130

Hall, Richard, “The Vikings as Town-Dwellers," History Today 36 (Nov. 1986)

Haywood, John, The Penguin Historical Atlas of the Vikings (New York, NY: Penguin Group, 1995)

Helle, Knut, "History of the Early Viking Age in Norway," Ireland and Scandinavia in the Early Viking Age (Blackrock: Four Courts Press, 1998), 239-258

Hodges, Richard, Dark Age Economics: The Origins of Towns and Trade AD 600-1000 (New York: St. Martin's Press, 1982)

Hodges, Richard and Whitehouse, David, Mohammed, Charlemagne, and the Origins of Europe (Ithaca: Cornell University Press, 1983)

Hodges, Richard, “The Not-So-Dark Ages,” Archaeology 51, no. 5 (Sept-Oct 1998), 6165

Jones, Gwyn, History of the Vikings (New York: Oxford University Press, 1984) 
Jones, S.R.H., "Transaction Costs, Institutional Change, and the Emergence of a Market Economy in later Anglo-Saxon England," Economic History Review 46, no. 4 (1993), 658-678

Kellogg, Robert, The Sagas of Icelanders, ed. Ornolfur Thorsson (New York: Viking Penguin, 2000)

Kromann, Anne and Jensen, Jorgen Steen, "Cufic coins in Denmark," Byzantium and Islam in Scandinavia: Acts of a Symposium at Uppsala University, June 15-16, 1996, ed. Elisabeth Piltz (Jonsered: Paul Astroms Forlag, 1998), 72-86

Lamb, H. H., "The Early Medieval Warm Epoch and its Sequel," Paleogeography. Paleoclimatology. Paleoecology. Vol. 1, no. 13 (1965), 13-37

Larson, Laurence, "The Political Policies of Cnut as King of England," The American Historical Review 15, no. 4 (Jul., 1910), 720-743

Logan, F. Donald, The Vikings in History (New York: Routledge, 1992)

Lund, Neils, "Allies of God or Man - The Viking Expansion in a European Perspective," Viator-Medieval and Renaissance Studies 20 (1989), 45-59

Magnusson, Magnus and Palsson, Hermann, King Harald's Saga: Harald Hardradi of Norway (NY: Penguin Books, 1966)

Magnusson, Magnus, Viking Expansion Westward (New York: H. Z. Walck, 1973)

McGovern, Thomas H., The Archaeology of the Norse North Atlantic. Annual Review of Anthropology 19 (1990), 331-351

Myhre, Bjorn, "The Archaeology of the Early Viking Age in Norway," in Ireland and Scandinavia in the Early Viking Age (Dublin, Ireland: Four Courts Press, 1998), 3-36

Nasman, Arhus Ulf, "Vendel Period Glass from Eketorp II, Oland, Sweden," Acta Archaeologica 55 (1984), 56-116

Nelson, Janet L., The Annals of St. Bertin, vol. 1 of Ninth Century Histories (NY: Manchester University Press, 1991)

Noonan, Thomas S., "Why the Vikings First Came to Russia," Jahrbucher Fur Geschichte Osteuropas 34, no. 3 (1986), 321-348

O'Floinn, Raghnall, "The Archaeology of the Early Viking Age in Ireland," Ireland and Scandinavia in the Early Viking Age, (Blackrock: Four Courts Press, 1998), 131-165 
Piltz, Elisabeth, "Byzantium and Islam in Scandinavia," Byzantium and Islam in Scandinavia: Acts of a Symposium at Uppsala University, June 15-16, 1996, ed. Elisabeth Piltz (Jonsered: Paul Astroms Forlag, 1998)

Piltz, Elisabeth, "Varangian Companies for Long Distance Trade," Byzantium and Islam in Scandinavia: Acts of a Symposium at Uppsala University, June 15-16, 1996, ed. Elisabeth Piltz (Jonsered: Paul Astroms Forlag, 1998), 87-106

Pirenne, Henri, Mohammed and Charlemagne (New York: Barnes and Noble, Inc., 1955)

Olafsson, Haraldur, "Sagas of Western Expansion," in Vikings: The North Atlantic Saga (Washington: Smithsonian Institution Press, 2000), 142-145

Randsborg, Klaus, "Barbarians, Classical Antiquity, and the Rise of Western Europe: an Archaeological Essay," Past and Present, no. 137 (Nov. 1992), 8-24

Randsborg, Klaus, "The Demise of Antiquity: Europe and the Mediterranean in the First Millennium AD," Annual Review of Anthropology 18, (1989), 227-244

Reuter, Timothy, "Plunder and Tribute in the Carolingian Empire," Transactions of the Royal Historical Society, $5^{\text {th }}$ series, 35 (1985), 75-94

Riche, Pierre, The Carolingians (Philadelphia: University of Pennsylvania Press, 1993)

Savage, Anne, The Anglo-Saxon Chronicle, (New York: St. Martins, 1983)

Sawyer, Peter, "Birka, the Baltic, and Beyond," Society and Trade in the Baltic during the Viking Age. ed. Sven-Olaf Lindquist (Visby: Gotlands Fornsal, 1985), 165-202

Sawyer, Peter, "Scandinavia in the Viking Age," in Vikings: The North Atlantic Saga (Washington: Smithsonian Institution Press, 2000), 27-30

Scholz, Bernhard Walter, Carolingian Chronicles (Ann Arbor: University of Michigan Press, 1970)

Sheehan, John, "Early Viking Age Silver Hoards from Ireland and their Scandinavian Elements," Ireland and Scandinavia in the Early Viking Age, (Blackrock: Four Courts Press, 1998), 166-202

Skre, Dagfinn, "New excavations of Kaupang, a Viking Age Port of Trade." n.d. $<$ http://www.kaupang.uio.no/Engelsk_hovedside.htm> (April 3, 2000)

Smith, Kevin P., "Landnam: the settlement of Iceland in archaeological and historical perspective," World Archaeology 26, no. 3 (Feb. 1995), 319-347 
Stein-Wilkeshuis, Martina, "Legal Prescriptions on Manslaughter and Injury in a Viking Age Treaty Between Constantinople and Northern Merchants," Scandinavian Journal of History 19, no. 1 (1994), 1-16

Ulriksen, Jens, "Danish sites and Settlements with a Maritime Context, AD 200-1200," Antiquity 68, no. 261 (Dec. 1994), 797-811

Valante, Mary A., "Reassessing the Irish Monastic Town," Irish Historical Studies 31, no. 121 (May 1998), 1-18

Van Dam, Raymond, Leadership and Community in Late Antique Gaul (Los Angeles: University of California Press, 1985)

Walsh, Aidan, "A Summary Classification of Viking Age Swords in Ireland," Ireland and Scandinavia in the Early Viking Age, (Blackrock: Four Courts Press, 1998), 222-235

Wamers, Egon, "Insular Finds in Viking Age Scandinavia and the State Formation of Norway, "Ireland and Scandinavia in the Early Viking Age, (Blackrock: Four Courts Press, 1998), 37-72

White, Lynn, Jr., Medieval Technology and Social Change (New York: Oxford University Press, 1976)

Wilson, David M., The Vikings and Their Origins (New York: Thames and Hudson, Inc., 1989) 


\section{Darrin M. Cox}

419 Fairmont Rd.

Westover, WV 26501

wvorn@yahoo.com

304-292-8333

\section{$\underline{\text { Education }}$}

MA in History, May 2002

Major: Medieval History

West Virginia University, Morgantown, WV

BS in Journalism, December 1997

Major: News/Editorial Writing

West Virginia University, Morgantown, WV

\section{$\underline{\text { Languages }}$}

Fluent in: English, Classical Latin, and Medieval Latin

Research experience in: Old English and Spanish

\section{$\underline{\text { Awards }}$}

Dennis H. O'Brien Graduate Student Award

Anna Traubert Fellowship

Dean's List Recipient

\section{Professional Experience}

Teaching Assistant, Spring 2002

Department of Women Studies, West Virginia University

Course: Introduction to Women Studies

Duties: Sole instructor for two sections of WMST 170

Teaching Assistant, Fall 2001

Department of Women Studies, West Virginia University

Course: Introduction to Women Studies

Duties: One of four instructors that team-taught eight sections of WMST 170, discussion leader and grader for two course sections.

Instructor/Supervisor, July 2000-August 2000

Governor's Summer Youth Program, Morgantown, WV

Duties: Afternoon instructor/morning work supervisor for disadvantaged youths 
Undergraduate Student Records Assistant, August 1999-May 2000

College of Engineering and Mineral Resources, West Virginia University

Duties: Advise students, maintain Dean's files (over 2000 students), produce specialized reports for advising assistance, process student requests (transfers, D/F repeats, major changes, etc...), and serve as the clerk for the Academic Standards Committee

\section{$\underline{\text { Professional Memberships }}$}

Phi Alpha Theta, Delta Nu Chapter

West Virginia University History Club

-Historian, 2001-2002

\section{Professional Activities}

Teaching Horizons Workshop

-offered at WVU, Fall 2001

Teaching Assistants Workshop -offered at WVU, Fall 2001

\section{$\underline{\text { References }}$}

Dr. Stephen McCluskey, Professor

Department of History, WVU

P.O. Box 6303

Morgantown, WV 26505

304-293-2421

Dr. Matthew Vester, Professor

Department of History, WVU

P.O. Box 6303

Morgantown, WV 26505

304-293-2421

Alice Frost, Lecturer

Department of Foreign Languages

421 Eiesland Hall, P.O. Box 6298

Morgantown, WV 26505

304-293-3604

Dr. Afzel Noore, Associate Dean for Academic Affairs

College of Engineering and Mineral Resources

P.O. Box 6101

Morgantown, WV 26506

304-293-4821 